Portland State University

PDXScholar

1984

\title{
A history of the street railway systems of Vancouver, Washington, 1889-1926
}

David Warren Freece

Portland State University

Follow this and additional works at: https://pdxscholar.library.pdx.edu/open_access_etds

Part of the History Commons, and the Urban Studies and Planning Commons Let us know how access to this document benefits you.

\section{Recommended Citation}

Freece, David Warren, "A history of the street railway systems of Vancouver, Washington, 1889-1926" (1984). Dissertations and Theses. Paper 3439.

https://doi.org/10.15760/etd.5322

This Thesis is brought to you for free and open access. It has been accepted for inclusion in Dissertations and Theses by an authorized administrator of PDXScholar. Please contact us if we can make this document more accessible: pdxscholar@pdx.edu. 
AN ABSTRACT OF THE THESIS OF David Warren Freece for the Master of Arts in History presented June 20, 1984.

Title: A History of the Street Railway Systems of Vancouver, Washington, 1889-1926.

APPROVED BY MEMBERS OF THE THESIS COMMITTEE:

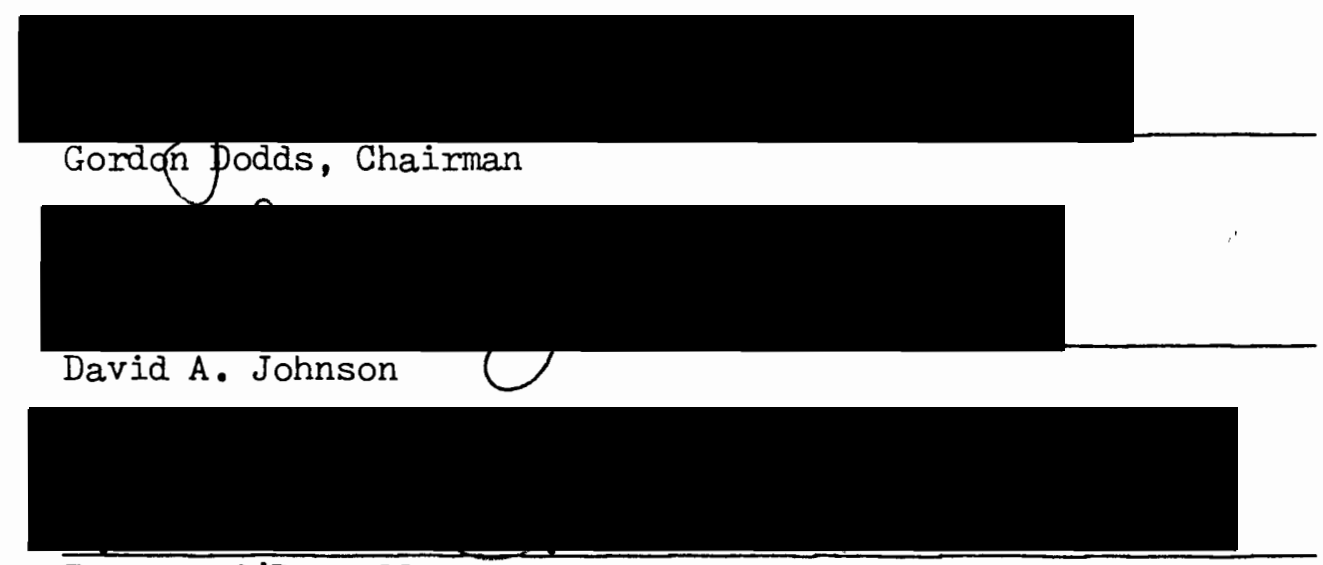

Terence O'Donnell

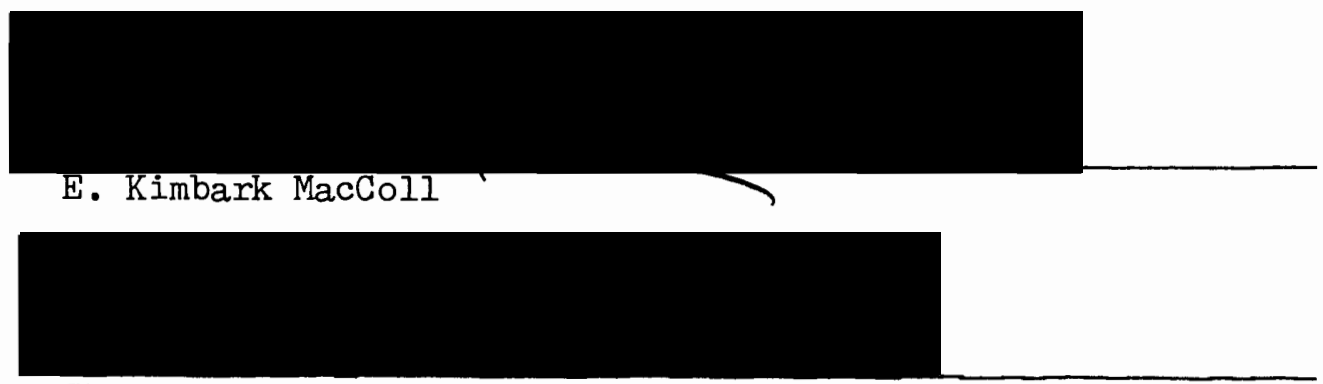

Sheldon Edner

The decade of the 1880 s was a time of unprecedented development in the Pacific Northwest. Railroads were being constructed, immigration was high, lumber in demand and statehood for Washington appeared imminent. Vancouver, Washington, benefited from this prosperity. In 1888 a 
Portland firm built a steam powered railway from East Portland, through its real estate development, Woodlawn, to the Vancouver ferry. The success of this enterprise in aiding the sale of real estate was observed by several Vancouver men who formed the Columbia Land and Improvement Company to promote the sale of their property. The company constructed a horse drawn street railway in 1889 from Vancouver's business district north to its development in Vancouver Heights. The railway had mixed financial success and was sold to a Portland man, George B. Markle, in 1892. He electrified it and operated the line until his financial empire crumbled in the Panic of 1893. After several years of operation in the hands of a receiver, the railway ceased running in 1895, and was dismantled two years later.

With the announcement that James $\mathrm{J}$. Hill was going to build the Spokane, Portland and Seattle Railway through Vancouver in 1895, the area's prosperity was renewed. A number of franchise seekers vied for the opportunity to build a street railway in Vancouver, and in 1906 Walter H. Moore was granted permission. Before the line's construction was completed, Moore went bankrupt in the recession of 1907. A group of Vancouver men took over building it until 1908 when the Vancouver Traction Company was formed. This firm completed the line and operation commenced that year. In 1910 a subsidiary, the Clarke County Development Company was incorporated to build an interurban line east of town to Orchards and Sifton, an area in which they had real estate interests. The system did not pay as the investors had hoped, and in 1911 it was sold to the Washington - Oregon Corporation, a utility holding company. It managed the line until forced into receivership in 1914. In the fall 
of 1915 the company was reorganized under the name of the North Coast Power Company.

During the next eight years the expense of operating the line increased rapidly with the wartime inflation of labor and materials. The line had been cheaply constructed and was in need of major overhauling. Jitneys, buses, and automobiles were providing increasing competition, but this was somewhat abated by the shipyard workers need for transportation. In 1920 the line reached its highest ridership, serving over one million passengers that year. It dropped off rapidly thereafter, and in 1923 the system was sold to the Puget Sound Power:and Light Company of Seattle. In spite of several fare increases, the line was still losing money, and in 1926 ceased operation.

The street railway systems of Vancouver were a source of civic pride, and contributed to the development of the town. Had the second system been built earlier and more extensively, its impact would have been greater. As it was, the automobile soon eclipsed its influence. Major sources of information for this study were company records, newspapers, and government documents, particularly the records of the Public Service Commission of the State of Washington. Various books and articles were also consulted. 


\title{
A HISTORY OF THE STREET RAILWAY SYSTEMS OF \\ VANCOUVER, WASHINGTON, 1889-1926
}

\author{
by \\ DAVID WARREN FREECE
}

A thesis submitted in partial fulfillment of the requirements for the degree of

\author{
MASTER OF ARTS \\ in \\ HISTORY
}

Portland State University

1985 
TO THE OFFICE OF GRADUATE STUDIES AND RESEARCH:

The members of the Committee approve the thesis of David Warren Freece presented June 20, 1984.

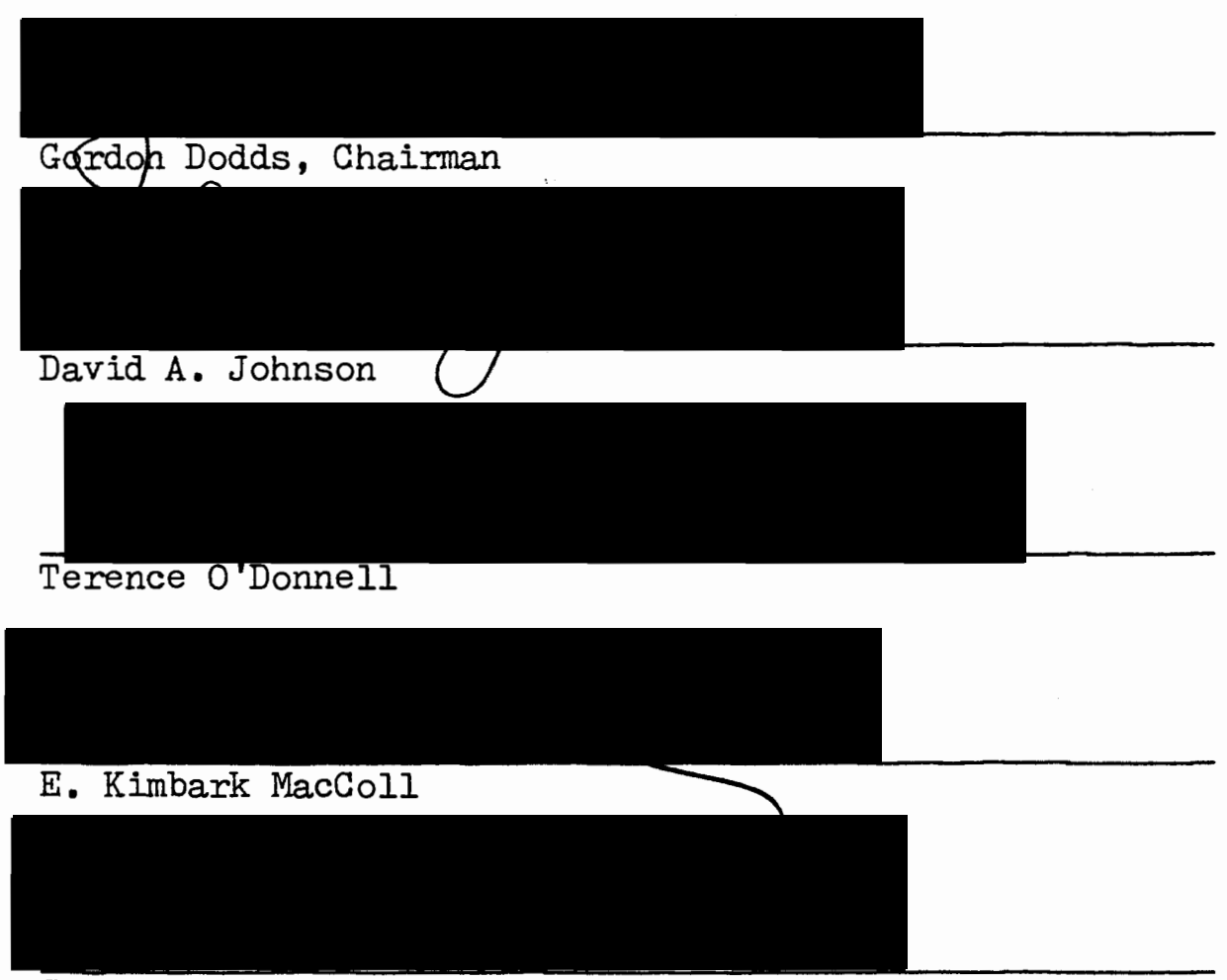

Sheldon Edner
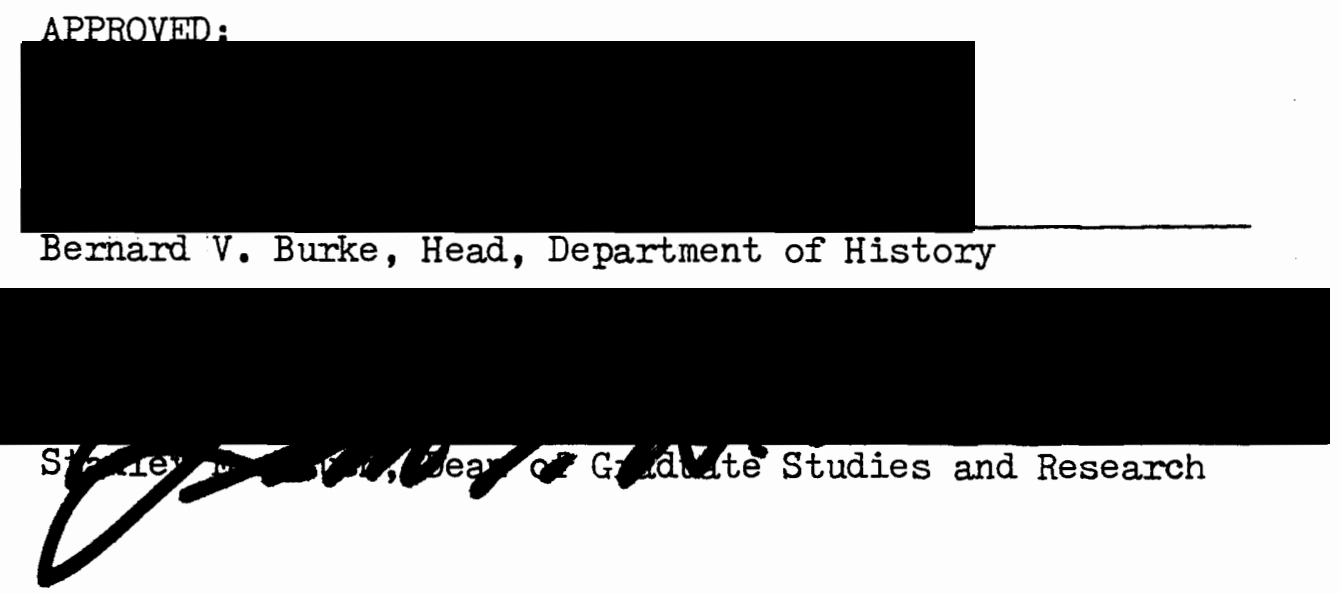


\section{PREFACE}

A major component of Pacific Northwest history is the development of transportation networks. The importance of good harbors or rivers, military roads, plank roads, mosquito fleets, and railroad connections has been declared by historians. But just as the transportation links or networks were significant in the development of the region, transportation improvements within a city or town were important to their growth. The establishment of bridges, ferries, streets, street railway or bus systems has had a stimulating effect upon the communities they served.

Vancouver, Washington, has had two railway systems. The first one, constructed in 1889 as a horse drawn line, was electrified in 1892, and ceased operation in 1895. The later system, built in 1908 after several false starts, was extended east of the city in 1910, and operated under a succession of owners with mixed financial success until 1926. In considering the history of these two systems a number of questions come to mind. Why were they built at those particular times, and what factors influenced the choosing of their routes? What determined their periods of financial success, if any, and what were the factors that ultimately led to their demise? How was Vancouver effected by the street railways? Is it different today as a result of them? In chronicling the history of the street railway systems of Vancouver, I have endeavored to answer these questions. 


\section{ACKNOWLEDGEMENTS}

In researching and writing this work I was assisted by a number of people who deserve recognition for their contributions. Gordon Dodds and David Johnson of my thesis committee helped me define and shape my topic in the early critical stages. Committee members Terence O'Donnell, E. Kimbark MacColl and Sheldon Edner provided useful suggestions and encouragement. David Hastings of the Washington State Archives, Jim Moore of the Center for Pacific Northwest Studies, the 1ibrarians at the Corps of Engineers Library, the reference librarians at the Fort Vancouver Regional Library, and the staff at the University of Washington in the Pacific Northwest Collection and Manuscripts Library, were all very helpful in steering me to sources of information in their collections. Andree Purdom spent several hours looking through some company records for me and thereby saved me from making a second trip to Bellingham. I am also grateful to the clerks in the Clark County Auditor's office, and those at Vancouver's City Hall for their efforts in seeking out old records, and their patience in answering my many questions.

To Steve Cairns goes a hearfelt thanks for the time he took out of his busy schedule to read portions of this paper and offer suggestions concerning the writing style. Bud Cairns also had some much appreciated advice. Rick Edwards and Patti Norberg assisted me with the maps and graphs, and Ed Johnson spent an afternoon in Sifton with me seeking out evidence of the railway line. 
All of the help that I have received pales next to that contributed by my wife. Her encouragement and confidence sustained a weary spirit; her patience, understanding, and sacrifices were beyond the call of duty. It is to Janet that I dedicate this work. 
TABLE OF CONTENTS

PAGE

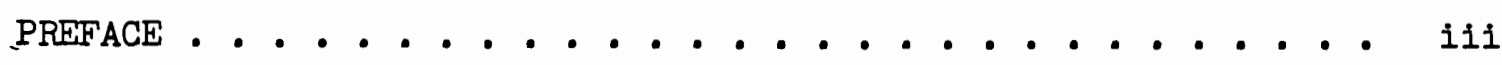

ACKNOWLEDGEMENTS ............................. iv

LIST OF FIGURES .................... . . . viii

CHAPTER

I INTRODUCTION: VANCOUVER IN THE 1880s ....... 1

Notes ................. 10

II THE COLUMBIA LAND AND IMPROVEMENT COMPANY, 1889-1892 13 Notes ............... 30

III CONSOLIDATION AND DECLINE, 1892-1897 ...... 34

Notes .............. 47

IV PROSPERITY AND FRANCHISE SEEKERS: $1905 \ldots \ldots$

Notes ......................... 58

V FRANCHISE GRANTED: $1906 \ldots . . . . . . . . . . . .60$

Notes ................ . . 73

VI THE VANCOUVER TRACTION COMPANY, 1908-1911 .... 77

Notes ................. 94

VII THE WASHINGTON - OREGON CORPORATION, 1911-1915 ... 98

Notes .............. 110

VIII THE NORTH COAST POWER COMPANY, 1915-1923 ..... 112

Notes ............... 131 
IX THE FINAL YEARS, 1923-1926.......... 137 Notes ............. . . 144

X VANCOUVER'S STREET RAIIWAYS: AN ASSESSMENT $\ldots \ldots$ Notes . . . . . . . . . 152

SOURCES CONSULTED . . . . . . . . . . . . . 153 


\section{IIST OF FIGURES}

FIGURE

PAGE

1. Vancouver's first street railway, 1892. . . . . . . . 18

2. Columbia Land and Improvement Company Street Car . . . 19

3. Columbia Land and Improvement Company: Street Railway operating expenses and fare revenues . . . . . . . 26

4. Vancouver's second street railway, city route, 1912 . . 80

5. Vancouver's second street railway, interurban route, ca 1912 . . . . . . . . . . . . . 87

6. Sifton depot, ca 1911-1915 . . . . . . . . . 90

7. Vancouver Traction Company, profits and Iosses, 1908-1911 . 92

8. Profits and losses, 1911-1925 . . . . . . . . . 106

9. Passenger ridership, 1914-1925 . . . . . . . . . 117 


\section{CHAPTER I}

INTRODUCTION: VANCOUVER IN THE 1880s.

The decade of the 1880 s was a period of unprecedented development in the Pacific Northwest. In 1883 the transcontinental railroad through Portland had been completed to Goble, on the Columbia River, opposite Kalama, Washington, and a ferry was provided there for through traffic up the Cowlitz River to Puget Sound. By building a switchback over Stampede Pass in 1887, the Northern Pacific achieved a direct route from Eastern Washington, over the Cascade Mountains, and on into the Puget Sound region. Other lines were also in plan or progress; there were thirty-six railroads either under construction or about to be commenced in Washington Territory in 1889.1

The national publicity the Pacific Northwest received from the building of the transcontinental lines made people more aware of the region's opportunities. Prior to these developments, the number of immigrants had been limited to those who were willing to endure the hardships of the wagon trail, the longer sea voyages around South America or across the Isthmus of Panama, or the crossing by railroad to California and then up the Pacific Coast by ship. ${ }^{2}$ With the completion of the railroads, immigration increased markedly. In 1880 Washington Territory had only 75,116 people. By 1890 it had acquired another $275,000.3$

Besides facilitating transportation to the Pacific Northwest, the railroads also provided employment for the immigrants. They built the 
railroads; logged the rich timber resources for ties, bridges and trestles; and made the lumber for housing the burgeoning population. The improved transportation facilities and national publicity came to the attention of capitalists who subsequently invested in the region, investments which in turn led to more building and an increased demand for lumber. 4

As Washington Territory's population grew in the 1880 s, so did its desire to achieve statehood. Federal appropriations were miserly before statehood as the territory had no voting representative in Congress to secure funds. Land grants, lands designated for schools, and the proceeds from the sale of lands from the public domain were not available until statehood. ${ }^{5}$ In the early years of the decade, both houses of the national Congress were Republican and, since residents of Washington Territory were predominantly of that party too, it seemed likely that the area would finally, after three decades of territorial status, become a state. Then from 1883 until 1888, the Democratic party controlled Congress, and they were not enthusiastic about admitting a state that was apparently Republican. The anti-Chinese riots in the mid-1880s did not add to the territory's attractiveness and, according to one historian, "Many easter Congressmen, too, were afraid to admit a territory where woman suffrage was permitted, as it was in Washington Territory from $1883-1887 . " 6$

With the election of Republican majorities in both houses of Congress and a Republican President, Benjamin Harrison, in 1888, the movement of Washington (and other territories) towards statehood gained momentum. The lame duck Congress produced an omnibus admission bill for 
Washington, the Dakotas and Montana which President Grover Cleveland signed on February 22, 1889. After a constitutional convention in the summer and the resulting voter approval of the constitution, Washington was formally proclaimed a state on the 11 th of November.?

The movement towards statehood and its eventual attainment in the latter years of the decade increased Washington's appeal to immigrants. In the two years between 1887 and 1889 the population increased by 95,000; this gain was more than the total population in Washington Territory in $1880 .^{8}$

Vancouver, Washington, situated 107 miles up the Columbia River on the north bank, experienced this boom in the 1880 s along with the rest of Washington. First settled by the Hudson Bay Company in 1825, and jointly occupied by the United States and Britain until 1846, Vancouver had long been overshadowed by Portland, Oregon, which lay a few miles south of it. Portland had the advantages of a better natural harbor, access to the wheat fields of the Tualatin plains and Willamette Valley, and a group of business men who actively pursued the town's (and their personal) interests. By virtue of being residents of an old state (Oregon had been admitted in 1859), these businessmen were able to wield political power in Congress. For example, they were able to acquire appropriations to have their harbor improved by the Corps of Engineers beginning in 1866; Vancouver would have to wait until 1892 before any federal money was spent on its harbor. ${ }^{9}$ With the movement towards statehood in Washington, the railroad building, and the increasing population demanding goods and services, the Vancouver area grew quickly. In 1880 Vancouver had 1700 people, in $1890,3500 .^{10}$ The corresponding figures 
for Clarke County are 5490 and $11,709 .^{11}$

In 1849 the United States Military established its presence in Vancouver. By the 1880s, many of the log buildings that had been hastiIy erected by the army when it first arrived had deteriorated to the point where replacement was necessary. During the decade sixteen handsome houses were built for the officers stationed there at a total construction cost of about $\$ 100,000 .^{12}$ This row of new houses along the north side of the parade ground gave the Vancouver Barracks a smart appearance and made it an attractive place for the socially prominent to gather.

Vancouver acquired its first railroad during the 1880s. A group of Vancouver businessmen incorporated the Vancouver, Klickitat and Yakima Railroad Company on January $29,1887 .{ }^{13}$ S.W. Brown was president, Charles Brown, secretary, and I.M. Hidden, vice-president. The First National Bank of Vancouver served as treasurer. The directors' goal was to build a line from Vancouver north to the East Fork of the Lewis River, across the Cascade Mountains near Mt. Adams, to the great wheat growing country near Yakima. ${ }^{15}$ Much of the easily accessible timber along the Columbia River had already been logged off, and this road also would provide access to the vast virgin stands to meet the increased demands. ${ }^{16}$ They also believed (erroneously) that there were coal fields and other valuable minerals seventy-five miles northeast of vancouver in an area which had been, up to this time, remote and unexploited. ${ }^{17}$

In spite of its grand plans, the Vancouver, Klickitat and Yakima Railroad Company only completed thirteen and one-half miles (by early 1889) from its lumber mill, the Michigan Mill in Vancouver, to Brush 
Prairie northeast of town. This was all that was to be built until it was acquired by the Portland, Vancouver and Yakima Railway Company ten years later. ${ }^{18}$ The building of the Vancouver, Klickitat and Yakima line of course provided employment for a number of local men as well as attracting more immigrants. The access to the timber which the railroad provided supplied the Michigan Mill with its raw materials to meet the local demand for lumber.

Another development which aided the growth of Vancouver was the improvement of transportation to Portland. Since 1858 there had been a ferry across the Columbia River which connected Vancouver and Portland. A traveler could take a stage across on this vessel. The drawback was that, once upon the Oregon shore, the road to Portland was very poor. In April 1888, it took close to an hour and one-half to travel one-way between the two cities via stage and ferry. ${ }^{19}$ In spite of this lengthy trip, the Oregonian asserted that "Records of the Vancouver Ferry show that nearly 50,000 people annually travel across the peninsula in stages and private conveyances." 20

In the early 1880s the Multnomah Railway Company was formed to build a street railway line between Portland and Albina (separate cities at that time) and thence north to the Columbia River opposite Vancouver. 21 The advantage of a railway is that with iron wheels on a smooth iron rail, the passengers would not be jostled around but would have a smooth comfortable ride. ${ }^{22}$ The reduction of friction resulting from iron wheels on iron rails meant that less power was needed to pull a given load when compared with pulling a wagon on a muddy road. The company managed to acquire several franchises, but this was its sole accomplish- 
ment. 23

In April 1888, with a view towards making some money from the steadily increasing travel between the two cities, and to make the district on the east side of the Willamette just north of the city of Albina more accessible (and therefore much more valuable), a group of Portland men began to apply for street railway franchises. They wanted to run a street railway from the Stark Street ferry north through East Portland and Albina to the Woodlawn district, which they were developing, and then on to the Vancouver ferry. ${ }^{24}$ On April 27, 1888, three members of the Oregon Land and Investment Company, Frank Dekum and R.I. Durham (both Portland bankers) and John B. David, incorporated the Portland and Vancouver Railway Company. ${ }^{25}$ In June they purchased all of the holdings of the Multnomah Railway Company, including the franchise for the Vancouver ferry for $\$ 25,000.26$

Portland had had a street railway system beginning with a horsecar line which began operation in late $1872 .^{27}$ Horsecar lines, though faster than travelling by horse and buggy on the muddy roads, were slow and typically limited to distances shorter than the eight miles between Vancouver and Portland. Both Portland and Seattle were building cable lines at this time, but this construction required a high degree of capitalization and was limited to areas where there were steep hills, such as the west side of Portland. ${ }^{28}$ At the time the Portland and Vancouver Railway Company was planning its line electrically powered street railway systems were just being perfected. In 1886 an electric street railway had been established in Montgomery, Alabama, and two years later a much more refined and reliable system was built in Richmond, Virginia. 29 
But it would be another year before the new technolgy would come to the Pacific Northwest. Seattle's first electric street railway ran in March 1889,30 followed by one in Portland in November. ${ }^{31}$ After examining the different options available for motive power, the decision was made to power the Portland and Vancouver line by steam.

There were certain disadvantages to using steam to power the street railways. In spite of attempts to muffle the heavy engines or "dummies" as they were called, they still were noisy and dirty. Two pieces of rolling stock were required (an engine and a passenger car) while the electrically powered street cars then being developed were self-contained units. But since it was easy to install and indeed could be used in building the lines, many communities began with steam and changed to electricity as their business grew and the technology improved. 32

Construction began on the Portland and Vancouver line in the summer of 1888 after engineer R.A. Habersham had surveyed the route and the necessary rights of way were secured. By August 150 men were at work laying the three-foot wide track, erecting over 8,000 feet of trestles across the Columbia River bottoms, and building a new ferry slip which would allow the passengers to pass from the cars to the ferry without exposure to the weather. The Phoenix Iron Works had orders to build two motors (dummies), and the cars were being built by John Hammond and Company, both firms located in San Francisco. The steel rails were purchased in Belleville, Illinois. Excluding the purchase of the ferry, the total cost for the construction and equipment of the eight miles of line was reported to be $\$ 160,000.33$ By the first week of October the 
line was in operation. 34

Despite some problems with the cars and motors' inability to negotiate the tight curves easily, it appears that the Portland and Vancouver Railroad enjoyed immediate success. 35 From October 5 th through the 31 st, 8847 passengers were carried between the two cities. This was two and one-half times as many as were travelling prior to the establishment of the steam line. ${ }^{36}$ The line was running eight round trips per day (increased to sixteen within one year), and the fare for the twenty minute one-way trip was twenty-five cents. 37

The objective of the Oregon Land and Investment Company to make its land more accessible, and therefore more salable, was apparently reached also. In early September the Oregonian reported that "New houses are springing up all along the line...." 38 , and the Independent asserted that in the month of December over twenty new houses had been commenced on the line of the railway between East Portland and Vancouver. 39

Of course this phenomenal success did not go unnoticed by the citizens of Vancouver. They, too, shared in this prosperity. The thousands of Sunday visitors coming over to view the garrison and the parade of troops lingered to adnire the town. Their interest materially benefited the city. The Independent disclosed that "The importance of our near proximity to Portland is shown by the heavy real estate purchases by gentlemen of that city." 40

The prominent men of Vancouver had seen what a railway bringing increased numbers of people to the river bank opposite the town had done for their town. They had also noted how the easy access to the Oregon 
Land and Investment Company's property, Woodlawn, which the railway had provided had increased the land's value and aided in its sale. Vancouver had been prosperous the past few years, thanks to the Vancouver, Klickitat and Yakima Railroad, the increasing population, the demand for lumber, and the fact that Washington Territory was apparently approaching statehood. With increasing frequency the question was being asked, "Was it time to build a railway on Vancouver's side of the river?" 
NOTES FOR GHAPTER I

1 Hubert Howe Bancroft, History of Washington, Idaho and Montana, 1845-1889, (San Francisco: The History Co., 1890), p. 389.

${ }^{2}$ Mary W. Avery, History and Government of the State of Washington, (Seattle: University of Washington Press, 1962), p. 188.

3 Dorothy 0. Johansen and Charles Gates, Empire of the Columbia, 2d ed., (New York: Harper and Row, 1967), p. 316.

4 Thomas R. Cox, Mills and Markets, A History of the Pacific Coast Lumber Industry to 1900, (Seattle: University of Washington Press, 1974), pp. 201-206.

5 Johansen and Gates, Empire of the Columbia, p. 335.

6 Avery, History and Government of the State of Washington, p. 188.

7 Johansen and Gates, Empire of the Columbia, pp. 338-340.

$8_{\text {Ibid., p. } 607 .}$

9 Estella D. Brown, "Some Activities of the Corps of Engineers in Oregon, 1866-1890," Reed College Bulletin 31, no. 5 (August 1953), p. 25 .

${ }^{10}$ James Neville Tattersall, "The Economic Development of the Pacific Northwest to 1920," (unpublished Ph.D. thesis, University of Washington, Seattle, 1960), p. 78 .

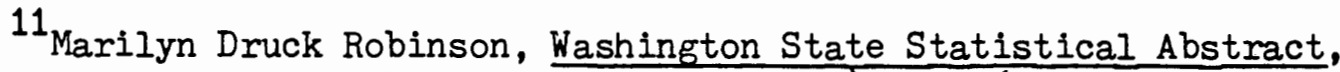
(Seattle: University of Washington Press, 1952), p. 16.

12 Victoria L. Ransom, "Officers' Row at Vancouver Barracks," Clark County History Annual 3 (1962), p. 41.

13 Bruce Cheever, The Development of Railroads in the State of Washington, 1860-1948, 2 vols. (Bellingham: Western Washington College of Education, 1949), p. 106. 
${ }^{14}$ Clarke County Register, 22 September 1887.

15 Roy F. Jones, "The Name Was Hidden," Clark County History Annual $?(1966)$, p. 167 .

${ }^{16}$ Cox, Mills and Markets, p. 209.

${ }^{17}$ Clarke County Register, 10 May 1888.

${ }^{18}$ Cheever, The Development of Railroads in the State of Washington, 1860-1948, p. 106.

${ }^{19}$ See Vancouver Independent, 11 April 1888 (hereafter cited as Independent); and Portland Evening Telegram, 14 February 1917.

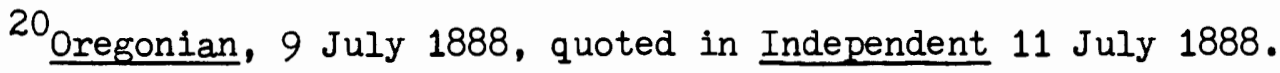

${ }^{21}$ John T. Labbe, Fares, Please! Those Portland Trolley Years, (Caldwell, Idaho: Caxton Printers, 1980), p. 33.

22 John Anderson Miller, Fares, Please! A Popular History of Trolleys, Horse-cars, Street Cars, Buses, Elevateds, and Subways, (New York: D. Appleton-Century, 1941), p. 22 .

23 Labbe, Fares, Please!, p. 33.

24 Ibid., pp. $44-45$.

${ }^{25}$ See Ibid.; and E. Kimbark MacColl, The Shaping of a City: Business and Politics in Portland, Oregon, 1885-1915, (Portland: The Georgian Press Co., 1976), p. 139.

${ }^{26}$ Independent, 13 June 1888.

27 Labbe, Fares, Please!, p. 45.

28 See Ibid., p. 56; and Daniel E. Turbeville, III, The Electric Railway Era in Northwest Washington, 1890-1930, Occasional Paper no. 12., (Bellingham: Center for Pacific Northwest Studies, Western Washington University, 1979), p. 20.

${ }^{29}$ Miller, Fares, Please!, pp. 56-57, 62-68. 
30 Turbeville, The Electric Railway Era in Northwest Washington, 1890-1930, p. 20 .

${ }^{31}$ Labbe, Fares, Please!, p. 67.

32 Ibid., p. 37 .

33 Independent, $30 \mathrm{May} ; 11 \mathrm{July;} 8$ August; and 13 June 1888.

${ }^{34}$ Labbe, Fares, Please!, p. 46

35 Ibid.

36 Independent, 17 November 1888.

${ }^{37}$ Labbe, Fares, Please!, p. 47.

${ }^{38}$ Oregonian, quoted in Independent, 5 September 1888.

39 Independent, 2 January 1889.

${ }^{40}$ Ibid., 27 January 1889. 
THE COLUMBIA IAND AND IMPROVEMENT COMPANY, 1888-1892

In late 1888, a group of Vancouver businessmen incorporated the Columbia Land and Improvement Company with a reported capital stock of $\$ 100,000 .^{1}$ The incorporators, S.W. Brown, L.M. Hidden, P.C. McFarlane, W.S. Patten and Louis Sohns, were all prominent in the city and were involved in such enterprises as journalism, brick manufacturing, cooperage, banking and the water company. ${ }^{2}$ Several of them held positions in local politics. Louis Sohns, a prominent merchant, for example, had been a member of the territorial legislature and the mayor of Vancouver, and was on the board of trustees for the School for Defective Youth. ${ }^{3}$ S.W. Brown had been mayor and receiver of the iand office. 4

These men secured over 500 acres of land north of the city near Burnt Bridge Creek and east around the military reservation to the vicinity of the School for Defective Youth. 5 The property was bisected diagonally from southwest to northeast by the Vancouver, Klickitat and Yakima Railroad track and was about one and one-half miles up Main Street from the ferry landing on the Columbia River. Since the tract was 200 feet higher than the river, it was named Vancouver Heights.

The intent of the development company was to lay out its property in lots for homes, to build a water system for it, and to "buy, lease, build, construct, maintain and operate railroads and street railroads, also to build, construct and maintain in repair, streets and roads ad- 
jacent to, or leading to or from its property."6 The incorporators realized that the more accessible their property was (which a street railway would facilitate), the more valuable it would be and therefore more easily sold. On the 7 th of January, 1889, they applied to the city council for a franchise for a street railway. ${ }^{7}$ The Vancouver Independent said that "Everyone knows that such a railway will not pay in Vancouver now, but it will if the promises of growth are fulfilled, and the railway itself will be an important factor in stimulating such growth."8 Four weeks after the company had petitioned the city council for the franchise, it was approved. There had not been much opposition to it; perhaps the fact that the mayor, Charles Brown, was the son of one of the incorporators may have aided its passage. The merchants along lower Main Street were a bit concerned when they found out that the franchise allowed the company to build a double track, which they were afraid would take up too much of the narrow lower Main Street. However it was pointed out to them that the tracks imposed only "very slight obstructions" and that it was "better to allow this that to force the building of the line on another street to which all new business will go...." and the merchants' misgivings were dissipated. ${ }^{9}$

The franchise granted by the city was to mun for fifty years and dictated the responsibilities the company must meet for the privilege of running the railway on the city's streets. First, it clearly defined the route that the railway was to take. It was to commence at First and B Street (by the ferry dock), then west one block to Main, and north on Main to Vancouver Heights. Three spur lines were to be built running east from Main Street to the military reservation on Fifth, Tenth and 
Eighteenth streets, and a fourth spur line was to run west on Eleventh to the western boundary of the city. A minimum amount of track was to be laid by July 1, 1889 (from B Street and First up Main and the Tenth Street spur), and if the entire line was not completed within two years of that date, the franchise would revert to the city of Vancouver. ${ }^{10}$

The fares charged and the frequency of the running of the street cars were also regulated by the franchise. The maximum charge that could be made for carrying one passenger from any point on the line to the terminus could not exceed five cents, and the cars were required to run at least every two hours during the day between the hours of 7:00 AM and 6:00 PM. ${ }^{11}$

As the opposition that arose concerning the use of double tracks on lower Main Street indicated, there was some concern about what the tracks would do to the streets. The citizens were afraid that water might collect and run down the natural paths formed by the rails, leading to gulleys in the street which would make crossing them with wagons very difficult. The franchise stated that the track (whether single of double) should:

be laid as nearly as practicable in the center of the Streets and ... shall keep in repair, equally good with the remainder of the street that portion of the street or streets along and over which the railway track shall be laid, the whole width of said railway between the tracks and for the width of one foot on the outside of said rails, except across bridges where only the covering plank shall be kept in repair. 12

If the people of Vancouver wanted a street railway, as apparently they did, they did not want it at the expense of their streets.

Concerning the motive power of the railway, the franchise eliminated steam as a possibility but said that the cars could "be drawn by 
horses or mules or to be propelled by electricity or cable." ${ }^{13}$ Both horse car lines and cable car systems were present in the Pacific Northwest. Portland had had the former since 1872 and began installing its first cable line in 1887 (it commenced operation in February 1890) to develop the heights west of the city. ${ }^{14}$ Seattle had begun construction on a cable line in 1887.15

The chief advantage of the cable systems was their power. Horse drawn lines had difficulty pulling cars uo the hills, and since both Portland and Seattle had some fairly steep hills, the cable car systems were well suited to them. One benefit to building a horse drawn line was the much lower capitalization required. To build a cable system, a large power plant was needed to move the miles of cable which were placed underground at great expense. The cars for a cable system were more expensive because of the "grip" mechanism needed. Since there were no steep hills in Vancouver where the new line was to run and there was not likely to be the business to justify the capitalization which a cable system or electrically powered line would demand, the Columbia Land and Improvement Company wisely chose to power its railway with horses. The franchise did provide for several possible systems so they could change to a different one as business required or technology improved.

Having received the franchise and made their decisions concerning the construction of the railway, the company began building in earnest. Within two weeks they had telegraphed Chicago for $\$ 4,000$ worth of iron rails and had begun clearing streets in the Vancouver Heights addition. ${ }^{16}$ Timber and ties were ordered from the city's mills and by February 27 th, the property was platted and staked out. 17 
Vancouver's business was booming. - Not only had they begun a street railway, but the city's first electric lights were lit on February 5th, and the prospect of statehood appeared very likely with the passage of the Omnibus Admission Bill later that month. ${ }^{18}$ Large crowds continued to come over from Portland and "travel was increasing daily"19 on the Portland and Vancouver Railway with nearly 2,000 people visiting Vancouver one March Sunday to view a parade at the military reservation. 20 The Independent reported that the "rush at the Vancouver Land Office remains unabated.... the officers [are] having all they can do to attend to the applicants." 21 There were no houses available to rent. 22 Actual construction of the street railway was delayed in starting for a few weeks because of a mix-up in shipping the rails. They were delivered to Kalama instead of Vancouver, and the freight bill was nearly doubled over the company's expectations. It took about ten days to get straightened out, and the rails were delivered to the Government Dock in Vancouver in the middle of April. 23

Ground was broken on the 23rd of April, and construction proceeded rapidly. In five weeks the twenty men at work had completed the track up to the garrison gate on Tenth Street. It had been decided that a single track would be best to begin with, and a second one could be laid "within the year" as business demanded. 24 Four hundred and thirty dollars were spent to purchase four horses, 25 and two cars were ordered from the Pullman Car Company of Illinois for $\$ 1900.26$ The cars arrived on the 14 th of June and were put right on the line. 27 The Independent proclaimed proudly, "The Vancouver Street car line is in operation and now we are up to the times with every city on the coast."28 


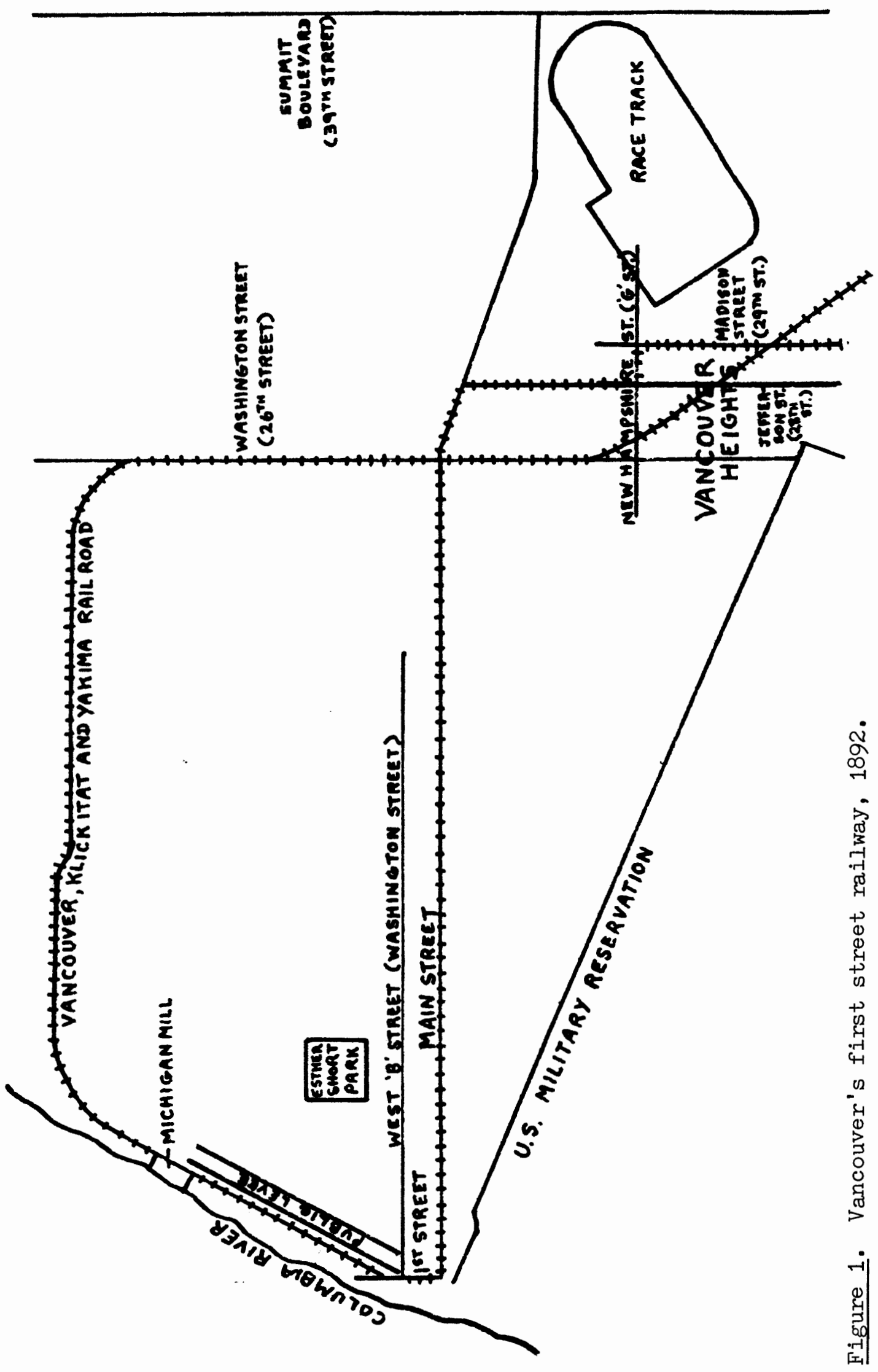




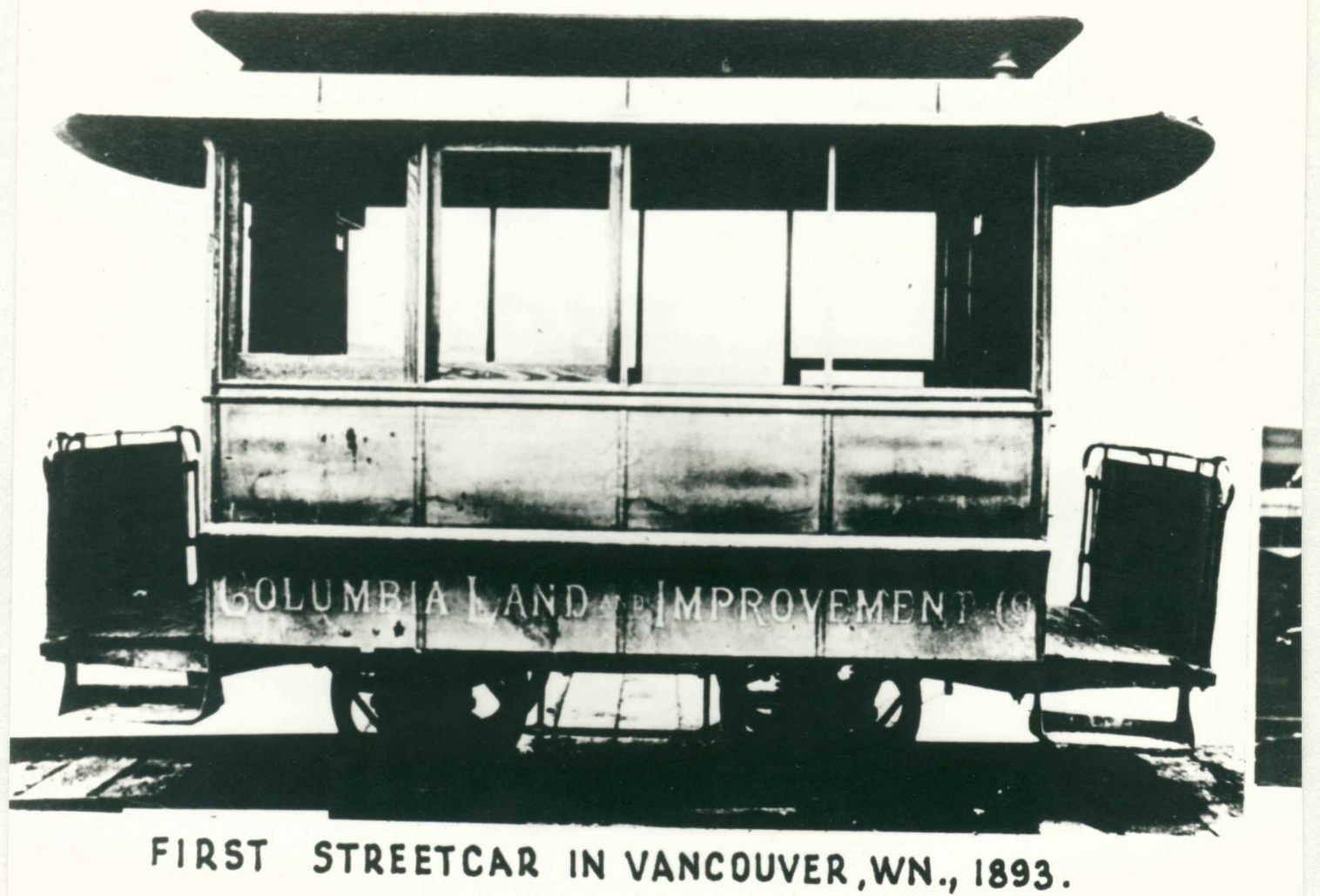

Figure 2. Columbia Land and Improvement Company Street Car. The date in this photograph is incorrect since the system was electrified in 1892 and this is a horse drawn car, (Oregon Historical Society Photograph Collection.)

It appears that the street car line was received with great enthusiasm initially. Everyone wanted to ride it. During the first month of operation over 5,000 passenger rides were given. ${ }^{29}$ This included the Fourth of July celebration which attracted a crowd of people from Portland, over 12,000 according to the optimistic Independent, and it is likely that many of these visitors rode the new line. 30 By the end of December, after six and one-half months of operation, the Columbia Land 
and Improvement Company had taken in over $\$ 1,000$ in fares, which at five cents a ride comes out to about 3,000 rides per month. 31

How profitable was the street railway, in itself, to the Columbia Land and Improvement Company? It is difficult to assess this precisely because the surviving company records for the first months do not indicate exactly what the expenses and revnues were over a given amount of time. For example, the entries for fares collected during the first three months show figures for deposits on June 29th, July 22nd and August 2 nd and $16 \mathrm{th} .32$ This lack of a regular period between deposits makes it difficult to discern whether the number of passengers was increasing of decreasing from month to month. There is the same problem with operating expenses. But in spite of the inexactedness, it can be demonstrated that the street car system, in itself, was not profitable from the very beginning.

Prior to receiving any income from the railway, the company had invested quite a bit in the construction and equipping of it. The iron rails, Pullman cars, and horses cost about $\$ 6,500$. Other expenses were for ties and lumber for the stable and barn, and for labor, all of which totaled just under $\$ 12,000$ in construction costs. 33

Operating expenses for the first year were entered the same way as the fares were, that is, not on a regular basis. It appears that the company was spending about $\$ 70$ per month for stabling and feeding the horses and about $\$ 135$ per month on labor. Of course there were occasional other miscellaneous expenses such as horseshoeing $(\$ 21.50)$ and track cleaning (\$11). In March a new wheel was required for one of the cars at a cost of $\$ 72.70 .34$ 
Comparing the rough average of operating expenses, just over $\$ 200$ per month for the first year, with the income from the fares, $\$ 137$ per month for the first year, it can be seen that the company was losing money on its street railway at the rate of about $\$ 60$ per month just in consideration of operating expenses over income. For the street railway to have been profitable, it would have had to be earning enough to pay off the cost of construction $(\$ 12,000)$ as well as to maintain and purchase new equipment. For example, depending on how they were treated, horses used on the railway would last for only a few years and one employed in this way was generally worn out and not worth much for resale. The wheel replaced in March 1890, was an expense half as large as the company's average monthly fare revenues.

Anothe measure of the street railway's "profitability" is its effect upon real estate sales. The Columbia Land and Improvement Company had built it to make its property, the Vancouver Heights, more accessible and therefore more salable. The Independent reported in July 1889, that "more new houses are being built in Vancouver this season than ever before in any one year" and that the "banks are doing double the business of six months ago."35 In February 1889, the West Shore carried a large advertisement for the new addition stating that the real estate company handling the sales had a wagon ready for anyone who wished to inspect the lots. ${ }^{36}$ When the street railway began running in June, thousands of people viewed the area. ${ }^{37}$ Despite all of this exposure to potential customers and the general prosperity that Vancouver was enjoying, only five sales were made by the end of December 1889, for a total of $\$ 4,200$ (one sale in July for $\$ 1,000$; two in August for $\$ 2,000$ and 
$\$ 400$; and one each in September and December for $\$ 400$ each). 38 The first half-year of the street railway's operation did not portend any great future financial success.

In early 1890 Vancouver's economy accelerated. The achievement of statehood the previous November was probably a factor, but the major boost was the renewed railroad construction. General Manager C.J. Smith of the new Pacific Division of the Union Pacific Railroad "admitted that his company had under consideration the building of a line to Puget Sound from Portland, Oregon"39 in December 1889. His company conferred with Vancouver businessmen in April about bridging the Columbia there 40 and purchased a survey done by the Portland and Puget Sound Railroad Company which had been incorporated in 1889 to build a line from Port Townsend to Portland. 41 Commencing in August to construct the line, the Union Pacific within five weeks had 2,000 men in fifteen camps between Vancouver and Kalama at work, with more further north. 42 The West Shore said, in reference to Vancouver finally getting a transcontinental connection, that the city was "having a very flattering growth." 43

After an unusually cold January which saw the Columbia River frozen over and the street railway idled by snow for most of the month, during February a number of lots were sold in the Vancouver Heights. 44 This prosperity was sustained through July with twenty-five sales in this six month period for a total of $\$ 19,670.45$ The Independent loudly proclaimed this brisk upturn in real estate sales and, to give evidence of its boosterism, began to publish a list of real estate transactions which had taken place the previous week. 46

In light of the imminent arrival of the city's first transconti- 
nental railroad and the apparent success of the street railway line (successful at least in selling real estate), it is not surprising that another plan for a street railroad was brought forth. On July 7, 1890, George Hitchcock, a realtor, C.L. Gray, and several associates, appeared before the city council to apply for a franchise to build a street railway. The line that the Pacific Street Railway and Real Estate Company planned to construct would run between the established one and the military reservation north to Thirteenth, and then west several blocks to the site where the Union Pacific depot was to be constructed. It would be able to meet the passengers as they came off the ferry, take them the three blocks to the Hotel Columbia (which was then under construction) or on to the depot. And it was to be an electric powered line. ${ }^{47}$

The city council passed the ordinance granting the franchise on August 4 th. It was very similar to the one given to the Columbia Land and Improvement Company with a few notable exceptions. This franchise gave them six months to commence construction and then nine more to complete it. They were allowed to power it in any of the ways that the first franchise had granted, but were also given permission to erect poles and wires along the city streets. Street maintenance obligations, fares, schedules and length of franchise were the same, too. But evidently the city council believed that the city was going to grow a lot with the coming of the Union Pacific and they were not about to give this franchise away. Accordingly they made provisions that the holders of the franchise were to pay the city each December, after construction was completed, $\$ 25$ for each one-horse car, $\$ 50$ for each two-horse car, and $\$ 75$ for each car propelled by electricity used during that year on 
their railway. 48

Prior to beginning any construction of their railway, the planners officially incorporated under the name of the Vancouver Street Railway Company. The incorporators were C.L. Gray, P.C. McFarlane, George Hitchcock, Ed F. Hitchcock, W. Byron Daniels, P.C. Kauffman and S.M. Beard, all prominent businessmen. It was hinted that they had other lines in contemplation, too. 49

Vancouver's prospects for future growth had never looked brighter than in the fall of 1890 . It had one street railway in operation with a modern electric one in preparation and real estate was selling reasonably well. One pier of the new railroad bridge across the Columbia River was nearly completed, and construction was proceeding on the rest of the line. However, the Union Pacific was experiencing serious financial difficulties as a result of heavy bond indebtedness and unwarranted expansion of its branches. Cutting expenses was a necessity. 50 On December 15 th the executive committee of the company in New York sent word that they were to suspend work on the line, close contracts and pay off the employees. 51 The Independent bravely proclaimed through the next few months that they believed it to be a temporary shut-down but the work was never resumed by the Union Pacific. 52 It would be a decade before Vancouver got a transcontinental connection and almost two before the river was finally bridged.

With the deferment of the railroad construction looking likely, Vancouver's boom bottomed. Even the ever-optimistic Independent revealed in February that "the change of business since work ceased has been too apparent to need comment...."53 The Vancouver Street Railway Compa- 
ny began some construction in February, but as it became increasingly obvious that the Union Pacific was not going to complete its line, work soon ceased on what would have been Vancouver's first electric line. ${ }^{54}$

The decline of Vancouver's economy, precipitated by the withdrawal of the Union Pacific, was shared by the street railway. From June 1890 through March 1892 operating expenses averaged $\$ 248$ per month while fare revenues averaged $\$ 119$ per month, and both figures dropped steadily (see figure 3). During the last six months of this period expenses were $\$ 159$ and fares $\$ 54$ per month. 55

In spite of the Union Pacific's departure and the city's subsequent recession, William L. Browne of Nebraska expressed interest in buying the street railway system. He had begun a law practice in Plattsmouth, Nebraska, and had also been engaged in railroading there. 56 In a letter published in the Independent, June 3, 1891, he offered to purchase the city-owned electric plant, the street railway (which he would electrify) and establish an electric lighting and manufacturing plant. A public meeting was held at which the people voted "overwhelmingly" to sell the plant to him, and an ordinance was quickly prepared and passed by the city council granting him a franchise to erect poles, furnish lights and purchase the plant. In early July, Browne accepted the provisions of the franchise, including one that he was to develop in the city a manufacturing industry that would employ twenty or more persons to produce incandescent lamps and various other kinds of electrical equipment. 57 Two weeks later he reappeared before the council asking for another thirty days to complete the purchase and this was granted. The Independent predicted pessimistically that "to a man up a tree it 


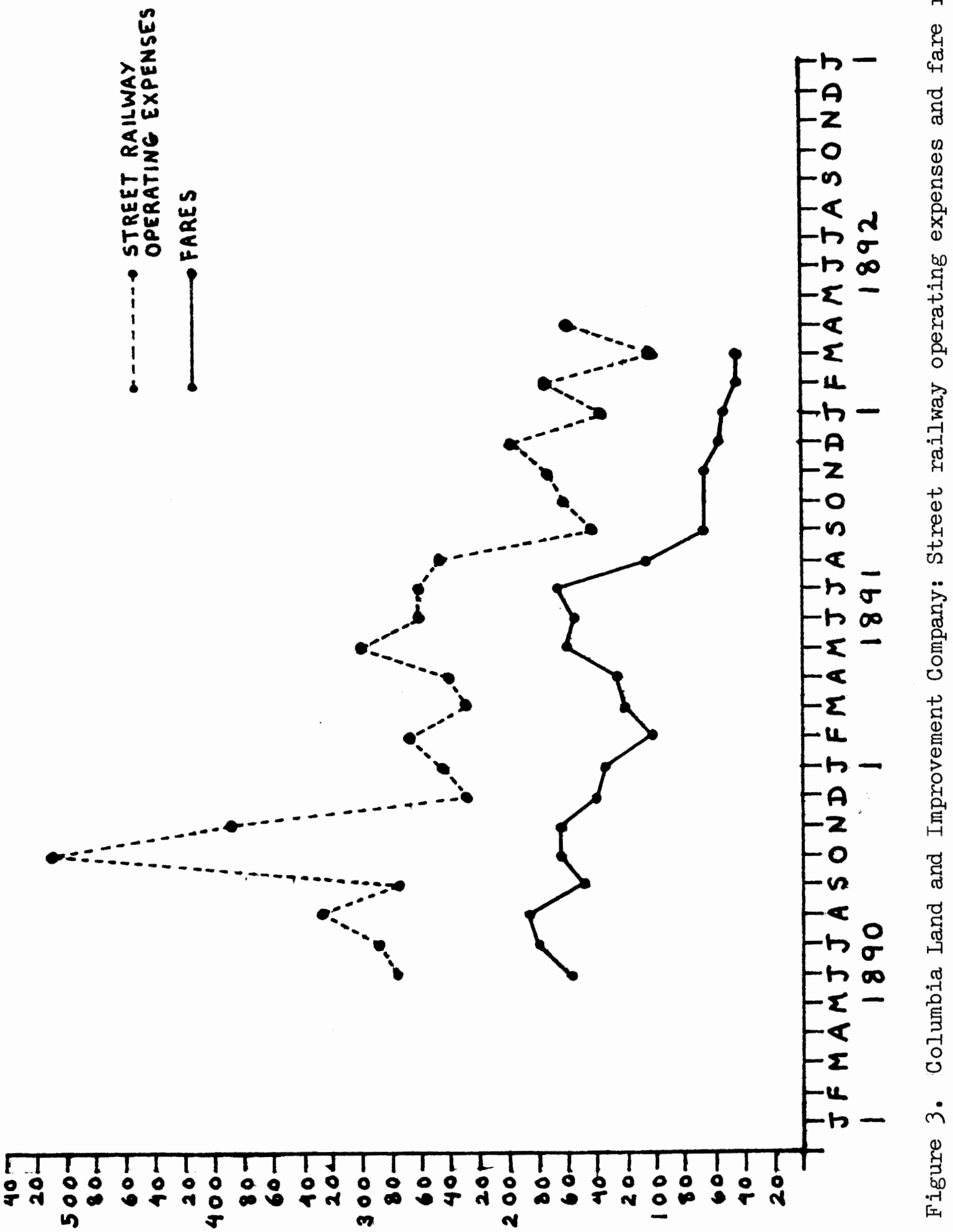


begins to look as though $\mathrm{Mr}$. Browne will fail to materialize...." 58 A month later with no action from him the council repealed the franchise. 59

Street railways during this period were finding that their peak ridership occurred during the day, Monday through Friday, with few passengers in the evenings or on Sundays. Since most of them were required by their franchises to run cars in the evening and on Sundays, these were profitless times of operation for them. In order to make them profitable, some scheme had to be devised to lure people out at these times. Consequently, a number of street car systems developed amusement parks or similar attractions. The terminus of the line was usually chosen because it was the least profitable part of the line and land was likely to be cheapest there too. 60

To increase riderships on their railway during the sparse periods of operation and bring more people to its property in the Vancouver Heights, the Columbia Land and Improvement Company aided in the development of Vancouver's first race track in 1892. On March 20th it sold sixty acres of land located immediately north of Vancouver Heights to the Vancouver Driving Park Association. 61 The incorporators of the association included some of the same people who were involved in the CoIumbia Land and Improvement Company, such as P.C. McFarlane. 62

Construction soon commenced and the track was completed by June. The first races had been announced far enough ahead of time so that horse owners could include Vancouver in their circuit with Portland and Salem. They were to be held on August 30th and 31st and September 1st and 2nd. 63 
Meanwhile the financial condition of the street railway company steadily deteriorated. In the summer of 1891 it had to recondition part of its track on lower Main Street in conjunction with the paving of the street by the city. Although it managed to get the city council to allow them to plank between the rails instead of paving as the franchise had required (a situation which led to council member and part-owner of the street railway, L.M. Hidden, being accused by Mayor J. Randolph Smith of a "conflict of interest"), it was still quite expensive. 64 In June the company mortgaged its property for $\$ 25,000$ with a Portland firm, the Columbia Fire and Marine Insurance Company. 65

Fare revenues continued to drop. From October 1891, through March 1892, fares averaged $\$ 54$ per month. The last two months averaged $\$ 45$ each. 66

The reasons for the decline in ridership are not clearly indicated, but the newspapers hint at some of the causes. In June the line passed its second anniversary and the cars were likely looking the worse for wear after two years of use. The company's ledger does not cite any expenditures to renew them. The Independent in September 1891, queried, "What has become of the C.L. \& I. Co.'s garrison car? It has not been in sight for two weeks." 6 ? In mid-August one car got off the track demonstrating that some repairs were needed, but apparently the only ones done were those that were required by the franchise to maintain the streets. 68

The novelty of riding in a horse drawn street car had probably worm off also. Vancouver had had two chances for an electric railway, one of which would have been an entirely new line, but both possibili- 
ties had fallen through. Portland had had an electric line since November of 1889, and they were known to be more modern, cleaner and quicker than the smelly, plodding, horse drawn systems.

The downturn in Vancouver's economy after the withdrawal of the Union Pacific had an effect on the ridership of the street railway. Since there was less interest in purchasing real estate, fewer people rode out to view the lots on Vancouver Heights.

For the street railway to survive and become profitable, the number of passengers would have to increase; for this to happen new reasons to ride it were needed. The race track would help draw business to the line, but far better would be another real estate "boom." An infusion of capital to repair the track and electrify the system into a modem line that the citizens of Vancouver would be proud to ride on would also raise the ridership. If the Columbia Land and Improvement Company could not provide the money, then perhaps an outside investor would be willing to speculate on Vancouver's first street railway. 
${ }^{1}$ Independent, 9 January 1889.

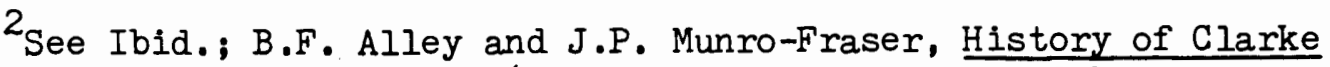
County, Washington Territory, (Portland: The Washington Publishing Co., 1885), pp. 347, 363 and 378; and Milton Bona, "Louis Sohns Came to County with Grant," Clark County History Annual 16 (1976), pp. 46-48.

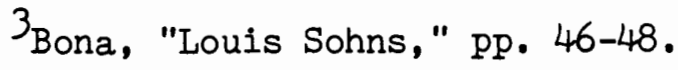

${ }^{4}$ Alley and Munro-Fraser, History of Clarke County, pp. 347,363 and 378 .

5independent, 9 January 1889.

${ }^{6}$ Ibid.

7 Vancouver City Council, Minutes, 7 January 1889. (herafter cited as Vancouver, Minutes).

8 Independent, 16 January 1889.

${ }^{9}$ Ibid., 6 February and 16 January 1889.

${ }^{10}$ Vancouver City Council, Ordinance Number 200, (5 February 1889).

${ }^{11}$ Ibid.

12 Ibid.

${ }^{13}$ Ibid.

${ }^{14}$ Labbe, Fares, Please!

15 Turbeville, The Electric Railway Era in Northwest Washington, 1890-1930, p. 20. 
${ }^{16}$ See Columbia Land and Improvement Company, Ledger Number One, 1889-1899, Puget Power Collection, Center for Pacific Northwest Studies, Western Washington University, p. 36 (herafter cited as CLIC, Ledger.); and Independent, 20 February 1889.

${ }^{17}$ Independent, 27 February 1889.

${ }^{18}$ Ibid., 13 February 1889.

${ }^{19}$ Ibid., 27 March 1889.

${ }^{20}$ Ibid. , 13 March 1889.

${ }^{21}$ Ibid., 20 February 1889.

22 Ibid., 27 February 1889.

${ }^{23}$ Ibid., 3 and 17 April 1889.

${ }^{24}$ Ibid., 24 April and 29 May 1889.

${ }^{25}$ CLIC, Ledger, p. 36.

${ }^{26}$ See Ibid., p. 43; and Labbe, Fares, Please!, p. 78.

${ }^{27}$ Labbe, Fares, Please!, p. 78.

${ }^{28}$ Independent, 19 June 1889.

${ }^{29}$ CLIC, Ledger, p. 36.

${ }^{30}$ Independent, $10 \mathrm{July} 1889$.

${ }^{31}$ CLIC, Ledger, p. 36.

32 Ibid.

33 Ibid., p. 43.

${ }^{34}$ Ibid., p. 47.

${ }^{35}$ Independent, 17 and $24 \mathrm{July} 1889$. 
36 West Shore, February 1889.

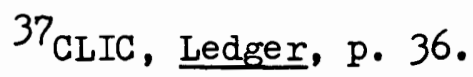

${ }^{38}$ Clarke County Auditor, Deeds and Mortgages, Book 4, pp. 515 , 552, 580 and 637; and Book 5, p. 394.

39 Frank B. Gill, An Unfinished History of Transportation in Oregon and Washington, $(1914-1920)$, p. 224 .

${ }^{40}$ Independent, 30 April 1890.

${ }^{41}$ Cheever, The Development of Railroads in the State of Washington, 1860-1948, p. 122 .

42 Independent, 13 August and 24 September 1890.

43 West Shore, quoted in Independent, 1 March 1890.

${ }^{44}$ Clarke County Auditor, Deeds and Mortgages, Book 5.

${ }^{45}$ Ibid., Books 5,7 and 9.

${ }^{46}$ Independent, 5 March and 9 April 1890.

47 Ibid., 9 July 1890.

${ }^{48}$ Ibid., 6 and 20 August 1890.

${ }^{49}$ Ibid., 19 November 1890.

50 Robert G. Athearn, Union Pacific Country, (New York: Rand McNally and Co., 1971), p. 355 .

51 Vancouver Register, 17 December 1890.

52 Independent, December 1890 - April 1891 passim.

53 Ibid., 11 February 1891.

${ }^{54}$ Labbe, Fares, Please!, p. 78. 
${ }^{55}$ CLIC, Ledger, p. 48.

${ }^{56}$ Letter of Andrea I. Paul, Nebraska State Historical Society, to author, 19 July 1983.

57 Independent, 3 and 24 June; and 8 July 1891.

58 Ibid., 22 July 1891.

59 Ibid., 26 August 1891.

${ }^{60}$ Randall V. Mills, "Early Electric Interurbans in Oregon. 1. Forming the Portland Railway, Light and Power System," Oregon Historical Quarterly 44 (March 1943), pp. 94-95.

${ }^{61_{\text {See }}}$ Dorothy Carlson, "Vancouver's First Race Track," Clark County History Annual 15 (1974), p. 383; and Clarke County Auditor, Deeds and Mortgages, Book 15, p. 100.

62 Carlson, "Vancouver's First Race Track," p. 384.

63 Ibid.

64 Vancouver, Minutes, 30 March; 20 and 27 April; and 12 May 1891.

${ }^{65}$ Clarke County Auditor, Deeds and Mortgages, Book 10, p. 80.

${ }^{66} \mathrm{CLIC}$, Ledger, p. 36.

${ }^{67}$ Independent, 2 September 1891.

${ }^{68}$ Ibid., 19 August 1891. 
CHAPTER III

CONSOLIDATION AND DECLINE, 1892-1897

As street railways improved transportation between communities, they also aided in the development of closer ties between them. Around Albina and East Portland the population filled in and there was growing interest in consolidation. Merging in the summer of 1891 with Portland, they formed one large city under the latter's name. There were a number of street railway systems, horse drawn, steam and electric in Portland, and there was pressure from the citizens for improved service. To try to meet these demands a group of Portland businessmen and bankers, James Steel, R.L. Durham, D.F. Sherman, W. McNeill all led by the energetic George B. Markle, began to formulate plans to consolidate some of the lines. Its goal was to unite the Multnomah Street Railway Company, the Metropolitan Railway Company, the Portland Traction Company, the Portland and Vancouver motor line, and the Vancouver horse drawn line, into one single operating company. This would make it possible to ride from the Riverview Cemetery north to Vancouver Heights all on one line. ${ }^{1}$

George B. Markle, a descendent of a wealthy Pennsylvania family, was prominent in Portland's business community. Young and industrious, he was involved in the organizing of a number of enterprises including the Portland Hotel, the Oregon National Bank, the Northwest Loan and Trust, Portland Mining and Sunset Mines, the Ellensburg National Bank, the Commercial Bank of Vancouver, the North Pacific Industrial Associa- 
tion, Portland Tanning, and the Columbia Fire and Marine Insurance Company. ${ }^{2}$ Markle was no stranger to the streets of Vancouver. In late 1887 he had purchased five parcels of real estate there and two more in each of the next two years. ${ }^{3}$ A street in West Vancouver was named Markle Avenue in his honor. He was important enough for the Independent to note his visits to the city in the spring of 1889, announcing, "Mr. Geo. B. Markle's fine team is often seen on the streets of Vancouver. "4 In June of 1889 occurred the "greatest social event of the season" when he married Kate Goodwin, daughter of Lieutenant and Mrs. Wm. P. Goodwin, at the Vancouver Barracks. 5 The Markles made their home in a very fine house on the heights in West Portland, and we prominent in social activities. 6

In light of the unprofitability of its street railway and the dropping off of real estate sales, the Columbia Land and Improvement Company was likely eager to sell its line, particularly to someone such as the "millionaire banker," Markle, who intended to connect it with the Portland lines and electrify it. The Columbia Fire and Marine Insurance Company to which it had mortgaged their real estate in June 1891, was a firm in which Markle had an interest and it was required to pay $\$ 500$ quarterly to this firm, a burden which was probably becoming increasingly difficult to bear.?

On March 14, 1892, Markle signed an agreement with the Columbia Land and Improvement Company to purchase its railway for one dollar "and other good and valuable considerations" (which presumably concerned an easing, if not cancellation, of the mortgage demands). ${ }^{8}$ This sale was not recorded in the county auditor's office for six weeks, nor was it 
noted in the newspapers. There were some other matters to take care of before the sale was widely known.

April 4, 1892, at a city council meeting, the Columbia Land and Improvement Company applied for a franchise to expand its railway and "to erect poles and wire in and over the streets of the city of Vancouver" in order to electrify it. 9 Markle was present and requested haste in their consideration of it. 10 Several weeks later the city council discussed the franchise at great length with some members voicing objections to it because it permitted the company to build on streets that were not yet opened, and were indeed outside of the city Iimits. 11 Concerning Main Street it said, for example, "...along Main street to the northern boundary of the city, and along any northerly extension or continuation of Main street which may hereafter be made." There were similar provisions for Fifth, Tenth and Twelfth streets, and Markle Avenue. The Company also desired permission to construct its line along streets

... as it may be necessary to traverse, in order to construct and operate its system of railways by such routes as said Company or its assigns may desire, to and from any station, depot or depot grounds which may be established by the Union Pacific Railway Company or Portland and Puget Sound Railway Company, or other Railway Company running trains over the railroad bridge across the Columbia River. 12

The critics of this "Blanket Ordinance," as they called it, said the city did not have the right to grant a fifty-year franchise on all these potential streets. At this point in the meeting, Markle, who was attending with his attorney, O.F. Paxton, was invited to address the council and he "stated that he did not approve of the delays they were being subjected to as it lessened the time in which they were expected to work."13 He was referring to the fact that they desired to have the 
line electrified prior to the races to be run at the new race track at the end of August, four months hence.

Other concerns raised at the meeting included the style of rails to be used because the characteristics of the " $\mathrm{T}$ " rails commonly in use made paving between them difficult. It was suggested that the city attorney be instructed to examine the franchise further, which would have meant a longer delay, but councilman L.M. Hidden, who owned stock in the Columbia Land and Improvement Company, objected, stating that the ordinance had been deferred long enough and he did not see the necessity for further delay. Mayor W. Byron Daniels agreed, reminding the council of the importance of immediate action, and Markle repeated that it was an absolute necessity the he learn the fate of the franchise at this meeting. Councilman Brewster persevered in his opposition to the ordinance and it was referred to the city attorney to examine and report back at this same meeting. His report was favorable and the ordinance granting the franchise passed by a vote of four to two (with one councilman absent). ${ }^{14}$ On April 30th the Columbia Land and Improvement Company formally accepted the franchise from the city and recorded the sale of its street railway to George Markle with the county auditor. ${ }^{15}$ Vancouver was finally to enjoy a modern electric railway system as part of a thirty-five mile line supported by one of the wealthiest capitalists in the Pacific Northwest. The Independent called it a "long step forward toward metropolitanism." 16

One of the first considerations to be faced by the new owners as they planned the electrification of the system was where to locate the powerhouse. The company claimed that the "power station is required to 
be adjoining the Columbia River" (for reasons not totally clear) and accordingly applied to the city council for the right to use 220 feet of the public levee for fifty years, free of charge, since their electrification of the street railway would "greatly facilitate travel and subserve the public comfort and be of public benefit."17 The council amended the franchise, insisting that the company pay the costs of any necessary improvements of the portions of the levee they occupied, and then passed it. ${ }^{18}$ Markle's company duly accepted the franchise but never built a power house on that site. Instead it purchased several lots from the Michigan Lumber Company located on the river a couple of blocks west of the levee (eight blocks west of Main Street), and built a power house there. 19

Although construction on the railway track did not commence until July 12th, it then proceeded rapidly. Main Street was regraded where it intersected with Eighth to minimize the hill there, and by August 10th the poles along Main Street were in position. For the next two weeks the work continued at an even more rapid pace as the company strove to finish it by the first race. 20

As the electrification of the Vancouver line progressed, Markle and his associates took the final steps in consolidating the various lines that they had acquired. In May the Portland Consolidated Street Railway Company was incorporated, and at the end of July the negotiations for the uniting of the railways were formally consummated. Markle was president; James Steel, vice-president; D.W. Sherman, secretary; and J.L. Hartman was the treasurer. They had secured a $\$ 1,500,000$ mortgage from the Mercantile Trust Company of New York, and all the lines were 
brought under one management in early August 1892.21

The first car to run of the Vancouver electric line was brought over from Portland on the 26th of August. 22 It was an open car, manufactured by the J.G. Brill Company in Philadelphia, and had been used on the Multnomah Street Railway. ${ }^{23}$ The company's power house had not yet been completed so an arrangement was made to purchase electricity from the Michigan Lumber Mill's dynamo, and on the 27th the first run was made. Departing from the front of the Hotel Columbia, the car gingerly headed north on Main Street with forty-eight passengers, including the mayor, city council members, and representatives of the press. After a brief inspection of the new race track, the return trip was made in eight minutes, including several stops. Crowds along the way cheered the car as it went clattering past and presented the men in charge with bouquets of flowers. After its initial trip, the car made several more, carrying crowds of people free of charge. 24

August 30,1892 , the first race was held at the Vancouver Driving Park and many people came to view it. Even with a second car operating (which like the first had a capacity of ninety passengers), the Independent reported that "some difficulty was experienced in moving the $\mathrm{m}$ out to the track."25 It was worse in the afternoon, particularly when some of the equipment temporarily failed, just when the crowd was at its peak. Still transportation was improved; it was now possible to travel from East Portland to the race track in fifty minutes. "The completion of the electric line was the one thing needed to make the Vancouver Driving Park a grand success." declared the Independent. 26

The people of Vancouver seemed to enjoy their new electric street 
railway system, though not without a few complaints. Concerning the operation of the cars, the Independent editorialized:

There is entirely too much recklessness displayed by the men in charge of the electric cars, and unless they cease running at such high speed a serious accident will be the result. We are all interested in rapid transit, but it is a foolish and dangerous practice to run the cars through the business part of Main street at the top of their speed. It is generally understood that the road is being operated for the convenience of the public, and is not a playting for motor men and conductors. 27

They also suggested that it might be a wise plan to "take the car-men over to Portland, and give them a lesson in running electric cars before practicing on the Vancouver public." 28

Another lamentable effect of the electrification of Vancouver's street railway was soon noticed by the city's dog owners. The railway track was a pleasant, though highly detrimental, place for the dogs to sun themselves. When the system was horse drawn, the approach of the cars gave them plenty of warning to remove to a safer spot. The speedier electric cars cut the warning time considerably. The Independent recommended that the owners "cause a change in their dog's snoring grounds. "29

Unlike the records of the Columbia Land and Improvement Company, apparently no fortunate accident has occurred which allowed those of the Portland Consolidated Street Railway to survive. Without such data, the financial record of the Vancouver electric line cannot be charted in a detailed way. The newspapers provide some information about it, and the details of the events, both national and international, which precipitated the Panic of 1893 and led to the demise of Markle's enterprises, are also available.

One of the contributing events leading to the Panic of 1893 occur- 
red in 1890 when the Baring Brothers of London failed, resulting in the withdrawal of European capital from the United States. Much of this had been invested in railroads, many of which were overextended beyond market demands. Other factors contributing to the economic downturn were a weakened banking system (centralized in New York), an agricultural depression and declining purchasing power. In February 1893, the Philadelphia and Reading Railroad suddenly went bankrupt and thereafter other businesses began to fall on a daily basis. By the end of the year, 500 banks and nearly 16,000 business had failed. 30

The summer was one of the worst periods in the nation-wide depression when the Erie Railroad and the Northern Pacific collapsed. 31 on August 2, 1893, the Independent announced, "There was a small bank flurry in Portland last week, resulting in suspension of payments by the two Markle banks, the Oregon National and Northwest Trust and Loan..." and then went on optimistically, "The assets of the suspended banks largely exceed the liabilities, and it is thought all will resume business in time." 32 The Oregon National reopened briefly in September and then closed again. The Northwest Trust and Loan remained closed. 33

Markle's financial empire was overextended and crumbled in the face of the demands of his depositors. Kate Markle and their son went to her parents in Pennsylvania where she filed for divorce in early 1894. Later that year he fled Portland owing thousands of dollars. He never returned, nor was the money ever repaid. 34

The Portland Consolidated Street Railway had made some large expenditures in uniting several lines, upgrading the system and purchasing new equipment. The electrification of the Portland and Vancouver steam 
Iine had taken place from March to October 1893.35 There were also several expensive natural disasters which befell them. In November 1893 , the company shops at $23 \mathrm{rd}$ and Burnside, in Portland, caught fire, damaging about thirty cars, and in June 1894, the worst flood on record occurred which destroyed the long trestle across the Columbia River bottom and flooded the power house of the Vancouver electric line, disrupting service for several weeks. 36 In late 1894, the Portland Consolidated Street Railway went into receivership with O.F. Paxton, formerly Markle's attorney, named as receiver. 37

The street cars continued to mun on the schedules required by their franchises, but the financial difficulties they faced forced them to cut back on maintenance and other expenses not absolutely necessary. The Vancouver portion of the Portland Consolidated Street Railway was evidently not paying its expenses at all, 38 and in July 1895, Paxton appeared at a city council meeting requesting permission to suspend operation for a period, not to exceed one year. 39 The council, realizing the hard times the company was facing, agreed to the suspension and the next day, July 2,.1895, the cars stopped running and were soon sent over to Portland. Later that week a crew placed new planks over the tracks and repaired some large holes in the road. 40

The Portland Consolidated Street Railway Company owed the Mercan tile Trust Company over $\$ 400,000$ and in November 1895, the New York firm requested that it be paid within twenty days, or that the property be sold. 41 Paxton and several associates incorporated the Portland Railway. Company in January to acquire the lines of the bankrupt company. 42 Their objective was to overhaul the system for some easterm bondholders 
in order to re-sell it. ${ }^{43}$ As they worked to improve it, no attention was paid to the inactive Vancouver system. Apparently it was not considered to have any profit-producing potential and would just be a drain on the system.

July 1896, the one-year anniversary of the cessation of the railway in Vancouver came and went without any sign of operation resuming. After the first of the year it became self-evident that the Portland Railway Company intended to remove its tracks and forfeit the franchise. The Vancouver city council held a special meeting on January 23,1897 , and passed a resolution instructing the city clerk

...to notify the Portland Railway Company that the city will require that the said company keep Main and 10th streets in repair, as provided in the City Ordinance, and in case the track of said railway is removed that the said company repair said street; and whether rails are removed or not, that said company immediately repair said street to comply with the conditions of their franchise; and the city will hold the company responsible for any damages that might occur by reason of the present dangerous condition of said track, and especially the part extending from Main street on 10th to the Military Reservation. 44

Several days after the council meeting, workers from the Portland Railway Company began taking down the trolley wires. The county treasurer filed a restraining order with the superior court to prevent them from removing all of their property, upon which the county and city had filed liens for unpaid taxes. ${ }^{45}$ The company paid immediately and was permitted to remove its property. Since the city had wamed them that if they did not repair the streets properly, they might be held responsible for any accidents that might occur and the city might repair the streets and bill them for their work, they worked carefully as they began to remove the track. Main Street was paved with cedar blocks and the Portland Railway Company replaced their track with 4" x 12" and 
4" $x$ 6" timbers (four inch side up). By the first week in April the track had been completely removed and planked over. There was some finishing work left to be done, which was completed by the city with the railway company reimbursing it for the work according to a previous arrangement. 46 Seven years after Vancouver's first street railway had begun construction, there existed little physical evidence in the streets to tell it had ever been there.

The legacy of Vancouver's first street railway was in the city's physical shaping and the citizens' understanding of politics, economics, and the newest technology. Vancouver had been bounded on the east by the military reservation and on the west by the Vancouver, Klickitat and Yakima Railroad. As the street railway was built north on Main Street, it tended to reinforce the town's north-south orientation and by opening up Vancouver Heights it aided the settlement of that area much sooner than if it had depended upon the natural growth of the city. The town was no longer limited in area to that which could be easily walked through.

Portland had been a major shopping center for Vancouver citizens for many years. With the development of the Portland and Vancouver Railroad, the travel between the two cities was much easier and increased accordingly. When the street railway in Vancouver was built, it aided in bringing people to the ferry dock so they could go to Portland. The day was foreseen when people would live in Vancouver and work in Portland.

The people of Vancouver had received a lesson in economics with their street railway. The effect on real estate values was apparent and 
the ability to sell land that was accessible due to the railway was demonstrated. With the withdrawal of the Union Pacific and the downturn in the economy this brought about, they learned again of the sensitivity of their economy to national events; this was reiterated during the Panic of 1893. Since the railway was built to provide access to land so that it would be sold, and then subsequently failed because there was not enough travel to support it, perhaps the citizens who observed its rise and demise learned the danger of extending transportation facilities to areas that were not ready to support them.

Vancouver's first street railway system revealed something about the granting of franchises. The recipients of the franchise did not provide the services they had agreed upon for the privileges that they had acquired. There is no evidence that any of the spur lines which had been promised were built, except for the Tenth Street one to the garrison, and the service had ceased prior to the expiration of the franchise. ${ }^{47}$ The street railway promoters had promised much, but fell short of delivery.

Another effect of the first street railway was the citizen's exposure to new technology. With a taste of what it was like to ride in a fast, comfortable vehicle, they began the move away from horse-andbuggy transportation. During the time they had their first street railway, they had also become accustomed to electric street lights and telephones.

As the 1890 s began to draw to a close, the future growth of Vancouver appeared to be stalemated. The decade had begun with a flourish -- statehood, promises of a transcontinental railroad, a street railway, 
a real estate boom and rapid population growth. Now there was no railroad building on the horizon, no street railway and real estate values in decline. A block in Vancouver Heights which had been assessed at $\$ 350$ in 1894 was reduced to $\$ 240$ two years later. ${ }^{48}$ The population was slipping also. In 1880 Vancouver had 1700 people, in 1890,3500 , but by the turn of the century, only 3100.49 Though the nation's economy began to improve with the election of William McKinley in 1896, it would be almost a decade before Vancouver's was reinvigorated with the coming of a transcontinental railroad. Perhaps then the city would be ready for another, more successful, street railway. 
NOTES FOR CHAPTER III

${ }^{1}$ Labbe, Fares, Please!, pp. 79-80.

2MacColl, Shaping of a City, p. 81.

${ }^{3}$ Clarke County Auditor, Deeds and Mortgages, Book 1, passim.

${ }^{4}$ Independent, 6 March 1889.

5 Ibid., 5 June 1889.

6 MacColl, Shaping of a City, pp. 83-84.

${ }^{7}$ Clarke County Auditor, Deeds and Mortgages, Book 10, p. 80.

${ }^{8}$ Ibid., Book 15, p. 113.

${ }^{9}$ Vancouver, Minutes, 4 April 1892.

${ }^{10}$ See Ibid.; and Independent, 19 April 1892.

${ }^{11}$ Vancouver City Council, Ordinance Number 288, (26 April 1892).

12 Independent, 27 April 1892.

13 Ibid.

14 Ibid.

${ }^{15}$ See Clarke County Auditor, Deeds and Mortgages, Book 15, p. 113; and Vancouver, Minutes, 30 April 1892.

${ }^{16}$ Independent, 31 August 1892.

17 Vancouver City Council, Ordinance Number 289, (15 April 1892). ${ }^{18}$ Ibid. 
${ }^{19}$ Clarke County Auditor, Deeds andMortgages, Book 15, p. 269.

${ }^{20}$ Independent, 13 and $20 \mathrm{July} ; 10$ and 31 August 1892.

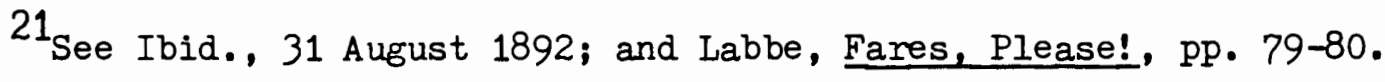

22 Independent, 31 August 1892.

23 Labbe, Fares, Please!, pp. 76, 80.

24 Independent, 31 August 1892.

${ }^{25}$ See Ibid.; and Labbe, Fares, Please!, p. 76.

${ }^{26}$ Independent, 31 August 1892.

27 Ibid., 7 September 1892.

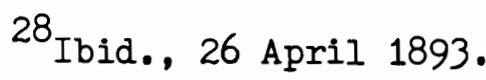

29 Ibid.

30 Harold U. Faulkner, Politics, Reform and Expansion, 1890-1900, (New York: Harper \& Bros., 1959; Harper Torchbook ed., 1963), pp. 141-146.

$31_{\text {Ibid. , p. } 141 .}$

32 Independent, 2 August 1893.

33 MacColl, Shaping of a City, p. 103.

34 Ibid., p. 104.

35 Independent, March-October 1893 passim.

${ }^{36}$ See Ibid., 18 July 1894; and Labbe, Fares, Please!, p. 81.

${ }^{37}$ Labbe, Fares, Please!, p. 81.

${ }^{38}$ Ibid. 
39.Vancouver, Minutes, $1 \mathrm{July} 1895$.

40 Independent, 3 and $10 \mathrm{July} 1895$.

41 Labbe, Fares, Please!, p. 81.

42 Independent, 16 January 1896.

43 Labbe, Fares, Please!, p. 82.

44 Vancouver, Minutes, 23 January 1897.

45 Independent, 28 January 1897.

46 Ibid., 28 January; 4 and 25 February; 11 April; and 20 May 1897.

${ }^{47}$ Clarke County Auditor, Deeds and Mortgages, Book 31, p. 3.

${ }^{48}$ Clarke County Auditor, Tax Rolls of Real Property, 1894, p. 32; and Tax Rolls of Real Property, 1896, p. 252 .

${ }^{49}$ Tattersall, "Economic Development of the Pacific Northwest," p. 78 . 
CHAPTER IV

PROSPERITY AND FRANCHISE SEEKERS: 1905

As the street railway tracks were being removed in Vancouver in early 1897, the nation was recovering from the Panic of 1893. The new prosperity was due in part to the discovery of gold in the Klondike and, according to one historian, by "new technologies which launched new industries in the chemical and electrical fields while invigorating the older iron, steel, and railroad industries; and by an upturn in the general level of prices."1 The election of William McKinley, a Republican, to the presidency in 1896 was reassuring to the nation's business leaders, and the closing years of the century were marked with optimism and confidence in the improving economy. ${ }^{2}$

In the Pacific Northwest evidence of the end of the recession was seen in the renewed railroad construction. The Vancouver, Klickitat and Yakima Railroad was sold by court order to satisfy the claims against it on March 30, 1897, to a newly incorporated firm, the Portland, Vancouver and Yakima Railway Company. ${ }^{3}$ The following year the thirteen and onehalf mile line to Brush Prairie was bringing in 50,000 feet of logs per day to Vancouver, and plans were being made to extend it. ${ }^{4}$ A line to Yacolt (another fifteen miles) was completed in 1902 giving the railroad access to the rich timber there. 5

A right of way between Olympia and Vancouver, held by :the::Portland and Puget Sound Railway Company, was acquired by the Washington and Ore- 
gon Railway Company in early 1901. The new firm was controlled by the Northwestern Improvement Company, composed of Northern Pacific interests. ${ }^{6}$ In April it began building south from Kalama, Washington, and on November 22, 1901, the first train rolled into Vancouver. ' The city finally had a transcontinental connection, though ot was only a spur line and not on the direct route between Puget Sound and Portland. For the train to cross the Columbia River, the ferry at Kalama was still necessary.

The railroads into Portland were controlled by E.H. Harriman with his Union Pacific and Southem Pacific lines entering via the Willamette Valley and south bank of the Columbia River. Since both the Great Northern and Northern Pacific Railroads were thriving in the expanding western business, James J.Hill, who dominated them, determined to build a line from Spokane into Portland which would cross the river at Vancouver. He had been quietly buying up rights of way for some time. In August 1905, the Portland and Seattle Railway Company (later renamed the Spokane, Portland and Seattle) was incorporated; a month later it came out that Hill was its owner. ${ }^{8}$

In spite of Harriman's obstructionist efforts, construction began in the fall of 1905 and proceeded steadily. 9 The Spokane, Portland and Seattle Railway Company had decided to build the bridge at Vancouver, reasoning that permission from the War Department, necessary for an interstate connection, would be more easily obtained for a site previously approved. By using the one pier constructed by the Union Pacific, which was found to be in excellent condition, the company would save from $\$ 60,000$ to $\$ 80,000 .^{10}$ The track was completed on March 11, 1908, and 
the bridge several months later. The ferry at Kalama was discontinued in December of 1908 after twenty-four years of service. ${ }^{11}$ After more than sixty years of rumors, promises and disappointments, Vancouver at last had a direct transcontinental railroad.

The result of this renewed railroad construction in the Vancouver area was to provide a market for the city's lumber mills and employment for its citizens. The Independent reported in 1901 that over 200 men were at work on the extension of the Portland, Vancouver and Yakima Railway line and that all three of the city's mills were busy producing railroad ties. ${ }^{12}$ As the news of Hill's intentions became known in the fall of 1905, much growth was anticipated for Vancouver. Perhaps the citizens recalled how the town grew in 1890 when the Union Pacific began building a line. This time they were not to be disappointed. By the end of the decade, Vancouver had grown from 3100 people in 1900 to 9100.13

Portland was growing very rapidly during this period also. In 1905 it held the Lewis and Clark Exposition to commemorate the centennial of the expedition. Many of those who came to view it became acquainted with the area and eventually settled there. Portland grew from 81,637 people in 1898 to 183,570 ten years later. ${ }^{14}$

With Vancouver poised on the brink of certain growth in 1905, interest was raised in building another street railway. Vancouver's population was growing and, with a railroad bridge across the Columbia River it appeared that the city might gain easy access to the lucrative Portland area. On the 18th of September, the Vancouver city council received two applications for franchises to build and operate street railways 
in the city. 15

The St Helens Public Service Company was headed by a prominent Portland physician, Dr. Henry Waldo Coe. ${ }^{16}$ A resident of Portland since 1891, he had been active in the treatment of nervous and mental diseases and had established, in 1893, the first permanent medical journal in the Pacific Northwest, the Medical Sentinel. In 1905 he was the medical director of the Crystal Springs Sanatorium, a thirteen acre facility located on Mt Tabor in Portland. Coe had been one of the founders of a Kelso bank and served as a consultant for the School for Defective Youth in Vancouver. ${ }^{17}$ He is perhaps best remembered today by Portlanders as the man who gave their city a statue of Theodore Roosevelt. ${ }^{18}$

Dr Coe's company had made large plans. It intended to build a line from Portland to Vancouver and thence along the north bank of the Columbia to Ridgefield, Woodland, Kalama, Kelso, Castle Rock, Silver Lake, and the St Helens Mining District with a branch to the Morton coal fields. Another branch was to go southeast from the mining district to the Columbia near Washougal, and then west to Camas and back to Vancouver. The estimated cost of this line, which would be approximately 200 miles long, including branches, was $\$ 4,000,000.19$

The other company applying for a street railway franchise on September 18 was the Vancouver and Suburban Railway Company. It had been incorporated on that day by seven Vancouver men. Marshall R. Sparks, Ellsworth E. Waite and W.S. Wood were merchants dealing in furniture and hardware; John H. Sugg, W.H. Sugg and Edward M. Green were attorneys; and E.E. Beard was the publisher of the Columbian. No projected routes were announced other than a line on Main Street from the Columbia River 
north to the city limits with others to be added in time. It was reported to be capitalized at $\$ 2,500,000 .^{20}$

With these two franchises pending before the city council, the Independent brought up some of the concerns to be considered in the granting of them:

As could be expected, as soon as it was known that the railroad would come down the north bank, several applications have been to the city council for street railway franchises. No beeter property could be secured at this time than a franchise for a street railway covering the principal streets of the city. They would at once have a good selling value. For instance a franchise up Washington street would no doubt bring a good price in a few years from the Portland Consolidated lines which now lands its ferry at the foot of that street.

There will no doubt be no more important matter come before the council than the granting of these franchises. Good prices are paid by railroads for a right-of-way through private property. Why should not the city get a good price also. Do not grant anyone a franchise they will be selling in a few years for thousands of dollars. The streets belong to the people and if any money is secured for franchises for their use the money should go into the city treasury to help pay off our indebtedness.

On the other hand the city authorities must not become obstructioness (sic). There is not anything that would do more to develop the surrounding country and bring business to Vancouver than connections of local points by cars. If the parties who have these projects in hand mean business they will not expect to secure valuable franchises without paying for them and they will find our city council ready and willing to do business. 21

A street railway would certainly aid in the development of the city as the Independent indicated. Therefore the citizens of Vancouver were eager to assist any company that expressed an interest in building a line. On the other hand, they believed that a franchise for a railway would be very valuable to those who held it, and they wanted to be certain that they would be justly compensated for the granting of it. The city council was warned by the Independent to be particularly wary of companies that were merely interested in obtaining a franchise and then 
selfing it at a profit.

For several months the city council and the two companies negotiated the provisions of the franchise. To be certain that the companies were not just after the franchise for resale, they were required to deposit $\$ 1,000$ on acceptance of the franchise. This was to be refunded as soon as the railway was operating, or forfeited if no work had commenced within six months. The city council also thought that the companies were asking for too much in their franchise requests. The St Helens Public Service Company, for example, asked for permission to build on all of the principal streets of the city and wanted exclusive use of them for five years. The Vancouver and Suburban Railway Company also requested permission to generate and sell power, and to establish a telephone system as part of its railway franchise; the city said that these should be considered as separate franchises. The companies did not want to be required to run their cars on a certain schedule, say every thirty minutes, nor, not surprisingly, did they want to pay a percentate of their receipts (after five years of operation) to the city, 22

The city council stood its ground and refused to grant any overly generous concessions to these franchise seekers. The St Helens Public Service Company changed its application in October 1905, from a street railway franchise to merely asking for permission to run a line through the city on River Road. ${ }^{23}$ This was ultimately denied as the road, ranging from ten to forty feet in width, was considered too narrow.

The Vancouver and Suburban Railway Company continued to re-submit applications for a street railway franchise, though these generally hat few changes in them. Possibly it was merely trying to delay the paying 
of the $\$ 1,000$ deposit that the city was. requiring. It may have been a front for some eastern financiers. At one time it was suggested that the company was being backed by some Pennsylvanians 24 and, since the Portland Consolidated Railway Company had just recently been purchased by interests in New York and Philadelphia for $\$ 6$ million (and tremendous profits for the stockholders), that may have been the case. ${ }^{25}$ Six months after its initial application, the Vancouver and Suburban Railway Company stated that "since they cannot get into Vancouver on their own terms that they will make Camas their terminal" to which the Independent sarcastically remarked, "This is a wise decision on their part. Camas is one of the growing cities on the Columbia River and the people of Vancouver will be pleased to know that it is now to be made the terminal of [the Vancouver and Suburban Railway Company.7"26 No more was heard of the plan, or of the company.

Neither the Vancouver and Suburban Railway Company or the St Helens Public Service Company were involved in real estate speculation in Vancouver. One was merely interested in building an interurban line through the city and tying it in with a much larger system, and the other company was apparently attempting to acquire a franchise in order to sell it again later for a profit. In the summer of 1906, another group of Vancouver men became interested in a franchise. 27 They wanted to have a street railway built in order to increase the value of their property.

The Vancouver Townsite Company had been incorporated in November 1905, by John Elwell, Augustus B. Eastham and Edward M. Ránds. ${ }^{28}$ Elwell owned a real estate business and had been a county clerk and municipal 
judge; Eastham was a dentist; and Rands an attomey. ${ }^{29}$ The company purchased a seventy acre tract of land north of Nineteenth and east of Main Street from S.W. Brown. ${ }^{30}$ Brown was one of the incorporators of the Columbia Land and Improvement Company, and this was a piece of its property which had not been developed. Now, in light of the street railway construction, which appeared imminent, this property seemed to be a good investment.

When the prospects for either of the two companies building their proposed lines began to wane in the spring and early summer of 1906, the Vancouver Townsite Company decided to apply for a franchise. On July 2, the company's representatives appeared at the city council meeting and asked for permission to build a line up Columbia street. ${ }^{31}$ one of the provisions that they requested is that they be allowed nine months to deposit the $\$ 500$ that the city was requiring. The council refused to tieup a franchise for that period without a deposit; the company did not produce the money and, consequently, did not receive a franchise. ${ }^{32}$ It seems likely that the Vancouver Townsite Company was interested in real estate speculation and acquiring a valuable franchise which it hoped to sell for a profit.

In one year the Vancouver city council had received three requests for street railway franchises, none of which had borne fruit. Their experience only reinforced the Independent's wariness about granting a franchise for a street railway. Applicants were not necessarily interested in building a line and of ten asked for too much. 
$1_{\text {Albro Martin, James J. Hill and the Opening of the Northwest, }}$ (New York: Oxford University Press, 1976), p. 461.

2Harold U. Faulkner, The Decline of Laissez Faire, 1897-1917, (New York: Holt, Rhinehart and Winston, 1951; Harper Torchbook ed., 1968), p. 22 .

3 Cheever, The Development of Railroads in the State of Washington, 1860-1948, pp. 105-106.

4 Independent, 3 March and 17 November 1898.

${ }^{5}$ Cheever, The Development of Railroads in the State of Washington, $1860-1948$, p. 105 .

$6_{\text {Ibid. }}$

7 Independent, 28 November 1901.

${ }^{8}$ Charles R. Wood, Spokane, Portland and Seattle Railway: The Northwest's Own Railway, (Seattle: Superior Publishing Co., 1974), p. 23 .

${ }^{9}$ See Ibid., and Independent, 11 January 1906.

${ }^{10}$ Ralph Modjeski, The Vancouver - Portland Bridges; A Report to Mr. Howard Elliott, President of the Northem Pacific Company, and to Mr. John F. Stevens, President of the Spokane, Portland and Seattle Railway Company, (Chicago: H.L. Sherman and Co., 1910), p. ?.

${ }^{11}$ Independent, 26 December 1908.

12 Ibid., 20 June and 3 October 1901.

13 Tattersall, "Economic Development of the Pacific Northwest," p. 78.

${ }^{14}$ MacColl, Shaping of a City, pp. 269, 492. 
15 Vancouver, Minutes, 18 September 1905.

${ }^{16}$ Independent, 3 August 1905.

17 Fred Lockley, History of the Columbia River Valley, Deluxe Supplement, (Chicago: S.J. Clarke Publishing Co., 1928), p. 210.

18 E. Kimbark MacColl, The Growth of a City: Power and Politics in Portland, Oregon, 1915-1950, (Portland: The Georgian Press Co., 1979), p. 661.

${ }^{19}$ Independent, 3 August 1905.

${ }^{20}$ Ibid., 21 September 1905.

$21_{\text {Ibid. }}$

22 Ibid., 5 October 1905 and 22 February 1906.

${ }^{23}$ Ibid., 5 October 1905 and 12 July 1906.

24 Ibid., 28 September 1905.

25 MacColl, Shaping of a City, p. 279.

26 Independent, 22 February 1906.

27 Vancouver, Minutes, 2 July 1906.

28 Vancouver Townsite Company, Articles of Incorporation, (Clarke County Auditor, 11 November 1905).

passim. ${ }^{29}$ Vancouver City Directory, (Seattle: R.L. Polk and Co., 1907-8),

30 Clarke County Auditor, Deeds and Mortgages, Book 60, p. 436.

31 Vancouver, Minutes, 2 July 1906.

32 Independent, 9 August 1906. 


\section{CHAPTER V}

FRANCHISE GRANTED: 1906

The first company to be granted a street railway franchise in Vancouver in the twentieth century, to accept it and to begin construction was backed by Walter H. Moore and Lester B. French. Moore was an entrepreneur involved in a variety of projects. He was one of the four Moore brothers who established a hardware store in Moro, Oregon, in the 1880 s. $^{1}$ They came to own approximately two-thirds of that town, ${ }^{2}$ which, according to one version, had acquired its name from the family. 3 Walter Moore was mayor of Moro from its incorporation in 1899 until 1904, captain of the fire organization, half-owner of a bank, dealer in agricultural equipment, grain and real estate, treasurer of an irrigation company and, with his brothers, was a proprietor of the Moro Opera House. By 1905 he and a brother, Henry A. Moore, moved to Portland where they established the Moore Investment Company. This was a brokerage and mortgage underwriting firm promoting Vernon, a town located a few miles northeast of Salem, Oregon. 4 In 1906 Walter took over the two-year old Oregon Trust and Savings Bank in Portland. 5

Lester B. French already had some railroad experience. He had been associated with street railways in Michigan and Ohio ${ }^{6}$ and was currently the general manager of the Portland Southern Railway Company, which reportedly was interested in building a line from Portland to Salem.? Beyond acquiring rights of way through the Willamette Valley, how- 
ever, this company accomplished very little. ${ }^{8}$

Perhaps Moore and French had become aware of the need and potential for a street railway in Vancouver through E.E. Lytle, who, along with the Vancouver Townsite Company, had unsuccessfully sought a franchise in the summer of 1906. Lytle and Moore had been acquainted in Moro where Lytle served as vice-president of the Moro Commercial Club while Moore was mayor. ${ }^{9}$

On September 17, 1906, Moore and French presented their application for a street railway franchise to the Vancouver City Council and assured them that they meant business. ${ }^{10}$ They said that they were willing to deposit $\$ 1,000$ when they received the franchise and would also accept time limits to begin building and operating the line. ${ }^{11}$

Negotiations with the council continued for several weeks. In early October, French and a Portland attorney, Arthur B. Langguth, who represented him, appeared at the city council meeting with a $\$ 1,000$ certified check and stated that they were ready to proceed with the matter of closing up their franchise. However, only four councilmen were present, and, since five were needed to pass the franchise, the applicants were told that nothing could be done at that meeting. Also in the course of the evening it was revealed that the Portland Railway Company had asked the council to delay the matter of the granting of this franchise, so that they could have time to "go over the situation."12 French and Langguth were understandably discouraged, but were assured by the council that their company would receive a square deal from them. After they had departed, a fifth councilman came in and took his seat. 13 
The city council was now in a good position. There were two companies that appeared to be earnest about building a street railway, rather than merely marketing the franchise after they received it. The Portland Railway Company already had a line from Portland to the ferry dock across the river from Vancouver. Therefore its extension into the city seemed like a logical development. The company backed by Moore and French was apparently solid, as evidenced by its willingness to deposit $\$ 1,000$, something that the other three companies which had applied for franchises in past year had been unwilling to do, and its ready agreement to certain route changes at the suggestion of the council. 14 French's railway experience was also an asset.

Officials of the Portland Railway Company spent some time in Vancouver during the next few weeks, and the Independent announced that its proposed franchise was to be presented to the council on the fifteenth of October. To the disappointment of the citizens and council, it did not apply for one. There had been some criticisms of the company (and its predecessors) for the past several years over the expense of the ride into Portland, thirty-five cents for a round trip, It had been suggested to the council that the application for a city railway franchise might be a good opportunity to get these exorbitant fares reduced. 15 Perhaps the Portland Railway Company realized that it would not have an easy time acquiring a franchise from the city of Vancouver, or maybe it suspected that the system would not pay for a long time. For whatever reasons, the company did not seek a franchise.

The city council's suspicions were aroused when the Portland Railway Company, after indicating interest, did not pursue a street railway 
franchise. Two of the councilmen said that they believed that the franchise sought be Moore and French was for the Portland Railway Company, because "...of the hold up that that company has been maintaining for years against this city, [the Portland Railway Company] did not believe that the council would feel as friendly to them as they would to new people."16 When Moore and Langguth appeared, check in hand, at the city council meeting on November 5th (with all councilmen present), they were delayed once more as councilman Milton Evans inserted an amendment into the franchise stating that they could not sell to, or consolidate with, the Portland line as long as the fare remained fifteen cents or more for a one-way trip to Portland. Langguth spoke up, claiming that it was common knowledge that the Vancouver street railway would not support itself for some time, and that this amendment would seriously hamper the company should it ever need to sell. Evans stated that he had the support of three of the councilmen and no franchise would be granted without this requirement. Under these circumstances Moore said that he could not accept the franchise; he and Langguth departed for Portland. ${ }^{17}$ Moore had called the city council's bluff. The council must have realized that it did not now have anyone asking for a franchise, out of five requests in the past fourteen months. The Evans' amendment was deleted and on November 19, 1906, the franchise was passed by the council. Mayor Augustus Eastham signed his approval on the 22nd, and Moore soon thereafter presented a $\$ 1,000$ check for the required deposit. ${ }^{18}$

The street railway line was to begin at the foot of Washington Street (at the ferry landing), go north to Third, east one block to Main, then north to the city limits. Another line was to run from the 
railroad depot, which was to be constructed a dozen blocks west of Washington, north one-half block to Tenth, and then east to the military reserve. A third section of the line was to run up Washington between Third and Tenth, thereby completing a loop. 19

Construction of the line was required to commence before June 1, 1907, and one and one-half miles of track were to be in operation by September 15 or the franchise and deposit would be forfeited. Several methods of powering the cars could be used, including cable, compressed air, electricity or storage batteries: their maximum speed was set at twelve miles per hour. The cars were to run every thirty minutes between 6:00 $\mathrm{AM}$ and 7:00 PM, and at least every hour until midnight. The maximum fare that could be charged for one continuous ride was five cents and, after eleven years of operation, the company was to pay the city one percent of its gross eamings, to be raised to two percent after the twenty-fifth year. The company was also required to pay ten dollars per month for each freight car that was loaded on city streets. 20

Now that they had the franchise, the Washington Railway and Power Company was incorporated with Moore as president; French, vice-president; Langguth, secretary; and Hugh C. Phillips, a Vancouver banker, was the treasurer. ${ }^{21}$. While awaiting the commencement of construction, the company applied to the city for additional street routes. ${ }^{22}$ A line was to begin at Main and Eleventh and go west to Lincoln. From Eleventh and Jefferson, it was to head north to Thirteenth, then west to Kauffman and north to the city limits. A connection on Washington between Tenth and Eleventh was to be made, and a line from Fifth and Washington was to be constructed east to Reserve Street. 23 
There was some opposition concerning the granting of this second franchise to Moore's company. One question was whether or not it should be required to make an additional deposit. Several of the councilmen thought that another $\$ 500$ should be exacted, but the other members prevailed and the franchise was passed. The mayor vetoed the franchise initially, but after it had been amended to clear up some ambiguities concerning the company's paving responsibilities, it was passed, finally, on June 17th. Except for the streets that it covered, this second franchise was virtually the same as the first one. Construction was to commence before September 15th (the deadline for the beginning of operation for the first part of the line), and it was to enter operation by February 15, 1908.24

While negotiations for the second franchise were proceeding, construction on the first part had begun. The sixty pound rails ordered from A.J. McCabe of Portland had been delivered and were distributed along Main Street, ready to be laid. ${ }^{25}$ The ties had been ordered from the Tenney and Tappendorf mill on Salmon Creek. ${ }^{26}$ Saturday, June 1, at the corner of Twelfth and Main, surrounded by members of the city council, press, county and city officials, Mayor Joseph R. Harvey was presented with a pick and shovel by Moore and proceeded to break ground. 27 The intention was to work north along Main and west on Eleventh to the site of the railroad depot. ${ }^{28}$ The lower business district was slated to be paved that summer and the street railway construction was to be done simultaneously. ${ }^{29}$ A crew of thirty men was put to work and by the second week in June, Main, from Twelfth to Nineteenth, had been graded and was ready for the ties and rails. 30 
The Independent predicted as construction started that "property on Vancouver Heights and other outlying districts should take a jump this week" and reported two weeks later that "many sales are being made" in that area. 31 Apparently, however, Moore and his associates were not interested in building their line for real estate speculation. According to a later owner of the system, it was built with the view of selling it, once the system had become profitable, but prior to its needing any major expensive overhauls such as repaving. 32

In July Moore met with the businessmen of Vancouver and claimed that $\$ 35,000$ had been spent in the street railway construction. He then outlined his company's plans. First it wanted to complete the city system, second, build a line to La Center, and third, one to Orchards. The county commissioners had already been approached with applications for franchises for the county lines. 33 The cost of building the lines was estimated at $\$ 20,000$ per mile in the city and half that outside of it. The Columbian editorialized that "Mr. Moore is a man of ample means and when he undertakes an enterprise he goes through with it. 34

By August 15 the line was completed on Main Street between Eighth and Twenty-fourth, and on Eleventh as far as Jeeferson Street. There had been some delay in the construction through the business district because the city council and street railway company could not agree on how to pave, plank, brick or ballast the space between the rails, but this conflict was gradually being resolved. 35

Unfortunately, though construction was proceeding apace, national events were occurring that would soon halt the building of Vancouver's 
street railway. The nation's economy had improved fairly steadily for the last decade, with only a minor slowdown in 1903. By 1907 bank loans were at a peak but reserves were at minimal levels. 36 The Panic of 1907 commenced nationally in the fall of that year as banks began to fail, but the trouble was evident earlier in Portland. On August 21, Moore's bank, the Oregon Trust and Savings, was closed and went into receivership. 37

Work continued on the railway another nine days. Then on the 31st it was suspended. The company's agents came over from Portland with a "sack of gold" and paid off the laborers, as well as other claims against the line. ${ }^{38}$ It was obvious that the railway would not be in operation by the September 15 deadline, nor would construction on the second part commence by then. In view of these unforeseen circumstances, it was not likely that the city council would take harsh measures, such as revoking the franchise. The council's primary interest was to see that the lines commenced operation, and it did not wish to do anything to hinder the company.

The reaction in Vancouver to the halt in construction was mixed. The Independent said that it was not a good idea to invest in banks "where the officials ... are mixed up in all sorts of promotion schemes" (as Moore had been), because it keeps them too busy to run the bank properly. 39 The Columbian claimed that Moore was "turning over to the receiver of the defunct bank a large part of his private fortune... Under these circumstances and until the bank's affairs are settled he is not in a position to furnish the ready money which is needed to carry on the work of construction." 40 Then it pointed out that all of the 
materials to be used in the line's construction, except the poles and trolley wire, were in the city and suggested two possibilities: either Moore and his associates will eventually build the line, or they will sell it to other capitalists, and "they will not have to do much searching to find buyers." 41

As September went by it became increasingly apparent that Moore was not going to be able to complete the railway. The Oregon Trust and Savings had, as a large part of its assets, bonds in Omaha and Tacoma telephone systems that had not yet begun to operate. The selling of these bonds to the bank had netted the bank's officer's $\$ 20,000$ in illegal commissions. 42 Eventually Moore and his cashier, W.C. Morris, were indicted and convicted. 43

Both the Independent and Columbian urged the citizens of Vancouver to take over the franchise and declared "that the road will pay from the start is frankly admitted by all."44 A group of Vancouver men rose to the challenge and purchased a controlling interest in the Washington Railway and Power Company on the 23 rd of September. 45 Moore remained a part of the company, but the principals were all Vancouver men. State senator Edward M. Rands was the president; realtor John H. Elwell, vice-president; the treasurer, Hugh C. Phillips, was the president of the Commercial Bank of Vancouver and registrar of the United States Iand Office; secretary Matthew M, Connor was a lawyer in Rands' firm; and the general manager, Michl J. Connor, was Elwell's business associate. $^{46}$ On the 21 st of October, two months to the day since the bank failure, construction was resumed. 47

In December the city council extended the deadline by which the 
railway was to be operating to January $1,1909.48$ With the extension, construction proceeded, but apparently it was slow and sporadic. A resolution was introduced at a city council meeting in April by councilman Walter Sparks, asking that the franchise and deposit be forfeited and the track torn up. The company's attorney, Matthew M. Connor, pleaded with the council "with tears in his eyes" not to approve such a measure. 49 He told how much his company had spent on the project and claimed that paving materials were on order. The resolution was referred to the judiciary committee and no action was taken at that time. 50 In light of the Washington Railway and Power Company's slow construction progress and the apparent resulting dissatisfaction by at least one member of the city council, a group of realtors determined to see what it could do to assist the construction of the line. These men, who had the most to gain from the line's completion, formed a Realty Board and persuaded the owners of the franchise to accept bonds for their expenses in the construction completed to that point. ${ }^{51}$ Then it had a form printed in the Columbian soliciting stock from the public:

We the undersigned do hereby agree to pay to the order of T.H. Adams, temporary treasurer for the citizens of Vancouver, Washington, the respective sums set opposite our names for the completion of the street railway within the city limits of the city of Vancouver, Washington, as per dotted lines on the map of said city hereto attached, within 60 days from the date hereof. First payment to be $25 \%$ of the amount subscribed in cash and a note for the remainder, $25 \%$ of the same to be paid in 30 days and the balance on or before 60 days from the date of this instant. When the road is completed, we are to receiye stock non-assessible for this amount of our subscription....

Stock was to be issued only for the amount of actual costs of construction, operation and equipping of the road. The subscribers were 
to elect their own officers, and, unless $\$ 20,000$ was guaranteed for the construction of the railway, as shown on an accompanying map, the money and note were to be returned within thirty days. 53

This call for the citizens' support was evidently ineffective. Three weeks after the solicitation, councilman Sparks delivered an ultimatum to the Washington Railway and Power Company: either it give some definite statement as to its plans at the next council meeting, or he would again push for the passage of the resolution asking for the revocation of the entire franchise. ${ }^{54}$ At that next council meeting the company pleaded for, and was granted, yet another week to make good. Rands said that negotiations for the sale to outside capitalists were progressing and in one more week the line "should be in the hands of capitalists who would complete the work at once." 55

On June 1st, Rands, William J. Patterson of Baker City, Oregon, and Alvadore Welch of Portland, filed articles of incorporation in Vancouver for the Vancouver Traction Company. 56 Patterson had been involved in a number of enterprises in Baker City, including a paint and paper store, a furniture business and mining. He owned an undertaking business and was the county coroner. 57 Welch was a "born promoter of utilities" 58 and had been active in the building of power plants and railways throughout Oregon and Washington. 59 He was the local agent of a large Philadelphia banking company, Rhodes, Sinkler and Butcher, which owned numerous power plants and street railways in the Willamette Valley, Walla Walla and Boise. ${ }^{60}$ He had also been instrumental in the construction of the Oregon Electric line between Portland and Salem. ${ }^{61}$

The Vancouver Traction Company purchased the Washington Railway 
and Power Company for $\$ 125,000$ on the 10th of June and assumed its outstanding claims of $\$ 37,000 .^{62}$ Then the new company was mortgage to the Merchant's Savings and Trust of Oregon for $\$ 250,000$ with interest at five percent per annum. 63

James B. Kerr, a Portland lawyer representing the Vancouver Traction Company, appeared before the city council on June 15th and requested a few minor route changes. Kerr was a familiar figure in Vancouver as he had negotiated the rights of way for the Spokane, Portland and Seattle Railway several years before. He had since teamed up with Charles H. Carey to form the law firm, Carey and Kerr. He told the council that he had personally sent a draft for the street cars. The council readily granted his requests and, by the months end, construction had resumed. 64

In July the Vancouver Traction Company received permission from the county commissioners to extend its line beyond Vancouver Heights, east to St John Road. A site was chose there to build its car barns where the street cars could be maintained and stored when not in use. ${ }^{65}$ (The building the company erected for this purpose still stands at the northwest corner of Thirty-third Street and St John Road.)

By September 1, 1908, the line was completed through the city. The only delay now in the commencement of operation was the arrival of the street cars. The cars were to be at least five feet longer than those used on the Portland - Vancouver run and would hold sixty people. Each car was powered with twin 50 horsepower motors to carry them over the tracks at a good rate of speed, and they had "natural wood finished interiors with a ceiling of delicate tinted green."66 They arrived on 
the $23 \mathrm{rd}$ and the line went into operation three days later. 67

On that first day, the cars were decked out with optimistic signs: "Beginning of 100 Miles of Suburban Electric Lines in Clarke County," "30,000 for Vancouver in 1910," and "Dawn of a New Era for Vancouver and Clarke County."68 Loaded down with city and company officials, the celebration committee, and the city band, the cars departed from the courthouse at three $\circ^{\prime}$ clock and headed towards Main Street. After running south to the ferry, they turned north to Vancouver Heights and then back to Fifth where a stage had been constructed out of dry goods boxes. Short speeches were made by Mayor Edwin Green, Welch, Kerr, Patterson, and others, including Walter H. Moore, the man who had begun applying for the franchise two years previously. With . the completion of the ceremonies, the system was then opened to the public for free rides for the remainder of the day. 69

It had bee thirteen years since Vancouver had had a street railway. From the time that Moore had been granted the franchise until this system had begun operation, twenty-two months had passed, months in which the citizens of Vancouver were uncertain that they would ever have a street railway. Fortunately, with Welch and Patterson, solid financiers had been found; the railway was operating and there were promises of future extensions. 


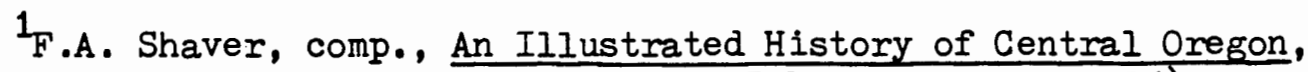
(Spokane, Washington: Western Historical Publishing Co., 1905), pp. 554-555.

2 Ibid., p. 445 .

3 Lewis A. McArthur, Oregon Geographic Names, (Portland: Binfords and Mort, 1928; 2d ed., 1944), p. 336 .

${ }^{4}$ See Shaver, History of Central Oregon, pp. 554-555; and Oregon and Washington Gazetteer and Business Directory, (Seattle: R.I. Polk and Co., 1903-1904), passim.

5 MacColl, Shaping of a City, p. 354 .

${ }^{6}$ Vancouver Weekly Columbian, 22 November 1906. (hereafter cited as Weekly Columbian).

7 Oregon and Washington Gazetteer and Business Directory, (Seattle: R.I. Polk and Co., 1905-1906), p. 384.

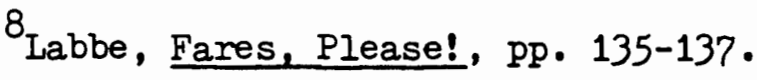

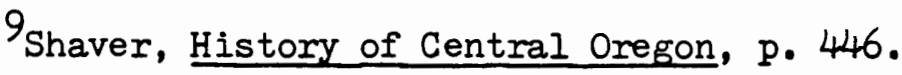

10 Vancouver, Minutes, 17 September 1906.

${ }^{11}$ Independent, 20 September 1906.

12 Ibid.

13 Ibid.

${ }^{14}$ Ibid.

15 Ibid., 11 October; 23 August; and 28 September 1906. 
${ }^{16}$ Ibid., 22 November 1906.

${ }^{17}$ Ibid., 8 November 1906.

${ }^{18}$ Ibid., 22 November 1906; and 17 January 1907.

$19_{\text {Weekly Columbian, }} 17$ January 1907.

${ }^{20}$ Ibid.

${ }^{21}$ Independent, 3 January 1907.

22 Vancouver, Minutes, 6 May 1907.

${ }^{23}$ Independent, 27 June 1907.

24 Ibid., 23 May; 20 and 27 June 1907.

25 See Ibid., 30 May 1907; and Weekly Columbian, 11 April 1907.

${ }^{26}$ Independent, 30 May 1907.

27 Weekly Columbian, 6 June 1907.

${ }^{28}$ Independent, 6 June 1907.

$29_{\text {Weekly Columbian, }} 6$ June 1907.

${ }^{30}$ Independent, 13 June 1907.

${ }^{31}$ Ibid., 30 May and 13 June 1907.

32 M.D. Spencer, Report on the Washington - Oregon Corporation and Independent Electric Co., Puget Sound Power and Light Collection, University of Washington, 1914, p. 105. (herafter cited as Spencer, Washington - Oregon Corporation).

33 Weekly Columbian, 25 and 4 July 1907.

${ }^{34}$ Ibid., 25 July 1907.

35 Ibid., 15 August 1907. 
36 Peter d'Alroy Jones, The Consumer Society, A History of American Capitalism, (London: Penguin Books, 1965; rev. ed. of America's Wealth, New York: MacMillan Co., 1963), pp. 246-247.

37 MacColl, Shaping of a City, p. 354.

38 Independent, 5 September 1907.

39 Ibid., 22 August 1907.

40 Weekly Columbian, 5 September 1907.

${ }^{41}$ Ibid.

42 MacColl, Shaping of a City, p. 354.

${ }^{43}$ See Ibid., p. 355; and Oregonian, 2 April 1910.

44 Weekly Columbian, 19 September 1907.

${ }^{45}$ Independent, 26 September 1907.

${ }^{46}$ Vancouver City Directory, (Seattle: R.L. Polk and Co., 1907-1908), passim.

47 Weekly Columbian, 24 October 1907.

${ }^{48}$ Independent, 19 December 1907.

${ }^{49}$ Ibid., 9 April 1908.

${ }^{50}$ Ibid.

51 Ibid., 16 April 1908.

52 Ibid.

53 Ibid.

${ }^{54}$ Ibid., 7 May 1908.

55 Ibid., 14 May 1908. 
56 Vancouver Townsite Company, Articles of Incorporation, (Clarke County Auditor, 1 June 1908).

57 H.K. Hines, An Illustrated History of the State of Oregon, (Chicago: The Lewis Publishing Co., 1893), pp. 316-317.

58 Randall v. Mills, "Early Electric Interurbans in Oregon. 2. The Oregon Electric and Southern Pacific Systems," Oregon Historical Quarterly 44 (December 1943), p. 390.

59 Oregon Journal, 28 September 1913.

${ }^{60}$ Labbe, Fares, Please!, p. 122.

61 Oregon Journal, 28 September 1913.

62 See Clarke County Auditor, Deeds and Mortgages, Book 7, p. 174; and Independent, 4 June 1908.

${ }^{63}$ Clarke County Auditor, Deeds and Mortgages, Book 74, p. 23.

64 Independent, 18 June; 1 October; and $2 \mathrm{July} 1908$.

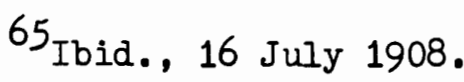

66 Weekly Columbian, 3 and 24 September 1908.

67 Independent, 1 October 1908.

68 Ibid., 24 September 1908.

${ }^{69}$ Ibid., 1 October 1908. 
CHAPTER VI

THE VANCOUVER TRACTION COMPANY, 1908 - 1911

From its commencement of operation in September 1908, the Vancouver Traction Company enjoyed a brisk business. People were pleased with the easy access it provided to the business center of town, and also with the pleasure of riding it. Sunday was a particularly popular day with a ridership averaging one-third more than on weekdays. 1 Through the end of December the line averaged over 25,000 passengers per month. Total revenues from operation during this period were $\$ 3,977.35$; this was greater than the operating expenses of $\$ 3,462.77$ by $\$ 514.88 .^{2}$ The street railway was apparently successful. The Spokane, Portland and Seattle Railroad bridge, crossing the Columbia River west of Vancouver's business district, was completed in July 1908, and in November the trains began to run regularly into Portland. 3 Both the Portland Railway Light and Power Company (which had formed as a result of the merger of Portland lines on May 2, 1908) and the Vancouver Traction Company had expressed interest in using the bridge to run their cars between the two cities. 4 However, both companies had problems because of their track gauge. The Vancouver line was standard gauge and, though it would have been able to use the bridge's tracks to cross the river, it would not have been able to use the street railway line which ran into downtown Portland from there because the latter was a narrow gauge "bastard" line. 5 The street cars could 
have remained on the track into Portland, but then would not have had access to the North Portland area and would have had to electrify that part of the line, too. The Portland Railway Light and Power Company had a similar problem. Its narrow gauge cars would not be able to cross the bridge without its being modified and, once on the Vancouver side, a narrow gauge track would be required. 6

The difficulties of either line crossing the Columbia could probably have been sorted out, but the railroad itself was not in favor of it. Likely the railroad preferred to keep the bridge for its own use so it need not be concerned with the scheduling of the street cars, electrification of the rails, or hanging of the trolley wire. Besides, permitting a street car to carry passengers (and possibly freight) between the two cities would cut in on its business.

The completion of the railroad and the building of the street railway system had aided Vancouver's growth and now residents of areas on the outskirts of the city were expressing an interest in becoming a part of it. If they did join the city they would likely get improved streets and sidewalks, but another inducement was seen in light of the Vancouver Traction Company's stated goal of building 100 miles of line in the vicinity. Under the franchise with the city, the maximum fare that the company could charge was five cents; outside of the city limits it could set its own rates.? Therefore, if these communities near the city of Vancouver were to join it, they would not be at the company's mercy when it came to setting fares. In April 1909, the size of the city was increased threefold as a result of a special election ( 615 for the additions, 116 against them). From Vancouver Heights north to 
beyond Rice Road (now 39th), Lay's Addition on the northwest of the city to the Burnt Bridge Creek bridge, and the area south of it on the east side of the military reservation, including Irvington and Harney Hill, were all added to the city. 8

When the Vancouver Traction Company worked to complete the line in the summer of 1908 , its primary objective was to get the cars running. Now that the line was operating, it could carry out some improvements to make the system more reliable and profitable.

The power to operate the street cars when the line commenced running was purchased from Portland General Electric (which had purchased the Vancouver Electric Light and Power Company in January 1906). 9 If the Vancouver Traction Company produced its own electricity, this would provide a steadier, more reliable, and perhaps cheaper source of power. In April 1909 the company announced that it had bought a 315 horsepower dynamo, capable of generating 250 kilowatts of electricity, from the Willamette Valley Electrical Company. ${ }^{10}$ This was a Portland firm in which Hall and Welch were involved. The dynamo was to be installed along the water front at the Pittock and Leadbetter Lumber Mill where it would run from steam generated by the burning of sawdust and other refuse. The lumber company would use some of the power generated for its own needs, but the majority of it would go to the street railway. ${ }^{11}$ Within months of the line's commencement of operation, the company began to extend it on the city streets. Portions were added to the line so that the cars might make a loop on Columbia and Main streets, instead of having to wait for one another to clear the track. Rails were laid on Eleventh west to the Spokane, Portland and Seattle Rail- 


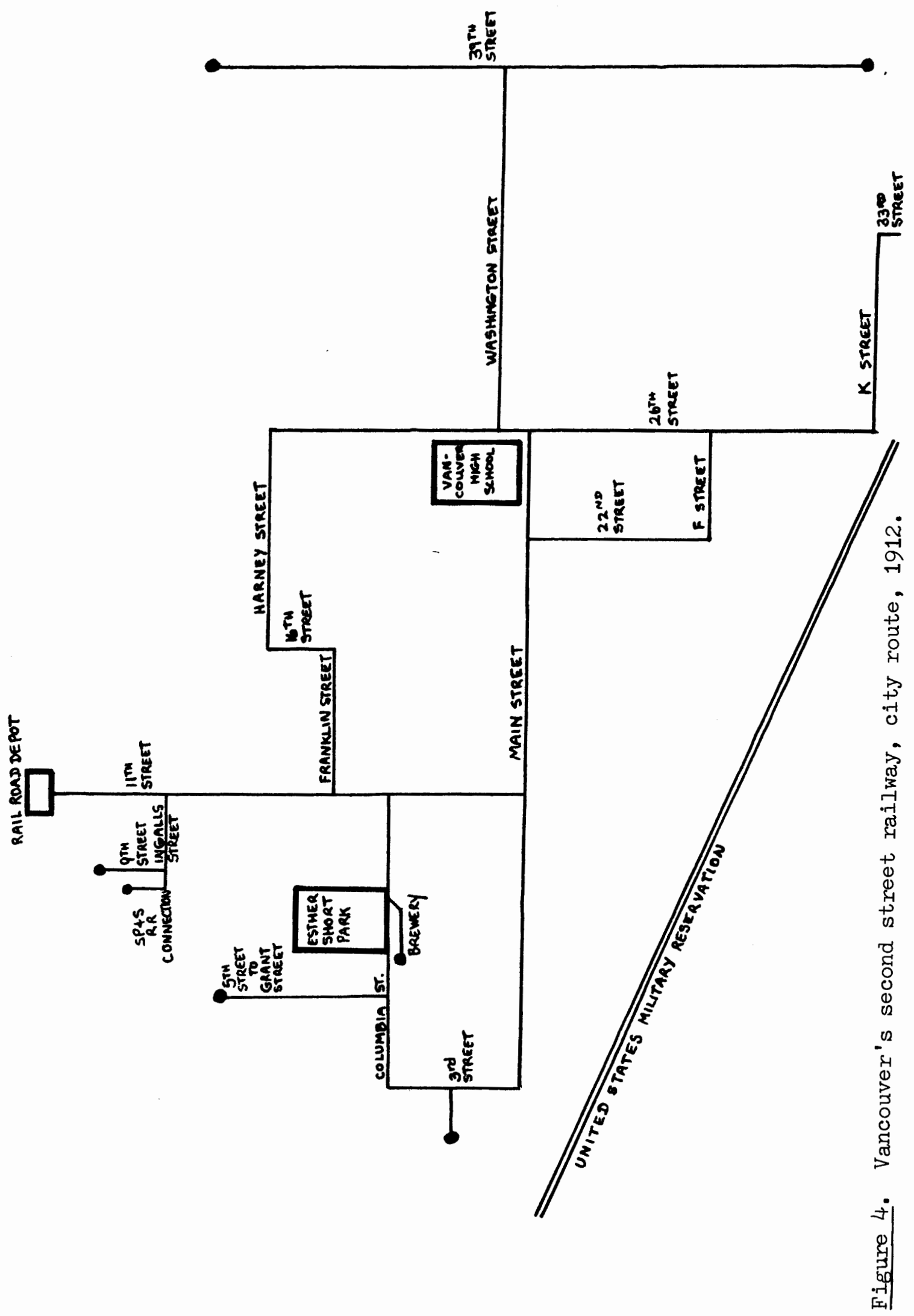


road depot, and another line was extended northeast to Minnehaha to provide access to the people living in that area. ${ }^{12}$ Later, tracks were built on Seventh Street between Washington and Columbia to accomodate freight shipments to the brewery (these are still visible). 13

The Vancouver Traction Company not only improved its city lines, but also began to seriously consider interurban possibilities. Two months after the line began running, President Patterson, who was in the city inspecting the line, announced that the company had been offered inducements to build its line east six miles to the community of Orchards. ${ }^{14}$ During the next few months a route was surveyed and, in March 1909, citizens of the community and Vancouver Traction Company officials held a meeting at the Orchards Grange Hall to discuss the building of the line. ${ }^{15}$ Since the line was to run outside of the city limits (even when the proposed annexation was approved), a franchise from the city would not be required. The county approval was easily obtained since the proposed route was not on any county roads, but rather on private rights of way which the company would purchase. These could likely be obtained at little or no expense because the land owners realized the value that an interurban line would add to their property.

What the company needed to build the line was money. The people living in the area were the ones who would benefit the most from the line by the access it would provide to the city, by the transportation it would furnish their farm products and by the increased valuation of their land. Therefore the company announced that when a $\$ 10,000$ bonus was raised, it would commence construction within thirty days. Half of 
this money was to be paid to the company when the road was 50 percent built, the remainder was due upon its completion. 16

Various community and business groups, including the Vancouver Commercial Club, worked to help raise the money. The Independent published an article which claimed that there was an epidemic of "electric fever." This "spirit of improvement" which had struck the county as well as the city was never fatal, and "many residents of Orchards [were] attacked while others are immune." Once the line was built to Orchards, the Independent asserted, "there will be no stopping it from going right along, for the farther out you get the more people need it."17 One timber firm near Hockinson (about five miles northeast of Orchards) was offering $\$ 5,000$ to have the line extended to it, while another volunteered to lay ties, rails, and build bridges once the grade to it was completed. ${ }^{18}$ As a result of the boosters' efforts, pledges of money came trickling in. By the middle of June, $\$ 8,000$ had been raised. On the $22 \mathrm{nd}$ it was announced that the whole $\$ 10,000$ had been pledged and that construction was to begin immediately. ${ }^{19}$

To build the line to Orchards, the Vancouver Suburban Railway Company was incorporated on June $22,1909.20$ Two of the incorporators, John W. Sifton and Omar C. Spencer, lived in Portland, Bert Yates, the third one, was from Vancouver. Sifton, the president, was a physician, and Spencer, who had been the secretary of the Vancouver Traction Company, was a lawyer with his office in the same building as James Kerr. Yates was also a lawyer, in partnership with his father, William E. Yates. $^{21}$ Welch was on the board of directors, as were fellow Portland citizens, C.E. Moulton, who was the president of the Lawyers Abstract 
and Trust Company, and J.H. Murphy. ${ }^{22}$ Another member, James Granville Kidwell, lived in Walla Walla where he directed his extensive cattle holdings in Montana, Idaho and British Columbia. 23 The company was reincorporated under the name of the Clarke County Railway Company several weeks later. 24

Also on the 22nd of June, the Clarke County Development Company was incorporated by Sifton, Spencer and Yates. On its board of directors were Vancouver Traction Company president, Patterson, and two Portland men, Edward W. Hall and Russell B. Caswell. 25 Hall had been associated with Welch in the Willamette Valley Electric Company, and Caswell was a partner with Murphy in the real estate business. ${ }^{26}$ In 1911 Kidwell, who had moved to Portland the previous year, Caswell and Murphy joined to gether in a live stock dealing firm. ${ }^{27}$ Like the Clarke County Railway Company, the Clarke County Development Company was capitalized at $\$ 150,000$ and the life of the corporation was to be fifty years. 28

These two new companies were closely tied to the Vancouver Traction Company as can be seen by the people involved. Patterson, Welch and Spencer were all officers in the former company. The Clarke County Railway Company was formed to construct the line which it would then lease, at \$9,000 per year, to the Vancouver Traction Company. 29 Evidently there was some advantage to doing it this way; perhaps if it became necessary to ask for a fare increase in the city, those granting such an increase would only be able to consider the profitability of that certain part of the line.

The Clarke County Development Company was, as its name suggests, 
real estate development firm. For $\$ 30,000$ it acquired about 180 acres of land in the Calder donation land claim two miles east of Orchards from Horation N. Price and A.R. Pickett with the view of developing it and extending the railway to it. 30 Ten thousand dollars were to be paid on January $1,1910, \$ 10,000$ in July, and the remainder, including 6 percent interest, was due by the first of January, 1911. 31 It was decided to name the community after the company's president, Sifton. The streets were laid out and named after various board members: Kerr, Hall, Alvadore avenues, and Moulton, Russell and James streets. 32 Caswell and Murphy opened a real estate office in Portland, and one in Vancouver at 712 Main Street, in August 1909 to sell real estate and to try to attract capital, factories and industries to the area. 33

With the financial arrangements settled, the task of building the line soon started. First the route had to be carefully selected. From the car barns the line was to run due east, crossing Burnt Bridge Creek at about one-quarter mile, continuing east for another mile and then turning northerly for the remainder of the distance. 34 For most of this distance the line was to run just a few hundred feet north of Fourth Plain Road. The rights of way were acquired from the land owners for one dollar each in most cases. 35

The construction work began in early August about two miles east of the car barns. Fifteen thousand ties were ordered from the Harvey Milling Company but as these could not be delivered until the bridge was completed across Burnt Bridge Creek, another 3,500 were ordered for the east end of the line so that the absence of them would not restrict the construction. 36 The contract for the 800 foot bridge was awarded 
W.D. Smith, a Vancouver contractor, for $\$ 7,795.80$. Construction of it was to commence immediately and to be completed in two months. 37

On Sunday, March 24, 1910, the line was opened from the car barns to Jaggy Road (now N.E. Andresen Road) and many people crowded the cars to try it. Unfortunately, there was a problem with a lack of power and many of those who came to ride were not able to do so while others were several hours on the ride. 38

On May 15th the line to Orchards was officially opened. A forty minute service was instituted and the work on the line to Sifton was continued with diligence. This construction was delayed due to a hold-up in the delivery of the trolley wire, but on June 30th service to Sifton began. 39 Between the car barns and the end of the line a number of regular stops were established. Most of them were named after the land owners, upon whose property they were located, and the first one after the car barns was the Falk station, followed by Stapleton, Jamison, Sparks, Jaggy, Roney, Bonzo, Hartfield, Parkway, Orchards, Gehr and Sifton. 40 (These were to vary a bit through the years.) The fare to ride the street car from the Vancouver ferry to the end of the line at Sifton was fifteen cents, one-way. ${ }^{41}$

With the expansion of the line, more cars were needed. In late June 1909, a third car had been delivered to the company and was put on the recently completed Eleventh Street line. At the end of the year the cars were all sent over to Portland, one at a time, to have their brake systems changed to air brakes. In July 1910, with the completion of the line to Sifton, two more passenger cars were ordered. By the fall of that year traffic had increased so much during the busy hour 
between 5:00 and 6:00 PM that a tripper, or trailer car, was added on the run between the ferry and car barns. 42

The Vancouver Traction Company had been primarily concermed with providing transportation for people. In July 1910, it determined to expand into the freight business and accordingly ordered a freight car. The car, which arrived in September, was equipped with two powerful motors at each end for a total of 160 horsepower. It was thirty-five feet long and capable of hauling twelve loaded cars, or thirty tons. Freight was received at the company's depot, 712 Main Street, and then delivered to Orchards or Sifton on its twice daily run after it commenced operation later that month. 43

The completion of the line influenced the growth of Vancouver, Orchards and Sifton. The northeast section of Vancourer saw more than fifty residences constructed in 1910, principally due to the car line making that section of the city accessible. Depending on who was asked it was asserted that property values in Orchards had increased between 50 and 600 percent since the construction of the line to it. It was claimed that $\$ 100,000$ had been spent in Orchards in $1910 .^{44}$

The line to Orchards also made it possible for several events to be held there that otherwise would have likely taken place elsewhere. Shortly after the line began its regular run, the County Veteran's Association had its annual meeting in Orchards. The fact that the association's president, J.A. Keaton, was one of Orchards' most active boosters must have aided in the scheduling of the meeting there. ${ }^{45}$ And in August 1910, Thomas Burke, candidate for the United States Senate from Seattle, delivered a speech in Orchards at a harvest picnic. The 


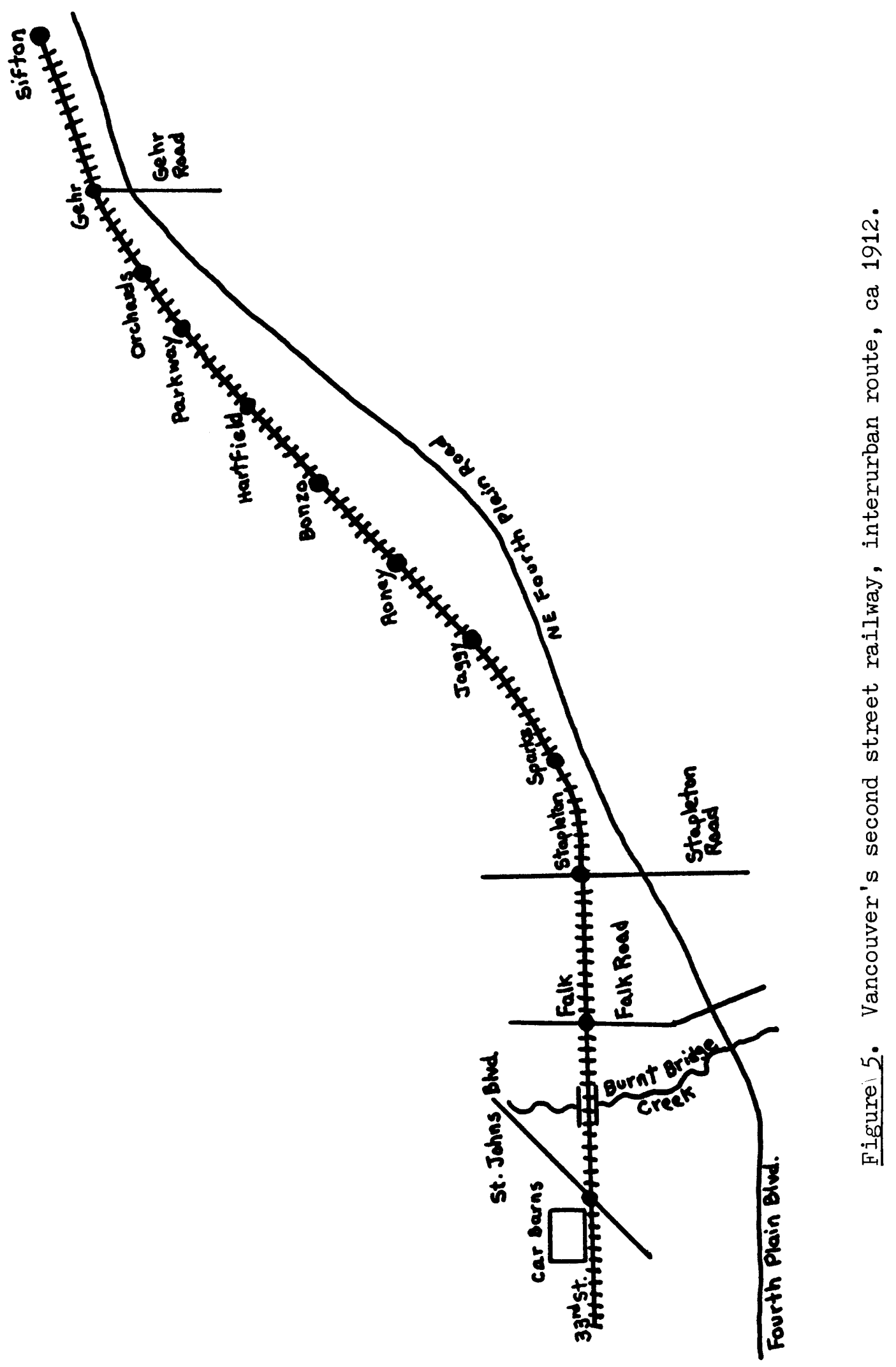


town was planning to construct a $40^{\circ} \times 80^{\prime}$ athletic building in which it could schedule future meetings. 46

Sifton appeared to be a place of opportunity for the enterprising. Caswell predicted that the site would have much growth and eventually become a business center. ${ }^{47}$ An advertisement in the Columbian touted the "Unusual Openings at Sifton" and described the fine new depot and freight warehouse that had just been completed there. Some of the splendid opportunities available to the energetic person, the advertisement said, were for a blacksmith, livery and feed stable, hotel, restaurant and confectionery, and lumber yard. 48 "Opportunity" in reference to Sifton at that point in its development may well have been considered a euphemism for an empty place.

Sifton grew slowly. The city directory for Vancouver, 1914-1915, was the first to list its population; it claimed that there were only fifty people living there. ${ }^{49}$ Sales of land were slow also. In 1910 the Clarke County Development Company sold just over $\$ 3,200$ worth of land in Sifton. The next two years the figures were $\$ 8,600$ and $\$ 7,600$, respectively, for a total of not quite $\$ 20,000$ for the first three years. With payments totalling over $\$ 30,000$ due in the first year and one-half, the company was clearly not profitable. 50

Though Vancouver's citizens welcomed the street railway, there were several aspects of it which did not please them. In the summer of 1908 , as the company was struggling to get the line operating, the city allowed it to lay down planks between the rails, instead of Belgian Blocks (cut stone, usually granite), with the understanding that the planks would be replaced whenever the city required it. ${ }^{51}$ Again in May 
1909 when the Vancouver Traction Company was applying for a franchise

for a short section of Eleventh Street on which it was extending its

line, the pattern was repeated. The Independent commented:

On Eleventh Street are the Street car tracks of the Vancouver Traction Company and the ordinance for the paving of this street provides for the paving of these tracks with Belgian blocks, as they should be. Nevertheless Attorney James B. Kerr who has hypnotized Vancouver councils for several years past was on hand and almost immediately after the passage of the ordinance providing for the Belgian blocks he got permission to address the council and after making a few mysterious passes with his hands over the heads of the council and by using a few soothing words in his easy and flowing manner he prevailed upon the council to grant his company permission to violate the very ordinance which but a few moments before they had passed, by the laying of planks between the rails of their street car fine instead of Belgian blocks as provided in the ordinance....

It was recognized, however, that paving between the street railway tracks was quite expensive. For the company to construct its Eleventh Street line in a cement foundation with Belgian blocks would cost it $\$ 10,000$, and, as the Independent pointed out, "This money would permit quite an extension of the line into the country and would be of quite as much benefit to the city as the laying of pavement on this street."53 The city council, however, resconded its former action giving permission to allow planking on Eleventh Street, and required it to be paved. The company ordered 120,000 blocks from St Helens and soon complied. 54

Unfortunately, much of the street railway system had been constructed at minimal expense. The Main Street line was in poor shape within a year and one-half of its construction. Water collected underneath the planks and ran down the hill, and property owners along the street were concerned that the pavement might be undermined and cave in. Throughout the late summer and fall of 1910, Main Street had to be 


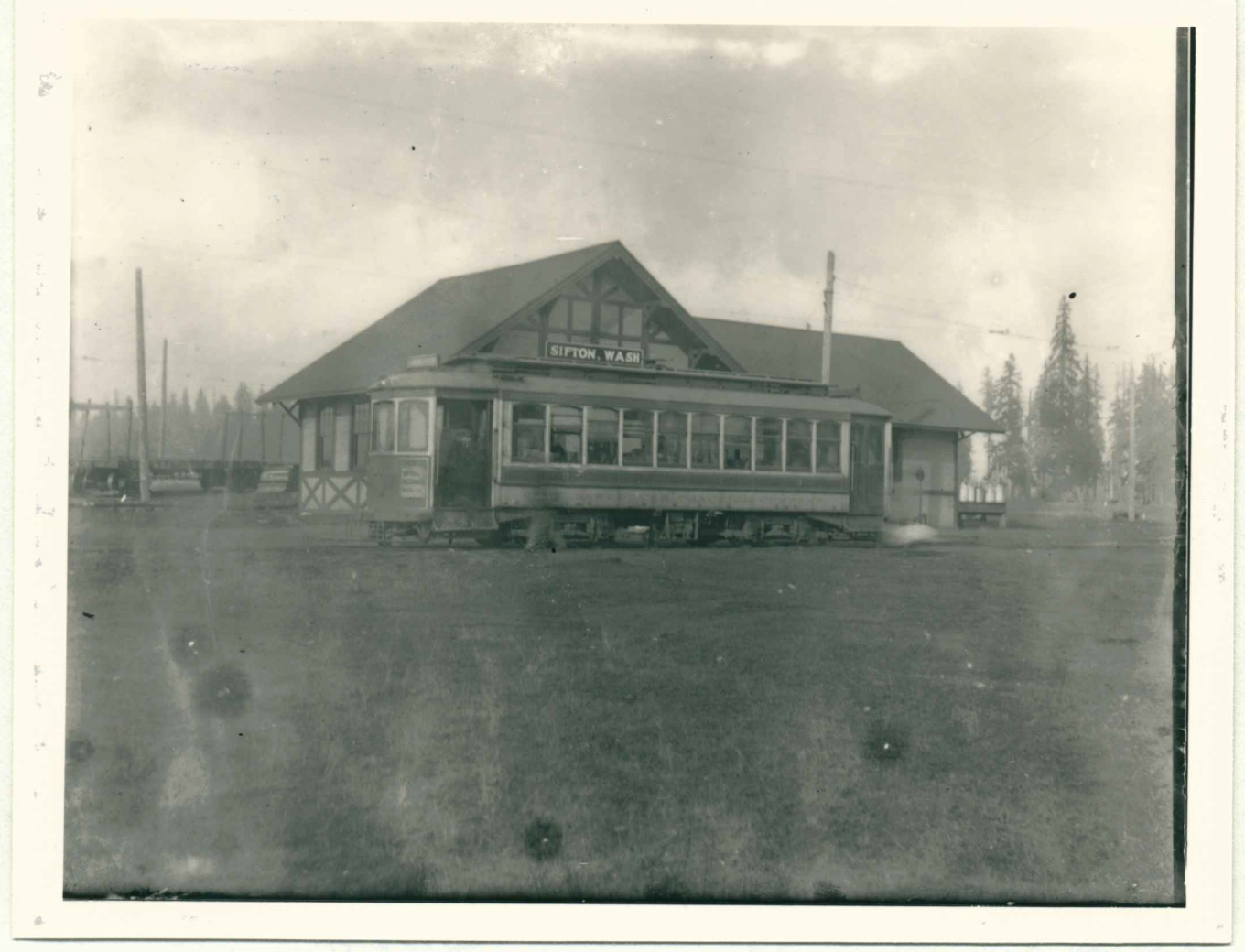

Figure 6. Sifton depot, 1911-1915.

torm up and the track relaid, an operation that was costly to the company and very annoying to the businesses located located along it. 55 In a study of the street railway system completed in January 1914, M.D. Spencer stated that "The road is cheaply constructed ostensibly for the purpose of sale."56 He claimed that most of the track was poorly ballasted, which led to increased wear on the rolling stock and decreased car speed, and that some of the rails were not of the standard sixty pound steel gauge, but rather of lightweight fifty-six pound iron gauge. The trolley wire used $(\# 00)$ was fine for the city line, but a heavier grade $(\# 4 / 0)$ should have been used on the interurban section because the voltage dropped with the distance. ${ }^{57}$ A result of this poor construction was that the line had difficulty maintaining its schedule and there were many complaints from Vancouver citizens con- 
cerning this. 58

In its first two years of operation the Vancouver Traction Company was apparently reasonably successful. From October 1908 through December 1909 the average monthly transportation revenues were $\$ 1,904.14$ against transportation expenses averaging $\$ 1,156.40$ for a monthly profit of about $\$ 750$ (see figure 7). In 1910 the revenues averaged $\$ 3,484.12$ against transportation expenses of $\$ 1,665.25$ for an average monthly profit of about $\$ 1,800$. In July 1910 over 9,000 passengers rode the line. 59

In spite of the annual surplus of revenue amounting to $\$ 20,000$ in 1910, the Vancouver Traction Company was not doing that well financial1y. The annual interest on its mortgage to the Merchants Saving and Trust of Oregon was $\$ 12,500$, and the lease of the Sifton line from the Clarke County Railway Company was $\$ 9,000$ per year; these two expenses were enough to consume the surplus transportation revenues. There had been pressure to improve the service and it was apparent that before too long some expenditures would have to be made to repair the tracks, an expensive undertaking as the owners were only too well aware. The property that the Clarke County Development Company was promoting in Sifton was selling very slowly.

Those who knew that the Vancouver Traction Company was eaming enough to meet operating expenses, plus pay the interest on its mortgage, and probably no more than that, were likely not surprised to learm in late 1910 that it was to be sold to a firm which owned a number of public utilities in Washington and Oregon. On the second day of 1911, the title to Vancouver's street railway and the Clarke County 


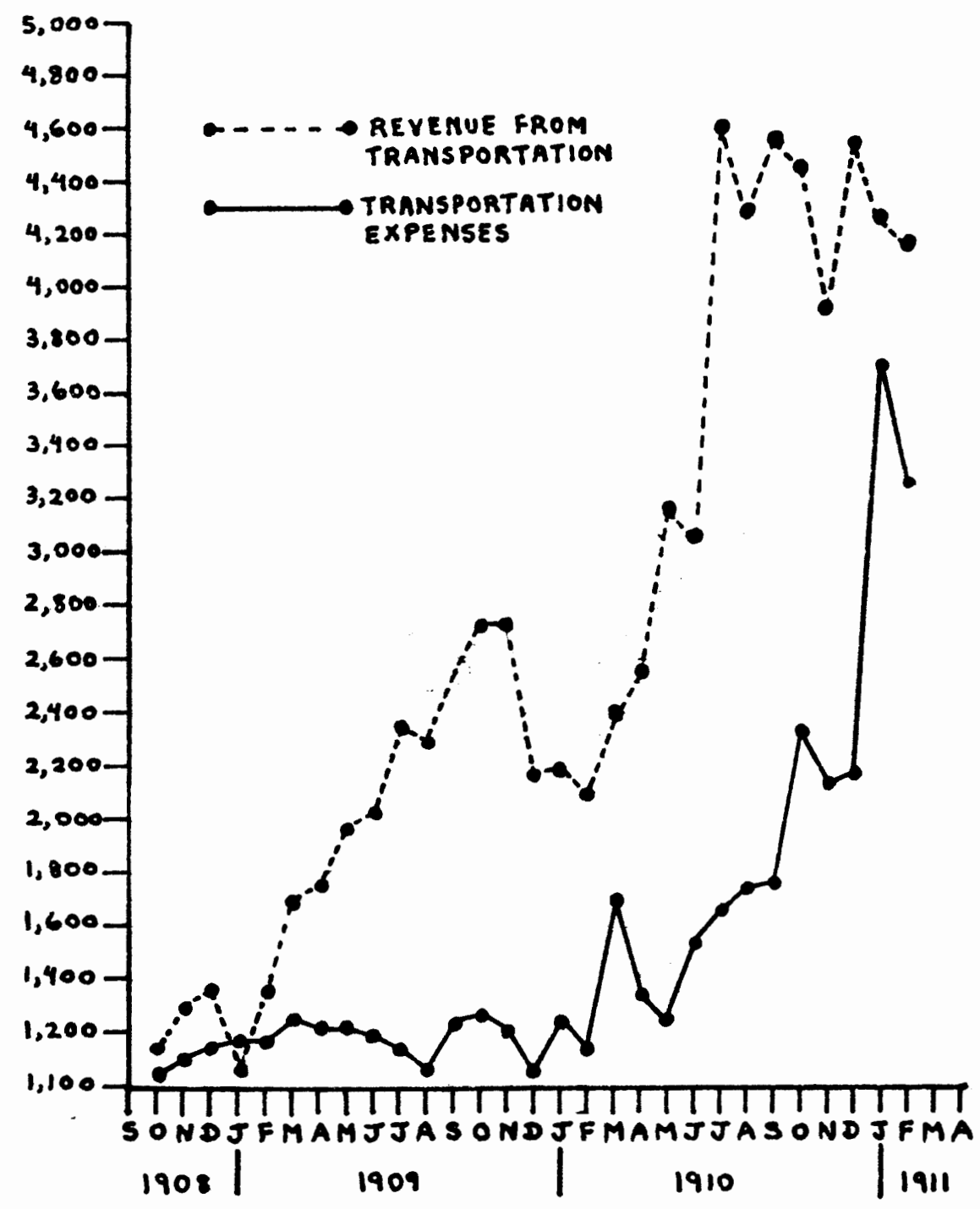

Figure 7. Vancouver Traction Company, profits and losses, 1908-1911. 
Railway Company were transferred to the Washington - Oregon Corporation. 60 
NOTES FOR CHAPTER VI

${ }^{1}$ Columbian, 24 February 1909.

2 Vancouver Traction Company, Distribution Record, 1909-1911, Puget Power Collection, Center for Pacific Northwest Studies, Western Washington University.

3 Independent, $2 \mathrm{July}$ and 24 December 1908.

Labbe, Fares, Please!, p. 110.

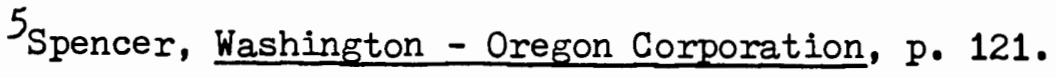

6 Ibid.

7 Independent, 15 October 1908.

8.Columbian, 19 April 1909.

9Milton, Bona, "Fiat Lux: Electricity in Clark County," Clark County History Annual, 20 (1979), pp. 23-24.

${ }^{10}$ See Columbian, 7 April 1909; and Independent, 15 April 1909.

${ }^{11}$ Ibid.

12 Columbian, 23 and 31 October 1908; and 19 February 1909.

${ }^{13}$ Independent, 21 April 1910.

${ }^{14}$ Columbian, 14 November 1908.

15 Ibid., 19 February and 12 March 1909.

16 Ibid., 17 March 1909.

${ }^{17}$ Independent, 25 March 1909. 
$18_{\text {Ibid. }}$

${ }^{19}$ Columbian, 18 and 22 June 1909.

20 Vancouver Suburban Railway, Articles of Incorporation, (Clarke County Auditor, 22 June 1909). The Vancouver Suburban Railway Company was not related to the Vancouver and Suburban Railway Company that was discussed in chapter iv.

${ }^{21}$ See Ibid.; Portland City Directory; and Vancouver City Directory, various dates.

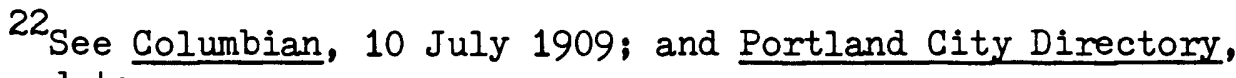
various dates.

23 Oregonian, 28 November 1947.

${ }^{24}$ Columbian, 10 July 1909.

${ }^{25}$ Clarke County Development Company, Articles of Incorporation, (Clarke County Auditor, 22 June 1909).

${ }^{26}$ See Columbian, 22 June 1909; and Portland City Directory, various dates.

27 Oregonian, 28 November 1947.

${ }^{28}$ Columbian, 22 June 1909.

${ }^{29}$ Vancouver Traction Company, Minutes of the Board of Directors' Meetings, 1908-1911, Puget Power Collection, Center for Pacific Northwest Studies, Western Washington University.

${ }^{30}$ Clarke County Auditor, Deeds and Mortgages, Book 79, p. 5; and Book 81, pp. 224-225.

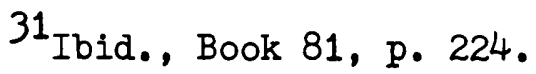

32 Ibid., p. 225.

33 Columbian, 13 August 1909.

34 Ibid., 29 June 1909. 
35 Clarke County Auditor, Deeds and Mortgages, Book 90 , pp. 324-344.

${ }^{36}$ Columbian, 4 and 5 August 1909.

37 Independent, 26 August 1909.

${ }^{38}$ Ibid., 24 March 1910.

39 Columbian, 13 May; and 13 and 30 June 1910.

${ }^{40}$ Public Service Commission of Washington, "The Public Service Commission of Washington ex rel C.H. Falk and Other Patrons, Complainant, vs North Coast Power Company, Respondent," 20 December 1918. (hereafter cited as Public Service Commission, "North Coast Power Company," 20 December 1918.

${ }^{41}$ Spencer, Washington - Oregon Corporation, p. 109.

42 Columbian, 14 and 28 June; 5 January; 9 July; and 29 October 1910.

${ }^{43}$ Ibid., $9 \mathrm{July}$ and; and 3 October 1910.

44 Ibid., 20 December 1910; 8 February 1911; and 19 December 1910.

${ }^{45}$ Independent, 7 July 1910.

${ }^{46}$ Columbian, 17 August; and 27 October 1910.

47 Ibid., 22 April 1910.

${ }^{48}$ Ibid., 30 July 1910.

${ }^{49}$ Vancouver City Directory, $1914-1915$.

${ }^{50}$ Clarke County Auditor, Deeds and Mortgages, Books $81-98$.

51 Independent, 2 July 1908.

52 Ibid., 20 May 1909 
${ }^{53}$ Ibid., 8 April 1909.

${ }^{54}$ See Ibid., 8 July 1910; and Columbian, 2 September 1909.

55 See Independent, 26 November 1908; and Columbian, 29 October; and 28 November 1910.

${ }^{56}$ Spencer, Washington - Oregon Corporation, p. 105.

${ }^{57}$ Ibid.

${ }^{58}$ Columbian, 21 December 1910.

59Vancouver Traction Company, Distribution Record, 1909-1911.

${ }^{60}$ Columbian, 16 December 1910; and 2 January 1911. 
CHAPTER VII

THE WASHINGTON - OREGON CORPORATION, 1911 - 1915

Isaac W. Anderson of Tacoma was the president of the Washington Oregon Corporation which was incorporated in December 1910, in Vancouver. ${ }^{1}$ Born in Philadelphia, Anderson had moved to Tacoma in 1877 to assist in constructing the Northern Pacific Railway. Eventually he became the manager of the Tacoma Land Company, a Northern Pacific subsidiary, and in the 1880 s and 1890 s was a member of the Tacoma city council. He became wealthy through his real estate dealings, and was involved with Tacoma schools, parks, lights, streets, and the Tacoma Hotel. Anderson had promoted the first street railway to Point Defiance Park in his adopted city. ${ }^{2}$

Other incorporators included some familiar names: Welch, and several of his employees, Edward Hall, Richard M. Boykin and Chiselette H. Berryman, all of Portland, and Seaman Deas Sinkler and Clyde A. Heller of Philadelphia who were elected vice-president and secretary-treasurer respectively. ${ }^{3}$ The connections between Philadelphia and the Pacific Northwest were through Anderson, most of whose family lived in Pennsylvania, and Welch, who had been the local agent for the Philadelphia firm, Rhodes, Sinkler and Butcher. ${ }^{4}$ The company was mortgaged to the Fidelity Trust Company of Pennsylvania for $\$ 5,000,000.5$

The Washington - Oregon Corporation was a holding company for a number of utilities in the two states. The Clarke County Railway Com- 
pany and the Vancouver Traction Company were acquired by it through the exchange of the new corporation's bonds for those of the Clarke County Development Company which controlled both of the companies. It also purchased the Vancouver Water Company and the Minnehaha Water Works. 6 The Washington - Oregon Corporation owned electric light companies in Chehalis, Kalama, Kelso and Tenino, Washington, and in Hillsboro and Rainier, Oregon. It owned water companies in Chehalis, Kelso, and Centralia, Washington, and in Hillsboro. The street railwa in Chehalis was also purchased by the corporation.?

Soon after the organization, some of the company's plans were revealed. Officials of the company claimed that they were going to build 100 miles of electric railway track in Clarke County (this had been placarded on the first cars to operate in 1908). To run these lines, more power would be needed so it was believed that the first extension would be north to the North Fork of the Lewis River where a power plant would be constructed. Other possible extensions that were mentioned included a line from Orchards, via Proebstel, to Camas, and one north from Proebstel to Brush Prairie and Hockinson. 8

The first extension to be built, however, was a short, though significant, one in Vancouver. The Vancouver Traction Company had purchased a freight car and some rolling stock in the fall of 1910 in order to increase its freight revenues. One problem was that the freight, whether cordwood or farm products, had to be loaded and unloaded by hand at the company's office on Main Street. Since the tracks were the same gauge as those of the Spokane, Portland and Seattle Railway, it was arranged to build a connection between them. This 
eliminated the need for loading and unloading the cars at the office as they could now be run between Orchards or Sifton and any point to which the railroad was connected. It was estimated that this would save up to $\$ 1.00$ per ton on transfer charges. In February 1912, the first freight passed over the spur tracks built on Ninth Street; eighteen tons of onions grown in Clarke County were shipped over the electric railway, onto the railroad tracks, and on to Stockton, California.' By 1913 the freight car was hauling six to eight carloads of cordwood per day, as well as produce, fertilizer and crushed rock, into Vancouver from Sifton, and was shipping a variety of goods back out into the county. The company grossed $\$ 10,503.46$ in freight earnings that year. 10

Although Vancouver had grown to the north, west, and northwest, the area directly east of the city had been slow to develop. This was due, in part, to the Vancouver Barracks which formed a barrier between the business district and Harney Hill. If a railway line could be built through the garrison on Fifth or Seventh Street, this access would open up the easter areas for development. Permission to build such a line, however, would have to be obtained from the War Department. The Washington - Oregon Corporation, believing the line would be profitable, accordingly requested permission. General Marion P. Maus, the garrison's commanding officer, supported the line, and Senator Wesley J. Jones in Washington D.C. worked towards its authorization. In the summer of 1912 the request was granted. ${ }^{11}$

The Washington - Oregon Corporation, however, never built the line. As one condition in granting permission to build, the War De- 
partment required the company to pave, and keep in repair, a roadway twenty-four feet in width. Manager Henry K. Lugger flatly stated that his company could not afford the $\$ 10,000$ such construction would cost, but would be willing to pave between the rails. Senators Miles Poindexter and Jones worked to get the permit modified and succeeded in 1914. ${ }^{12}$ But because of financial difficulties the Washington - Oregon Corporation was not able to build it.

The Clarke County Fair Association determined to take advantage of the interurban line shortly after it began operating. In the spring of 1911, ten acres were purchased on the Falk tract, east of Burnt Bridge Creek, and developed into a fairgrounds. The Washington - Oregon Corporation constructed a loop through the fairgrounds to facilitate the loading and unloading of passengers, and during the fair maintained a service from the ferry to the site every twenty minutes. ${ }^{13}$ The 1912 fair was quite successful for the railway but, according to railway manager George W. Ford, the 1913 one was lackluster and did not attract nearly as many people. He attributed this to the fact that the fair manager for this second year was a preacher who had "cut out everything he could of a sporting nature, which injured attendance to a great extent."14 Nevertheless fair week proved a profitable time for the railway.

Though the fair loop and connection with the Spokane, Portland and Seattle Railroad were useful and lucrative, they were not a part of the company's stated goal of 100 miles of line in the county. People living in the north part of the county, such as those in Ia Center and the Lewis River Valley, generally took a boat down the Iewis River to 
the Columbia River, just below Ridgefield, and then up the Columbia and Willamette to Portland to shop: this was easier than travelling to Vancouver. If an electric railway line was constructed out into this area, the farmers would be able to bring their produce into Vancouver and also shop there. This would be a benefit to the north county residents and the Vancouver businesses. Consequently there was a great deal of interest in extending the line out to those areas. ${ }^{15}$

Since construction of the lines was so expensive, it was suggested that the farmers assist in building them. County Commissioner William Lindsay of Manor (about seven miles northwest of Orchards) proposed that the farmers along the way donate $\$ 1.25$ per acre of their land 10cated within one-half mile of the track, and $\$ .75$ per acre located within the second half-mile. ${ }^{16}$ The company would need some assistance, just as it received when the line was built to Sifton.

In July 1912, a survey was completed between Sifton and Hockinson, a small community five miles northeast of Sifton. Representatives of the Washington - Oregon Corporation met in October with Commercial Club members and citixens of Hockinson. They explained that they were not looking for a bonus, but wanted to secure a right of way, and also suggested an investigation be made by the people of Hockinson to determine how much freight and how many passengers would be reached by the line. ${ }^{17}$ Apparently the building of the Sifton line had taught them that the funds to build were not the important consideration. Although business was increasing on the Sifton line, both freight and passenger, it was still not producing a profit in $1913 .{ }^{18}$

An estimate to build the 5.25 mile line to Hockinson from Sifton 
concluded that it would cost $\$ 15,000$ per mile for the track $(\$ 78,750)$, $\$ 2,637$ for the wire and poles, and $\$ 10,500$ for the substation that would be required at Hockinson. Another necessary expense would be $\$ 8,000$ for a new interurban car, making the total investment for the line to Hockinson approximately $\$ 100,000$. The estimated annual gross freight and passenger business that might be obtained from the sparsely populated farming community was $\$ 20,000$ which, concluded the author of the study, "would fall away short of paying the operating expenses and fixed charges on a $\$ 100,000.00$ investment." 19 The line to Hockinson was never constructed.

Though no extensions into the county were ever built by the Washington - Oregon Corporation, the company continually promoted the hope that it was considering such projects. At the beginning of 1913 Welch asserted that within the year construction would begin on an extension to Chehalis, which would eventually be continued through Centralia, Tenino, and Olympia to Tacoma. This was never started either. The implication that it was on the verge of extending its lines was probably useful to the company as it was experiencing competition from other franchise seekers. In August 1911, Lawrence Harmon, an attorney from Chicago, applied to the city for a franchise to run a street railway through the garrison to the east of town (he would also need the War Department's permission), and on some of the city streets on the West side. According to the Columbian, Harmon's interest in building these lines is what spurred the Washington - Oregon Corporation into investigating the building of a line through the garrison. 20

Harmon received a franchise for the city line in October 1911. 
He was to deposit a $\$ 1,000$ bond with the city by April 1, 1912 (to be refunded after $\$ 25,000$ had been spent on the line), and commence construction by April 1, 1913. He incorporated the Washington Trunk Railway with the stated goal of building a line north to Yakima and Ellensburg. It was thought that the line might connect at North Yakima with the Chicago, Milwaukee and Puget Sound line. 21

In December 1911, Harmon met with Clarke County farmers and tried to sell them $\$ 100$ shares of stock in his company. The first twentyfive dollars were due when the survey was completed, and the rest was to be paid as the line construction progressed. Harmon was "positive that at least 75 miles of rail would be laid the first year."22 In March, however, he appeared before the city council and requested an additional three months before he was required to comnence construction, claiming that the council's delay in granting him the franchise had put him behind schedule. His petition was unanimously defeated. Nothing more was heard of Harmon, and his franchise was revoked as the deadline for it to commence operation approached without any sign of work. 23

Several other companies expressed an interest in building a street railway in Vancouver. The Northwestern Electric Company applied for a franchise from the city in December 1912, for a railway, light and power system. The following April, Dr. Isabel Sedgwick Putnam of Vancouver applied for a franchise for a railway. In June the council defeated both of these applications. One reason for the denial was that the applicants were hesitant about bringing the matter to a final settlement, indicating to the council that they were not serious about 
building their proposed lines. Another concern was the financial strength of the companies. The Columbian contended that both the Washington Trunk Railway Company and the Washington - Oregon Corporation were under bonded. 24 It also pointed out in an editorial that

Electric lines are not built by erely obtaining franchises from Vancouver and telling around for months what is going to be done and harrassing the settlers for stock subscriptions, nor will the county be developed by wasting four years to build eight miles out into the county and speculate (sic) on the contiguous thereto and indulging in promises vague and indefinite. 25

Another reason that the Washington - Oregon Corporation did not build extensions was that funds that might have been used for construction were needed for repairs and maintenance due to the inferior original construction. In 1911 the company spent $\$ 54,892.82$ in improvements, of which over $\$ 20,000$ was for surfacing, track laying, and paving, and another $\$ 10,000$ for upgrading the power plant and substation equipment. The following two years the company spent $\$ 38,358.86$ on improvements. 26 From 1911 - 1913 the gross earnings averaged $\$ 63,640.74$ ( of which $\$ 9,235.08$ was from freight revenues, $\$ 256.76$ from advertising revenues, and $\$ 54,088.90$ from fares), against an average operating expense of $\$ 53,037.92$, including taxes (see figure 8 ).27 The annual net earnings averaged only $\$ 10,163.49$. Not counting depreciation of the track, equipment, and buildings, this amounted to less 2.5 percent profit on its investment. Clearly the Vancouver railway system was not a very profitable part of the Washington - Oregon Corporation and, consequently, the reluctance of the company to extend its line can be readily understood.

In the year ending June 30,1913 , the company's gross earnings 


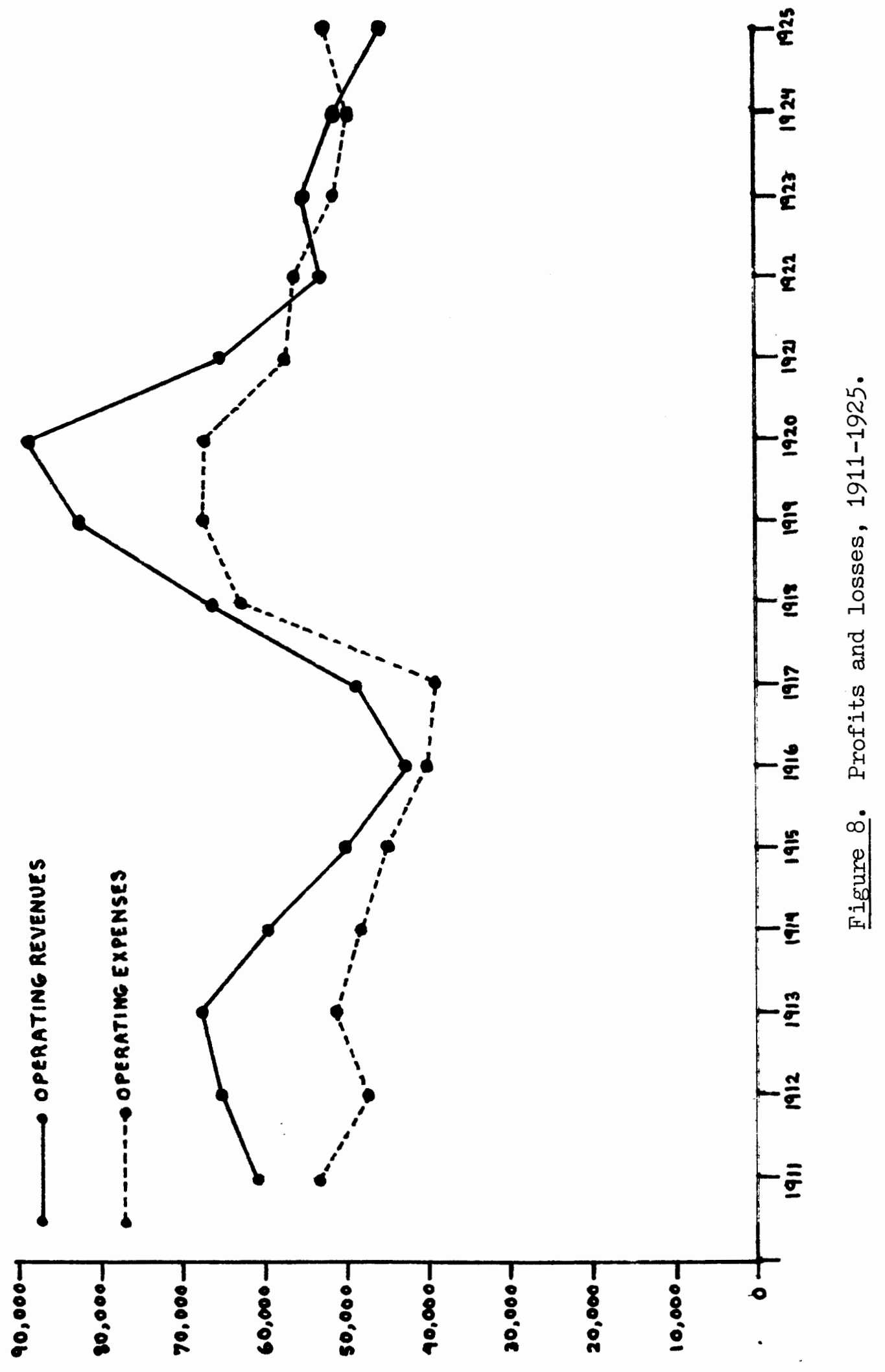


for its electric light departments (Chehalis, Kalama, Hillsboro, Kelso, Rainier, and Tenino) were about $\$ 147,000$ against operating expenses of about $\$ 100,000$. The water departments (Vancouver, Chehalis, Centralia, Hillsboro, Kelso and Tenino) grossed about $\$ 117,000$ against expenses of about $\$ 59,000$. Vancouver's water system earned about $\$ 50,000$ for the company by itself and its expenses were only $\$ 20,000$. The two electric railways owned by the Washington - Oregon Corporation (Vancouver and Chehalis) had gross earmings of $\$ 102,000$ against expenses of $\$ 72,000$ for a surplus of $\$ 30,000$. The total gross earnings (less $\$ 21,000$ in taxes) for the corporation exceeded the expenses by about $\$ 114,000 .^{28}$ The profits that the Washington - Oregon Corporation was generating were not sufficient to meet the expenses of maintenance, interest on the mortgage or improvements. President Anderson wrote a letter to the members of the Board of Directors in early 1913 expressing his concern about the company's financial condition, and requesting that the "Board take some action thereto."29 Wharton Sinkler of Philadelphia came out and reviewed the property. After much discussion a second mortgage was entered into with the Philadelphia Trust, Safe Deposit and Insurance Company in April. 30

The company's financial condition continued to decline in late 1913 and early 1914. At the January 17, 1914, Board of Directors' meeting it was decided that it was "inexpedient that any construction work be done at this time" and all currently under way was order halted, "except that work which is for the protection of the public or employees."31 On February 1, 1914, the company defaulted on its first mortgage by failing to pay the $\$ 400,000$ of interest that was due. ${ }^{32}$ 
In light of the corporation's difficulties, the Fidelity Trust Company, which held the first mortgage, declared the principal of the bonds due and payable in July. The Philadelphia Trust, Safe Deposit and Insurance Company did the same shortly thereafter. 33 In the face of these demands the Washington - Oregon Corporation admitted that its financial situation was bleak, and formally requested that a court appointed receiver take charge of the company. On the first of August, Elmer M. Hayden of Tacoma was appointed. 34

Hayden worked to reorganize the company. By the end of 1914 he was able to improve it substantially: the losses for the first seven months of the year (before it was in receivership) totalled $\$ 58,652.94$; for the last five months the loss was only $\$ 19,227.85$. The assets of the corporation were estimated at $\$ 4.5$ million. 35

In the fall of 1915 a group of Portland men, Chiselette H. Berryman, Richard M. Boykin, Benjamin F. Donahue, Herbert L. Harries, H.K. Lugger, Harry N. Putnam and L.W. Salisbury incorporated the WashingtonOregon Utilities Company. Most of the incorporators had been associated with the Washington - Oregon Corporation, which was to be sold soon, and they intended to place a bid on it. By the end of October they had succeeded in buying it and changed the name to the North Coast Power Company. The bond holders of the old company received general lien bonds for 40 percent of their claims, and preferred stock in the new company for the remaining 60 percent. Clarence M. Brown of Phildelphia became the president of the North Coast Power Company which was financed by two Philadelphia firms, the Commercial Trust Company and the Germantown Trust Company. It was mortgaged to these firms for a total 
exceeding $\$ 1$ million. 36 
NOTES FOR CHAPTER VII

$1_{\text {Washington - Oregon Corporation, Minutes of the Board of Direct- }}$ ors' Meetings, 1911-1915, Puget Sound Power and Light Collection, University of Washington., 27 December 1910.

2 Tacoma News Tribune, 3 January 1927; and 2 January 1977. 1910. Washington - Oregon Corporation, Minutes of Board, 27 December

${ }^{4}$ Labbe, Fares, Please!, p. 122.

Washington - Oregon Corporation, Minutes of Board, 1 April 1911.

6 Ibid., 9 March 1911.

${ }^{7}$ Columbian, 5 December 1913.

$8_{\text {Ibid., } 16 \text { December } 1910 .}$

9 Ibid., 23 September 1910; 14 March; 28 February; and 2 March 1912.

${ }^{10}$ Spencer, Washington - Oregon Corporation, p. 109.

${ }^{11}$ Columbian, 11 September 1911; 7 June; and 15 July 1912.

12 Ibid., 16 January 1913; 8 January; and 3 February 1914.

13 Ibid., 6 April 1911; 2 August; and 10 September 1912.

${ }^{14}$ Spencer, Washington - Oregon Corporation, p. 112.

${ }^{15}$ Columbian, 24 January 1912.

${ }^{16}$ Ibid., 23 January 1912.

17 Ibid., $16 \mathrm{July}$; and 13 October 1912. 
${ }^{18}$ Spencer, Washington - Oregon Corporation, pp. 118-119.

${ }^{19}$ Ibid. , p. 118.

${ }^{20}$ Columbian, 25 January 1913; 8 and 23 August 1911.

${ }^{21}$ Ibid., 17 and 30 October 1911.

$22_{\text {Ibid., }} 28$ December 1911.

23 Ibid., 19 March 1912; and 19 March 1913.

24 Ibid., 17 December 1912; 8 April and 3 June 1913; and 14 November 1911.

25 Ibid., 30 January 1912.

26 North Coast Power Company, Financial and Statistic Report, 1916 -1920, Puget Sound Power and Light Collection, University of Washington.

${ }^{27}$ Spencer, Washington - Oregon Corporation, p. 110.

${ }^{28}$ Columbian, 5 December 1913.

29 Washington - Oregon Corporation, Minutes of Board, 18 February 1913.

30 Ibid., 15 April 1913; and 17 February 1914.

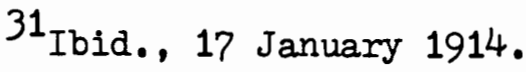

32 Ibid., 21 July 1914.

33 Ibid., 10 August 1910.

34 Columbian, 1 August 1914.

35 Ibid., 25 February 1915.

${ }^{36}$ Ibid., 15 and 28 October; 1 November 1915; 20 March 1916. 
CHAPTER VIII

THE NORTH COAST POWER COMPANY, 1915 - 1923

The interurban and street railway industry in the United States began a slow decline in the period immediately preceding World War I. This decline accelerated through the war despite the good record of many lines during this time. ${ }^{1}$ In Vancouver local as well as national factors would have a major impact on the city and county. Ultimately these led to the cessation of service of the street railway and interurban lines.

Other forms of transportation were providing increasing competition. As early as 1910 the city was licensing the automobile cabs that were becoming prevalent on its streets. ${ }^{2}$ In October of that year, John P. Lundberg advertised that he had

placed his automobile in the passenger service to meet the Vancouver ferry and all trains arriving at the union railway station of this city. The rate charged within the city is $25 \%$. will answer all calls. 3

One year later the Pioneer Auto Truck and Merchants Delivery Company began operating between Vancouver and Portland. Its arrival was hailed as a "milestone in Vancouver" as it replaced the "dinky freight car" of the Portland Railway Light and Power Company. 4 The new company's main advantage was that it eliminated the double, and sometimes triple, handling of the freight, as it did not need to unload for the ferry and could drive directly to the freight's destination. Within two years the company was running four trucks per day, and virtually 
all of the freight between Vancouver and Portland was being carried this way. 5 During the war the trucking industry grew rapidly in the United States. There was a shortage of railroad cars, particularly on the West Coast, which necessitated that another means of freight transportation be developed. 6

To serve the outlying communities, several auto stage companies were formed. They used large automobiles and kept regular schedules and routes. In the fall of 1913 one could take an auto stage from Vancouver to La Center, Brush Prairie, Camas or Manor. Within six months, Orchards, Battle Ground, Meadow Glade, Ridgefield, Felida, and Sara could be reached this way. The stage to Manor ran the thirty mile round trip twice daily. It took about one hour each way and the fare (one-way) was fifty cents.?

Besides the auto cabs, auto stages, and the fledling trucking business, another development in transportation that provided direct competition with the street railway was the jitney. Jitneys were large automobiles, often with custom bodies, designed to carry many passengers. They would follow the street car routes, pick up people waiting for a ride, and would only charge five cents ("jitney" is a slang term for a nickel), the same as the street cars. The jitneys did not need to keep regular schedules and routes and could thereby avoid the less profitable times and routes that the street railways were required to abide by their franchises. And, since they did not need to maintain an expensive track but could run on the public roads without charge, they were quite profitable to the drivers. Jitneys also provided an opportunity to enjoy an automobile ride; sometimes they were referred 
to as the "poor man's automobile."8 By 1916 pneumatic tires were beginning to be used which, when combined with the increasingly common paved roads, provided a very comfortable ride. 9 The novelty, fun, and excitement of an automobile ride had captured the imagination of the public; it is not surprising that people would choose a jitney over a street car.

A Vancouver firm, the Interstate Passenger Service Company, was formed in September 1914, to meet the Vancouver ferry as it landed on the Oregon side of the Columbia River. It would then take the passengers into Portland for the same fare that the Portland Railway Light and Power Company charged. The street car company built several gates to prevent the jitneys from backing up right next to the ferry, and constructed a covered walkway to facilitate the passengers boarding its cars directly from the ferry. In early 1915 the Interstate Passenger Service Company establinsed jitney service in Vancouver between the ferry and various downtown points, and to East Vancouver, which did not have a street car line. 10

In spite of the apparent success of the jitneys, there was a great deal of dissatisfaction with them. Since they were uninsured, it was claimed that they were unsafe, and they added congestion to the streets. The street car companies complained that in using the the public roads for free, the jitneys had an unfair advantage, and warned that if they were allowed to continue, the result would be thousands of unemployed motormen. The president of the Portland Railway Light and Power Company, Franklin T. Griffith, railed against the jitneys claimIng that they were "sapping the life-blood of street car and taxicab 
companies."11

The Washington State Legislature responded to this protest in 1915 by passing a law requiring the jitney drivers to post a $\$ 2,500$ surety bond. 12 This, along with the high cost of upkeep to the vehicles and strict enforcement of the regulations concerning the limited areas where they were allowed to pick up passengers, helped stem the threat that jitneys posed to the street railways. ${ }^{13}$ The jitneys did give the people a taste of the advantages of an automobile, and foreshadowed the competition that such vehicles would bring.

Privately-owned automobiles were becoming more common in Vancouver, too. The first one owned by a city resident was purchased in 1906, but when the Ford Model $T$ began to be produced at a cost of less than $\$ 600$ each in 1911 , automobiles were priced so that people of average means could afford one. ${ }^{14}$ By the fall of 1915 over 600 cars had been licensed in the county. Within ten months another 300 had been added for an average of one automobile for every twenty-nine people in Clarke County. 15

The advantage that street cars had by travelling on rails, as opposed to automobiles that had to travel on rough roads, was gradually eliminated in the prewar period as more and more streets were paved. In 1910 a survey was made for the Pacific Highway that was to connect Mexico and Canada; three years later construction commenced. The section through Vancouver and Clarke County was completed in 1922. Fourth Plain Road between Vancouver and Orchards was given an oiled macadam surface in 1912, and five years later a bitulithic pavement was laid. To connect the communities east of the city, it was decided in 1917 to 
build the Evergreen Highway. By 1921 Vancouver had 22.3 miles of paved roads and the county had 61.7 .16

The impact of these alternate methods of transportation on the street railway system can readily be seen by examining the records of the North Coast Power Company and its predecessor, the Washington Oregon Corporation. In 1914 the system (both city and interurban lines) carried 902,497 passengers (see figure 9). The next year, in which there was much jitney activity, automobile stages had been well established, and a number of automobiles were in use, the number of passengers dropped 18 percent to 737,014 . In 1916 it dropped by 13 percent to 638,377 . The system lost over 30 percent of its ridership in two years, and there were no apparent means to reverse this trend. ${ }^{17}$ An examination of the operating revenues and expenses during these years is indicative, too, of the problems that the system was facing. In 1914 the operating revenues were $\$ 59,704.78$ against operating expenses of $\$ 47,748.63$ for a gross income of $\$ 11,920.15$. As the ridership declined in the next two years, both revenues and expenses dropped, though the former did so much quicker than the latter. The gross income for 1915 was $\$ 5,553.98$ and for 1916 a loss of $\$ 350.38$. The company's losses were increasing annually. ${ }^{18}$

In the early years of the twentieth century, there was little industry in Vancouver and Clarke County. The county ranked thirteenth in Washington in the value of its industrial products in 1900. In the prewar years several steps were taken that ultimately permitted Vancouver to participate in the wartime boom economy. By 1920 the county had risen to sixth in the state by value of its industrial products. ${ }^{19}$ 


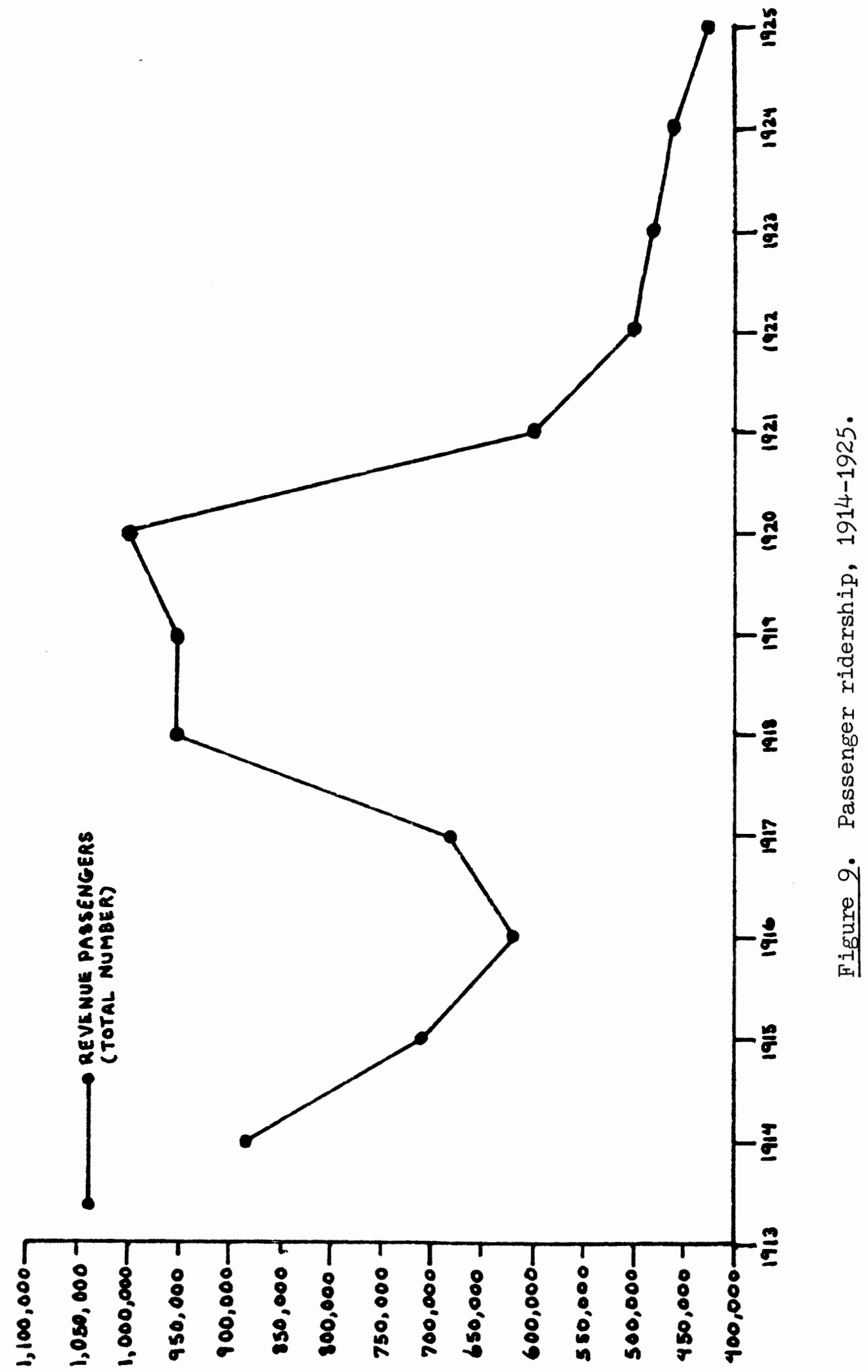


There was a growing awareness of a definite need for an interstate bridge. The ferry crossing the Columbia River, operated by the Portland Railway Light and Power Company was steadily increasing its business. In 1915 it averaged over 300 vehicles per day and this figure increased by 6 percent the next year. On one summer Sunday over 700 vehicles were ferried across, a crowd which created a long line and prolonged delay. 20

The Vancouver Commercial Club and the Portland Chamber of Commerce had raised $\$ 5,000$ in 1912 for a survey to determine the estimated cost of the bridge, and then sought financing from their state legislatures. The Oregon State Legislature united with Multnomah County and devised a plan for their portion of the cost, but the Washington State Legislature's appropriation was vetoed by the governor. In June 1913 a special election was held in Clarke County in which the citizens voted overwhelmingly $(5,393$ to 804$)$ to bond the county to its limit for the bridge. On February 27, 1915, the contract was awarded; construction commenced that afternoon. 21

It had been alleged that the proposed interurban line to Hockinson had been delayed because of the lack of access to Portland. After the community had raised the bonus that the street railway company requested, an official of the Washington - Oregon Corporation went to Philadelphia to make arrangements with a bonding company. He was told that all of the money he wanted was available, but that first the street railway must get its line into Portland. Farmers, believing that the bridge would bring them railway extensions and access to the Portland markets, readily supported the bonding for the bridge. In 
March 1914, the Washington - Oregon Corporation filed a petition with the bridge commission for a franchise to use the bridge. 22

Once again, however, there was a problem with the gauge of the tracks. Those of the Portland Railway Light and Power Company were narrow, and the Vancouver line had standard gauge tracks. Both companies could use the bridge, as it was being built with a common user clause, but once on the other side would not be able to use the other line's tracks. The line from Portland needed only to build a short section once it crossed the bridge and it would have a connection between the two cities; the Vancouver line would have had to secure a right of way and build tracks clear into downtown Portland for its connection. Consequently the Vancouver line did not pursue using the bridge, much to the dismay of the farmers.

On Valentine's Day, 1917, the "City of Vancouver," last of the series of ferries which had carried passengers and vehicles across the Columbia River for sixty-nine years, ceased running and the Interstate Bridge was officially opened. The Portland Railway Light and Power Company's street cars came across the bridge and made a loop up Washington Street to First, east one block to Main, north to Third, west to Washington and south back to the bridge. Vancouver citizens could now catch a street car every thirty minutes for Portland for thirty cents round trip, of which seven cents (three and one-half each way) was for the bridge toll. The street car fare (including the ferry fare) had been twenty-five cents per round trip the past two years, having been lowered from thirty cents to meet the jitney competition. The toll for the automobiles to use the bridge was five cents per passenger each 
way. 23

Another major change during these years was the improvement of the harbor. Since 1892 various attempts had been made by the Army Corps of Engineers to prevent the Columbia River from flowing around the south side of Hayden Island into the Oregon Slough. Through the use of dikes and revetments, the corps hoped to divert the current along the north side of the island, in front of Vancouver, and thereby scour out a deeper channel. However, either the spring freshets would wash away these structures, or insufficient current would be diverted, and the channel remained too shallow. 24 The corps also occasionally dredged the river. At the turn of the century a twenty-six foot deep channel was virtually a requirement on the river; ${ }^{25}$ Vancouver's controlling depth was as shallow as nine feet during the low water periods. 26

With the fine harbor at nearby Portland, where the corps had been actively working since 1866, it was hard to justify large expenditures (over $\$ 150,000$ by 1913) with such poor results. ${ }^{27}$ In 1910 an engineer for the corps reported that he did "not believe that the commercial interests involved are sufficient to justify the United States in paying even one-half the cost of maintenance" of the Vancouver Harbor. 28 Indeed, since Vancouver's principal exporter, the Pittock and Leadbetter Mill had burned down in June 1908, there had been even less need for a deeper channel. 29

By 1910 the maritime industry of the Pacific Northwest had come through a period of unprecedented development, aided by the Klondike Gold Rush, the Russo - Japanese War, and the rebuilding of San Francis- 
co after its devastating earthquake. ${ }^{30}$. The Columbia River had been substantially improved as a water route. Upriver from Vancouver the Cascade Locks had been completed in 1896 and the Celilo Canal was slated to be finished in $1915 .^{31}$ Through the construction of jetties at the mouth of the river, the entrance had been widened and deepened. What was even more promising to the Pacific Northwest maritime industry was the Panama Canal. Construction on it was proceeding steadily, and when it opened (1914) it would cut the distance a ship would have to travel between the two coasts by 8,000 miles. 32

To assist the harbor towns in the promotion of their facilities, the Washington State Legislature passed a law in 1911 which enabled communities to set up port districts. A port commission is established by election, and through taxation of property in its district improves its harbors, docks, and warehouse facilities. 33 Following Seattle's lead, Vancouver established a port district in 1912.34 Arrangements were then made with the Army Corps of Engineers to share in the cost of improving and maintaining the deeper channel.

In 1914 the Port Commission spent $\$ 15,000$ building dikes and revetments. With a dredge rented from the corps it had a channel 150 feet wide by 20 feet deep cut through the shoal in 1915 for $\$ 7,500$. By 1917 the harbor was twenty-four feet deep for six months of the year, and only as shallow as seventeen or eighteen the rest of the time. 35 This was a substantial improvement.

The deepening of the channel was an aid in the industrialization of Vancouver during the First World War. Soon after the United States entered the war in April 1917, it was announced that the Columbia Riv- 
er Shipbuilding Company would be constructing wooden ships at a site just below the Interstate Bridge. This yard was the Standifer yard, named for one of its backers, Guy Standifer. Construction began in April and it was formally dedicated in August 1917. Further downriver the Motorship Construction Company leased a site from the Pittock and Leadbetter Lumber Company, in May, to build smaller wooden ships. Vancouver citizens voted overwhelmingly $(2,825$ to 39$)$ in January 1918 to bond themselves for $\$ 185,000$ to purchase and improve a fifty-four acre site west of the railroad bridge. It was then leased to Standifer who constructed a yard there to build steel ships. The Standifer steel yard employed 3,500 to 4,000 employees, the wooden yard about 450 workers, and the Motorship Construction Company employed 65.36

Military activity in Vancouver greatly increased in the war years. During the first years of the century, the post had almost been deserted. Visiting in the summer of 1913, Secretary of War Lindley M. Garrison and Major General Leonard Wood inspected it and reassured the citizens that the Vancouver Barracks would not be abandoned, but would definitely be retained and likely enlarged. Towards the end of 1916, during the Mexican Border Conflict, more troops were sent to Vancouver, and by the end of the year, there were about 450 soldiers stationed there. As the United States entered the war, the number grew quickly. In May 1917, it was reported that accomodations must be made for 5,000 or 6,000 men, and that work was to commence immediatley on 250 buildings. 37

Besides the regular troops, in late 1917 a special division of the Signal Corps was created to insure that there would be an adequate 
supply of spruce for airplane construction. The headquarters of the Spruce Production Division were located in Vancouver where a large mill was constructed to cut the spruce to the precise dimensions required. It operated around the clock and employed 400 to 500 men. 38

The unprecedented activity in Vancouver brought boom times. There had been a slump in growth throughout the Pacific Northwest from 1910 to 1916 which the wartime activity ended; the area then grew rapidly, faster than the nation as a whole. In the decade, 1910-1920, Vancouver's population increased 35 percent from 9,300 to $12,637.39$ The corresponding figures for Clarke County, including Vancouver, were 26 percent, from 26,115 to $32,805.40$

The wartime economy and boom had a substantial impact upon the Vancouver street railway. In 1917 the ridership of the system (both city and interurban lines) increased 10 percent to about 700,000. The following year it grew by one-quarter million ( 36 percent) to about 950,000, a figure it maintained through 1919. In 1920 the line reached its apogee with 1,017,331 passenger rides. This was an increase of 60 percent over the prewar low of 640,000 , registered in 1916.41

Although the increased ridership brought in more fare revenues, it also caused problems for the street railway company. Many of the new riders were shipyard workers, so the transportation that they required was concentrated at specific times. Consequently, the company had to provide extra cars during these peak periods. The cars began running from Sifton at 5:10 AM, and the last one left the shipyards at 11:20 PM; previously the last one had been at 10:00 PM. In spite of these efforts to modify the schedule and the addition of trailer cars, 
there were still complaints concerning the crowded conditions, and that the company was not maintaining its schedule. 42

Another problem the company faced during the war years was the increased cost of labor. Not only did it have to pay its men more, it also had trouble retaining the employees since better jobs were available at the shipyards. Between 1917 and 1918 the average wage for the Vancouver street railway workers rose from 28-30 cents per hour to $40-45$ cents per hour. 43

To save money on labor costs the North Coast Power Company had instituted one-man service in March 1916, when its ridership was in decline. Instead of a motorman and a conductor, the cars only had a motorman who would collect the fares, as well as run the car. This cut labor costs in half for the operation of the cars, though it did slow the loading and unloading of passengers as they all had to use one end of the car. The depot car line, which had been averaging $\$ 3.00$ per day in fares against $\$ 6.00$ per day for the wages for the two men running it, was the first to be changed. The company was pleased with the results and several months later changed the Capitol Hill and Sifton routes too. By the fall of 1918, however, the cars had too much business to operate efficiently under the one-man system, and they all went back to the two-person operation with the exception of the two smallest cars. 44

One way that the company surmounted the labor shortage was by hiring women. In June 1918, it was announced that all of the employees at the car barns, with the exception of the blacksmith, were now females. The jobs of mechanic and maintenance "man" were taken by fe- 
males, as the men had gone "to take up some line of war work." 45

The most serious accident in the history of the Vancouver street railway occurred at this time while Caroline Reinohl was being trained as a "motorman." Motorman Franklin P. Seals was at the rear of the Sifton car with Reinohl at the controls. Seals had temporarily left the front to collect fares when the freight car, running off schedule, suddenly appeared, bearing down upon them. He rushed forward, arrived at the time of collision, and was thrown from the car. Seals died from his injuries; Reinohl sustained a broken and crushed leg, and several of the passengers were injured. 46

By comparing operating revenues with operating expenses for the years 1916, 1917 and 1918, the result of the increase in ridership and the rise of operating expenses can be observed. In 1916 the operating expenses exceeded the operating revenues or $\$ 41,540.28$ for a net operating income loss of $\$ 350.58 .47$ By 1917 the operating revenues had increased by almost $\$ 6,000$ and the expenses had dropped $\$ 700$, netting the company a gross income of $\$ 6,180.84$. The next year operating revenues increased by over $\$ 18,500$ to $\$ 65,575.18$, but the operating expenses had increased by almost $\$ 24,000.48$

In light of the quickly rising costs of operation and the losses that the North Coast Power Company was sustaining, the citizens of Vancouver were probably not surprised to learn that the company had applied to the Washington State Public Service Commission for a fare increase in August 1918. The company asked for a ten cent raise to ride from the ferry to Sifton, one-way, which would make it twenty-five cents. It had been fifteen cents since the inception of service. By 
state law the fare in the city limits was set at five cents, so the interurban portion of the system would have to bear the increase. It did not seem equitable that the fare was five cents for the 3.35 miles from the ferry to the city limits and then another twenty cents for the additional 5.52 miles to Sifton. Those who lived just outside of the city limits were the most vociferous in their complaints; they did not believe that they should have to make up the deficit for the whole system. 49

Sveral citizens, including Mayor Grover R. Percival, filed a formal protest against the fare increase and the Public Service Commission held a hearing on October 30. Both company representatives and the protesters were present. North Coast Power Company General Manager Richard M. Boykin testified that the increase in expenses, which necessitated the fare increase, was due to the rising costs of labor and materials. The track foreman's wages, for example, had gone up from $\$ 75$ per month to $\$ 107.39$. Track shoes had been 2.9 cents per pound, now were 5.5 cents per pound. Ties which had sold for $20-25$ cents apiece, were now 42 cents each, and rails, which had been $\$ 39$ per ton when the line was constructed, were now $\$ 77$. In 1917 operating costs per car mile were 15.9 cents; in the first nine months of 1918 they averaged 24.4 cents. 50

The citizen's complaints concerned the lack of punctuality of the cars and the inequality of the fares between the city and interurban portions of the line. Mayor Percival pointed out that the company was making a substantial profit on another franchise it held with the city for the municipal water system, but the commission could not take this 
into account when considering whether or not an increase in the fare was justified. 51

Based upon the company's figures, it was obvious that the street railway system was losing money. The Public Service Commission concluded that the system could not continue to operate at the old rate "without embarrassment to the company" and permitted the increase in the fare to take place in mid-November. 52 The year ended with the system earning total revenues of $\$ 65,575.18$ against operating expenses of $\$ 64,111.33$ for a gross income of $\$ 1,463.85 .53$

Street railways in Washington cities were finding it difficult to meet their expenses with a five cent fare. The Washington State Legislature amended the law limiting the fare in February 1919, and provided means by which a railway could increase its city fare. ${ }^{54}$ In March the North Coast Power Company applied for a seven cent fare for the city portion of its system. The Vancouver Commercial Club filed a protest and the Public Service Commission held a hearing on April 21st. 55 It was determined that the value of the system was approximately $\$ 464,000$, and, if the fare increase was granted and the ridership held, the system would earn .67 percent on its investement. The increase was permitted and went into effect immediately. The Public Service Commission did note in its report that "some of the lines ... are in bad condition and in the interest of all concerned they should be in better operating condition. "56

At the same time that the company was applying for a rate increase on the fall of 1918, ridership was diminishing because of the national influenza epidemic. To prevent the spread of the disease, all 
activities in institutions such as schools, lodge meetings and theatres, were forbidden. People were warned to avoid crowds. 57 The Washington State Board of Health issued an order requiring gauze masks to be worn in a number of places, including "all street cars and busses."58 The crews of the street cars were to keep them well ventilated; many of the lines put their summer open cars into service. Because of the decline in ridership, the North Coast Power Company pared back its service to Sifton until the epidemic eased after Armistice Day. 59 A long-term effect of the influenza epidemic was the belief that a street car, like other poorly ventilated, crowded, places did not have healthy environments. An automobile, it was noted, was able to surmount these detrimental aspects of the street railways.

Although the war ended in November 1918, the shipbuilding industry continued until early 1921. In fact at the war's end, none of the ten steel ships that had been contracted for had been constructed; the first one was launched on December $31,1918.60$

The street railway ridership in 1919, about 950,000 persons, was the same as in 1918. The next year it reached its high point with $1,017,331$ passengers. ${ }^{61}$ Part of this increase can be attributed to a gasoline shortage that the area experienced in the early summer of 1920. Some of the 2,000 workers that came to the shipyards in automobiles (from Vancouver and Portland) had to switch to street cars. A county commissioner revealed the changing attitudes and expectations that people had concerning transportation when he suggested that tents be erected near the shipyards to house those who normally came in automobiles, because he believed "that the street car ride will prove too 
long for many who are accustomed to a more rapid transit."62

The United States experienced a postwar recession commencing in late 1920 and continuing into $1921 .^{63}$ Although it was not prolonged, its effect was sharp. As a result of the recession and the closing of the shipyards, the Vancouver street railway and interurban experienced an abrupt drop in ridership. From 1920 to 1921 it went from over $1,000,000$ to 600,000 , a loss of 41 percent. This was the lowest ridership the company had experienced since 1916. From 1916 to 1922 it dropped another 18.4 percent down to 490,000. In 1923 there were 480,000 passengers. 64

The decline in ridership was reflected in the operating revenues. In 1919 the system had total operating revenues of $\$ 83,494.11$ against operating expenses of $\$ 67,043.83$ for a net revenue of $\$ 16,450.28$. The next year the revenues increased by about $\$ 5,000$ and the operating expenses stayed the same for a net revenue of $\$ 21,800.44$. With the sharp decline in ridership in 1921, revenues decreased $27 \%$ to $\$ 64,722.54$, and operating expenses decreased $15.7 \%$ to $\$ 56,392.00$ for a net revenue of $\$ 8,330.54$. By 1922 the operating expenses exceeded the revenues for a net revenue loss of $\$ 832.53$. The financial condition of the railway was deteriorating rapidly. 65

Besides declining ridership, another problem that the company faced during these years was the expense of paving. According to its franchise with the city of Vancouver, the company was required to pave between and on each side of the rails if the street was paved. The tracks were deteriorating to the point where major overhauls were needed, yet the company could not afford to do it. This was a source of 
conflict between the city council and company officials. In July 1919, the city decided to pave Twenty-second Street on which the street railway had tracks. Rather than spend the money to have it paved, the North Coast Power Company elected to remove its track from that street and re-route the cars that had been using it onto Twenty-sixth Street. 66

At a city council meeting in early 1920, several councilmen expressed their dissatisfaction with the company's maintenance of the streets. Councilman Charles W. Davis asked if it was possible to force the street railway company to make the repairs. Councilman John B. Atkinson agreed that something needed to be done and "favored making the company come to time or revoking the franchise."67 Coming to the defense of the company, Councilman Willard M. Salsbury claimed that it had not made enough to pay its taxes or interest out of its earnings for the past nine years, and recommended allowing it to continue, making such repairs as were possible. In the ensuing discussion it was discovered that the majority of the council members were against the company, but they cooled down and decided to delay taking any action against it. The Columbian remarked, "Just how near Vancouver came to losing its only street car system will probably never be known. However things came almost to a point where action looked certain." 68

In August 1920, the dispute about paving was raised once more at the city council, this time concerning Columbia Street. The North Coast Power Company declared that the cost of paving the street under the city plan $(\$ 5,000)$ was too much for them, and offered two alternative plans. By the first one, the company would spend $\$ 2,300$, all that 
it said it could afford, and the city and property owners were to make up the difference. Or with the second option, the street railway company would pay the $\$ 5,000$ over an extended period of time, provided that the city council would change the franchise so that the company would not be obligated in the future to pay for the paving between its tracks. Atkinson attacked this offer and "pointed out that changing the franchise might mean a cost of thousands of dollars to property owners in the future, while the company would save this and get off by paying the difference between $\$ 2300$ now and $\$ 5000$ or $\$ 2700 . " 69$ The car company also came in for some considerable "ragging" from some of the other council members. Davis stated that he was "willing to support a street car company, but preferred to support the real thing."70 He declared that the North Coast Power Company was "No Good," and seriously doubted whether it would be advisable to keep it in the city. Mayor Percival appointed a special committee and referred the matter to it. ${ }^{71}$ Three weeks later, North Coast Power Company spokesman, A.L. Clarke, said that if the council insisted upon its original demands, that the company would be forced to "pull" its tracks and discontinue service on Columbia Street. ${ }^{72}$ The dispute between the company and city ended on September 20th with the intervention of the Columbia Dairy Products Company, located just off Columbia on Sixth Street. It announced that it would pay one-thind of the cost of the paving if the street railway company and city would split the remaining amount. 73 With their assent the street was paved and the street cars continued to run on Columbia.

In an effort to cut expenses, the company laid off six men and 
went to one-man operation on all of its cars in August 1919. Fourteen months later it seriously considered increasing its city fare from seven to ten cents. Although the Public Service Commission apparently granted the company permission to do so, the increase was not implemented until 1924.74 Perhaps the officials of the North Coast Power Company believed that the three cent increase would cause Vancouver citizens to seek alternative ways of transportation, such as automobiles or buses. This decline might be large enough to offset the revenues from the fare increase.

The North Coast Power Company had tried to cut its expenses. In consideration of the mounting costs of maintenance and steadily declining ridership, the street railway faced a doubtful future. The owners were not the ones destined to see its demise, however. On January 18 , 1923, it was announced that the entire holdings of the North Coast Power Company in Southwestern Washington and Northwestern Oregon had been purchased by Puget Sound Power and Light Company of Seattle through its parent firm, the Stone and Webster Corporation of Boston. 75 
NOTES FOR CHAPTER VIII

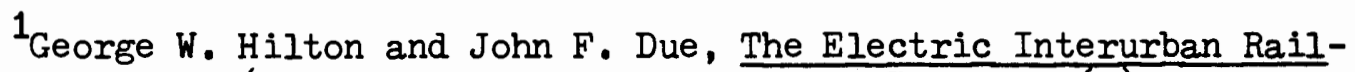
ways in America, (Stanford: Stanford University Press, 1960), p. 209.

20olumbian, 18 october 1910.

3 Ibid., 14 October 1910.

${ }^{4}$ Ibid., 2 November 1911.

5 Ibid., 17 September 1913.

$6_{\text {Ellis }}$ L. Armstrong, Suellen M. Hoy, and Michael C. Robinson, eds., History of Public Works in the United States, 1776-1976, (Chicago: American Public Works Association, 1976), p. 79.

7 Columbian, 20 September 1913; and 24 March 1914.

8 Blaine A. Brownell, "The Notorious Jitney and the Urban Transportation Crisis in Birmingham in the 1920s," Alabama Review 25 (April 1972), p. 114.

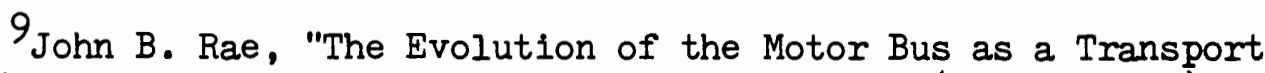
Mode," High Speed Ground Transportation Journal 5 (Summer 1971), p. 223.

${ }^{10}$ Columbian, 22 September; 3 December 1914; and 5 February 1915.

${ }^{11}$ Ibid., 9 February 1915.

12 Oregonian, 31 October 1915.

13 Columbian, 21 April 1915.

14 See Ibid., 29 May 1928; and Armstrong, Hoy, and Robinson, History of Public Works, p. 73.

15 Columbian, 25 September 1915; and $10 \mathrm{July} 1916$. 
16 Ibid., 22 May 1913; 29 May 1928; 11 September 1922; 6 April 1912; 8 November 1917; $20 \mathrm{July} \mathrm{1917;} \mathrm{and} 29 \mathrm{July} 1921$. 1916-1920.

${ }^{17}$ North Coast Power Company, Financial and Statistic Report,

${ }^{18}$ Ibid.

${ }^{19}$ See Lancaster Pollard, A History of the State of Washington, 4 vols. (New York: The American Historical Society, 1937), 2:208; and Ted Van Arsdol, "World War One Brought Boom Times," Clark County History Annual 17 (1976), p. 53.

20 Columbian, 13 February 1917; and 7 August 1916.

21 Don DuBois, "DuBois and Sons," Clark County History Annual 24 (1983), p. 50 .

22 Columbian, 25 June 1913; 27 and 6 March 1914.

23 Ibid., 22 June 1915; 3 and 16 February 1917.

24 Henry Richmond, III, The History of the Portland District Corps of Engineers, 1871-1969, (U.S. Corps of Engineers, 1970), pp. 143-144.

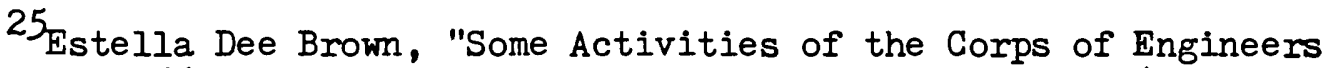
in Oregon, 1866-1890," Reed College Bulletin vol 31., no. 5 (August 1953), p. 36.

26 U.S. Army Corps of Engineers, Report of the Chief of Engineers, U.S. Army, 1914 , p. 1514.

27 Ibid., p. 1515 .

${ }^{28}$ U.S. Army Corps of Engineers, Report of the Chief of Engineers, U.S. Army, 1910, p. 948.

${ }^{29}$ Columbian, 11 June 1908.

${ }^{30}$ Gordon Newell, ed., The H.W. McCurdy Marine History of the Pacific Northwest, (Seattle: Superior Publishing Co., 1966), p. 144. 
${ }^{31}$ See Ibid., p. 3; and Columbian, 5 May 1915.

${ }^{32}$ Pollard, A History of the State of Washington, $2: 172$.

33 James H. Hitchman, The Port of Bellingham, 1920-1970, Occasional Paper no. 1., (Bellingham: Center for Pacific Northwest Studies, Western Washington State College, 1972), p. 7 .

${ }^{34}$ Columbian, 8 April 1912.

35U.S. Army Corps of Engineers, Report of the Chief of Engineers, U.S. Army, 1917, p. 1722 .

36 Van Arsdol, "World War One," pp. 64-65 and 70.

37 Ibid., p. 56.

${ }^{38}$ Ibid., pp. 55-56 and 68-69.

39 Tattersall, "The Economic Development of the Pacific Northwest to $1920, "$ p. 100.

${ }^{40}$ Robinson, Washington State Statistical Abstract, pp. 16-17.

${ }^{41}$ Clarke County Development Company, Petition: In the Matter of the Abandonment of Street Railway by the Clarke County Development Company, Puget Sound Power and Light Collection, University of Washington, 1926 , p. 4. (hereafter cited as Clarke County Development Company, Petition for Abandonment).

42 Columbian, 25 February; and 18 July 1918.

${ }^{43}$ Public Service Commission, "North Coast Power Company," 20 December 1918.

44 Columbian, 8 March; 17 May 1916; and 4 September 1918.

45 Ibid., 12 June 1918.

${ }^{46}$ Ibid., 24 July 1918.

47 North Coast Power Company, Financial and Statistic Report, 1916-1920. 
${ }^{48}$ Clarke County Development Company, Petition for Abandonment, p. 4 .

${ }^{49}$ Columbian, 9 August; and 31 October 1918.

50 Public Service Commission, "North Coast Power Company," 20 December 1918.

${ }^{51}$ Ibid.

52 Ibid.

${ }^{53}$ Clarke County Development Company, Petition for Abandonment, p. 4 .

${ }^{54}$ Secretary of State, Session Laws of the State of Washington, Sixteenth Session, (Olympia, 1919), pp. 61-62.

55 Columbian, 22 March; 3 and 21 April 1919.

${ }^{56}$ Public Service Commission of Washington, "Vancouver Commercial Club, Complainant, vs North Coast Power Company, Respondent," 21 April 1919 , p. 6.

57 Ivan M. Wooley, M.D., "The 1918 'Spanish Influenza' Pandemic in Portland," Oregon Historical Quarterly 64 (September 1963), p. 249.

${ }^{58}$ Columbian, 6 November 1918.

${ }^{59}$ Ibid., 18 November 1918.

${ }^{60}$ Van Arsdol, "World War One," p. 82.

${ }^{61}$ Clarke County Development Company, Petition for Abandonment, p. 4 .

${ }^{62}$ Columbian, 2 June 1920.

63 Jones, The Consumer Society, p. 295.

${ }^{64}$ Clarke County Development Company, Petition for Abandonment, p. 4 . 
65 Ibid.

${ }^{66}$ Columbian, 19 August 1919.

${ }^{67}$ Ibid., 20 January 1920.

68 Ibid.

${ }^{69}$ Ibid., 3 August 1920.

$70_{\text {Ibid. }}$

${ }^{71}$ Ibid.

72 Ibid., 27 August 1920.

73 Ibid., 21 September 1920.

74 Ibid., 14 August 1919; 5 October; and 16 December 1920.

75 Ibid., 18 January 1923. 
CHAPTER IX

THE FINAL YEARS, $1923-1926$

The Puget Sound Power and Light Company engaged the services of a Boston based electrical engineering management firm, the Stone and Webster Corporation, to operate some of the utilities that it had purchased from the North Coast Power Company, including the street railway system in Vancouver. The Stone and Webster Corporation was one of the oldest such firms in this business and had been active in the Pacific Northwest for over twenty years. In 1900 it consolidated the eight small electric railways in Seattle into the Seattle Electric Company, and two years later acquired several railways in the Bellingham area. 1 The Vancouver street railway system demonstrated little promise of future profitability. The ridership was declining and the equipment was in poor condition: the cars were shabby, the track dilapidated, and the trolley wire was worn and would soon require replacement. 2

One of the most onerous problems that the new owners of the street railway faced (as had previous owners) was the paving required by the franchise. Twenty-sixth Street was in particularly poor shape and this was a source of friction between the company and city council. In March 1923, Mayor Nelson E. Allen told the company that the terms of the franchise, in regards to paving, must be followed, or that the franchise would be forfeited. According to the city engineer's estimate, it would cost about $\$ 22,000$ to pave along the tracks on this 
street. Richard M. Boykin, general manager for the street railway said that his company would prefer to tear up the track than to pay that amount. The water company (which was also owned by the Puget Sound Power and Light Company) announced that it would decide upon its special summer water rates after the council made its decision on the paving. After much discussion and negotiating, it was agreed to permit the street railway company to construct a curb along the cross ties and then firmly pack oiled gravel into the space between them. This was done at a cost of about $\$ 7,500$, a substantial savings for the company. ${ }^{3}$ By its willingness to compromise with the company, the city council indicated that Vancouver citizens wanted to retain their street railway, even if this meant assisting it in meeting its obligations.

Competition from other modes of travel continued to grow. By 1921 there were eighty-four miles of paved road in Clarke County, and automobiles, auto stages and buses were becoming more prevalent. A depot for the auto stages and buses was established at the corner of Third and Washington in 1921, and then shifted to Fifth and Main at the end of 1922. It had rest rooms, reading tables, lounge chairs, a tourist information booth, soda fountain, cigar store and three chair barber shop. ${ }^{4}$ The buses were quite luxurious when compared with earlier models. One that ran on the Portland - Vancouver - Camas route advertised that it had a "ladies compartment equipped with mirrors, plush seats, ice trays, ventilators, roll curtains, flower vases, and signal devices. $" 5$

In June 1924, it was announced that the Clarke County Development Corporation had been revived to manage the street railway. ${ }^{6}$ This firm 
which had been incorporated in 1909 to promote the Sifton area (see Chapter VI), had been inactive, though legally kept alive, for a number of years. Apparrently none of the original incorporators were still involved. At the year's end it was revealed that the Portland Electric Power Company, which until its reorganization in 1924 had been known as the Portland Railway Light and Power Company, had purchased the Vancouver street railway system from the Puget Sound Power and Light Company. At the same time it purchased the Vancouver water company, and a power and water system in Hillsboro, Oregon. The Clarke County Development Company would continue to mun the street railway, according to Portland Electric Power Company president Frank T. Griffith, "for as long a time as the street car is operated."?

Travel on the system had diminished in the previous two years, though not as rapidly as from 1920-1922. In 1923 the ridership was 480,067 , down 2.6 percent from 1922. On July 15, 1924, the city fare was raised from seven to ten cents and the ridership for that year dropped 3.2 percent to 464,599 , and in 1925 it was down another 9.5 percent. ${ }^{8}$ In five years the ridership had declined from over $1,000,000$ to 420,609 . Only twice during the past three years had the line been busy: the Prune Festival of 1923, and the Ku Klux Klan rally at Bagley Park in August 1924.9

The Vancouver citizens were aware of the problems that the line was experiencing and feared that they might lose it altogether. The Columbian blamed the high fare as the reason that the line was not better patronized, and suggested that "if the fare were lowered the number of passengers would increase in far greater proportion than the amount 
of the decrease in fares." 10 The company did not take the Columbian's advice, but the city agreed with the paper's view concerning municipal ownership of the street railway. The Columbian said that after Seattle's "disaster," the city should not consider taking over and operating it as a municipal line. ${ }^{11}$

The Portland Electric Power Company operated the line in the winter and spring of 1926. At the end of the summer, with dim prospects of the street railway ever producing a profit, it was decided to discontinue the system. In August the company applied to the Washington State Department of Public Works (formerly the Public Service Commission) for permission to terminate it, and a hearing was held on October 4 th in which citizens were given an opportunity to express their views on the proposed abandonment. 12

At the meeting, two merchants, one each from Sifton and Orchards, raised the strongest objections. They each had a feed store adjoining the railway tracks and were able to have their feed, primarily cracked corn, shipped directly to them from Portland at a cheap rate. This gave them a competitive advantage over other feed stores in nearby communities whose stock was delivered by truck. If the street railway was discontinued, the two merchants would lose their competitive advantage, and would have to reorient their stores to the roads. ${ }^{13}$

Another complaint raised against the abandonment of the line was that this was the way that many students living east of town traveled to high school in Vancouver. Without the street cars they would have to find other means of attending (such as riding in a dangerous "flivver") or, it was alleged, drop out of school. ${ }^{14}$ 
In its report, the Department of Public Works pointed out that the company had been incurring an annual loss since 1921, and that no evidence had been introduced by the public as to the public need for passenger service (except for the high school students). It did note that if service was discontinued, the store owners would have to reorient their stores and pay higher prices to have feed brought to them, but also pointed out that these stores already used trucks to deliver their merchandise. The commissioners conclusion was that "there appears no way in which the railway can recover the traffic which it formerly had," and said that according to the law, "a public utility cannot be compelled to continue public service at a loss."15 Therefore, the company was granted permission to abandon its line.

To allow the city line to establish a bus franchise, the street railway continued to operate. Then it began to abandon parts of its line. The final run to Sifton was made on October 11, and the Capitol Hill line ceased on the 31st. On November 8 the last street car ceased operation, and the buses commenced service. 16

The street car company suggested that it leave the tracks and trolley wire intact "as a favor to any other organization that might want to try operating street cars in Vancouver." ${ }^{17}$ The city council denied the company permission to do this, noting that since the company had made a failure of it, "no one else would have the temerity to attempt it soon."18 The council required the company to place a bitulithic covering on top of all the tracks on the paved streets, and remove them altogether from the others. All overhead apparatus was removed too. 19 
Vancouver's second street railway system had run for eighteen years and six weeks under several different names and owners. Although it had never attained its stated goal of 100 miles of track in the county (falling short by eighty-five miles), it had extended an interurban line to Sifton. Over ten million passenger rides had been given through the years. Now it was no more. 
NOTES FOR CHAPTER IX

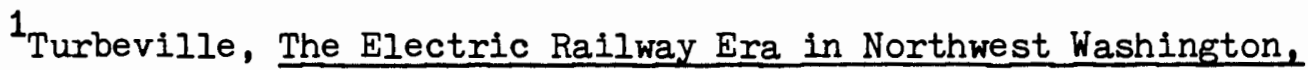
1890-1930, pp. 50-51.

2 Department of Public Works of Washington, "Transcript of Proceedings, Hearing Held at Vancouver, October 4, 1926, In re Application of the Clarke County Development Company for permission to discontinue electric railway operations between Vancouver and Sifton," p. 11. (hereafter cited as Department of Public Works, "Transcript of Hearing, October 4, 1926.")

${ }^{3}$ Columbian, 26 March; $14 \mathrm{July}$; and $1 \mathrm{June} 1923$.

${ }^{4}$ Ibid., 29 JuIy; 4 April 1921; 19 December 1922; and 26 January 1923.

5Ibid., 9 June 1921.

6 Ibid., 5 June 1924.

7 Ibid.

${ }^{8}$ See Clarke County Development Company, Petition for Abandonment, p. 4.; and Columbian, 18 July 1923.

${ }^{9}$ Clarke County Development Company, Financial Reports, May 1924December 1925, Puget Sound Power and Light Collection, University of Washington, August and September 1924.

${ }^{10}$ Columbian, 18 July 1923.

${ }^{11}$ Ibid.

12 Ibid., 20 August 1926.

13 Department of Public Works, "Transcript of Hearing, October 4, 1926," pp. 35-48.

${ }^{14}$ Columbian, 27 September 1926. 
${ }^{15}$ Department of Public Works of Washington, "Findings of Fact and Order, In the Matter of the discontinuance by the Clarke County Development Company of street railway service in Vancouver and between Vancouver and Sifton, Washington," October 9, 1926, p. 5.

${ }^{16}$ Columbian, 9 October; and 9 November 1926.

${ }^{17}$ Ibid., 1 September 1926.

${ }^{18}$ Ibid.

${ }^{19}$ Ibid. 
CHAPTER X

\section{VANCOUVER'S STREET RAIIWAYS: AN ASSESSMENT}

In examining the history of the Vancouver street railways, several questions are raised. Why were they built when and where they were? What led to their demise? What was their impact upon the city and county? And what was their legacy or effect?

The impetus to build the two systems was not because the backers belleved that the existing transportation needs would lead to a profitable street railway. In the case of the first system, with statehood imminent and business booming, the Columbia Land and Improvement Company decided in 1888 to build a line to their property on Vancouver Heights. This made it more accessible and, therefore, easier to sell. The primary objective was to sell real estate, not provide transportation. After the Spokane, Portland and Seattle Railroad had announced its plans in 1905, W.H. Moore sought and received a franchise for Vancouver's second street railway system. It was alleged that he was interested in getting the railway muning in order to sell it for a profit. Judging from the cheap construction of the system, this interpretation is likely correct.

The first system fell victim to the Panic of 1893. It had such a poor earnings record that it was not seen as worth saving; the receiver did not try to revive it. The second system, of course, lasted much longer. Its demise was a combination of the effect of automobiles and 
buses and need for some expensive repairs. Since it was not earning anything to speak of, and had little potential for an increase in revenues, its operation was suspended.

An examination of the factors that influenced the building, sales, and demise of the railway points to an observation: Vancouver citizens had little control over the railways. The Columbia Land and Improvement Company was composed of local men, and it was a group of Vancouver men that purchased Moore's Washington Railway and Power Company after his bank failed in 1907. The city council had some control over the street railways through the granting of franchises but once a company had a long-term franchise, the council had little leverage if the terms of the franchise were not met.

The events, decisions and trends that had the greatest effect on the street railway systems had their origins for from Vancouver. Examples of these outside developments are: statehood for Washington, the withdrawal of the Union Pacific in 1890, the Panic of 1893, the buildIng of the Spokane, Portland and Seattle Railroad (and its refusal to allow street cars on its Columbia River bridge), the recession in 1907 , the decisions of the Philadelphian financiers, permission from the War Department to build a line across the garrison, the role of the Vancouver Barracks in World War I, the shipbuilding industry, and the post-war recession. These all had major effects on the Vancouver street railway systems, usually indirectly through their effect upon the local economy. It is remarkable how little power the Vancouver citizens had to influence these factor.

Some aspects of the contemporary impact of the street railways on 
Vancouver are obvious. Transportation, both freight and passenger, was improved, improvements that aided the sale of real estate. And, as Vancouver citizens became accustomed to the service that the street cars provided, it increased their expectations about transportation. They would not be content to ride in a horse and buggy over bad roads after experiencing the speedy smooth ride that an electric street car traveling on rails could offer.

Most transportation networks develop in radial patterns. In Vancouver's case the central hub was Portland. Since the railway systems improved access to Portland, they tended to inhibit various cultural institutions, services and businesses in Vancouver; if these things were easily available in Portland, where they could serve a much larger population, there was no need for them in Vancouver. Instead of contributing to Vancouver's independence, the street railway systems tended to make the city a suburb of Portland.

A major effect of the street car systems was that they were a source of civic pride. Historian George M. Smerk asserts that at one time "no town or city worthy of the name could consider itself within the circle of moderm urbanized life if it was not served by a street railway."1 Popular historian Stewart Holbrook, recalling his arrival in the Pacific Northwest in the early 1920s, said

My own method of judging the comparative importance of places was... Did or did not the town have streetcars? The ones that did I automatically thought of as cities. All others were just villages.... The towns of Raymond and Chehalis, Washington [which had street railways], for instance, impressed me as being real, if small cities, while Bend, Oregon, with twice the population and probably twice the commerce and industry, was only a fine-looking village. 2

With a street railway, Vancouver had one of the hallmarks of a modern 
city.

The street railway had a major influence on the extension of the city boundaries in 1909 because of a state law regulating the fares within city limits. It was believed that new routes were to be built soon, and in order to insure a low fare a number of areas joined the city. This was not necessarily beneficial to Vancouver in the long run. A 1945 report by the city planning commission commented about the impact of the line built to the northeast of the city.

With this came an extension of the city boundary and an even more intense plague of unjustified subdivisions which disregarded every tenet of platting technique. A few isolated shacks were built among the stumps and brush that constituted a subdivision, but often before the streets were cleared of logs and other obstructions, the unpaid taxes had resulted in foreclosure and a transition had been made from raw land to a blighted area. Meanwhile, the comparatively few homes which more than met the minimal standards were sandwiched in among sheds, repair shops, shanties and garbage dumps.

These areas have improved considerably since the report was written, of course, but they are still not the fine residential and business districts that their promoters had promised, and their buyers had anticipated.

What is the legacy of the street railways in Vancouver? Is the city different as a result of them? Physically, not much is left to indicate that they ever existed. There are a few old houses in Vancouver Heights that appear to have been built at the time of the first system. Markle Avenue in southwest Vancouver was named after George $B$. Markle, the lgnominious owner of the first system. Of the later system, some tracks remain on Columbia Street between Sixth and Eighth. The southeast corner of Thirty-third and $K$ streets has a sweeping curve to it that was built to enable the cars to negotiate it smoothly and 
quickly. After the system ceased operation, the car barn at Thirtythird and St John Boulevard was used as a bus barn for many years. Now it houses an auto body shop. The trestle on Burnt Bridge Creek has long disappeared, but one can follow parts of the old right of way on Nicholson Road and N.E. Rosewood Avenue. In Orchards the feed store that was built alongside the railway tracks still stands. Kerr Avenue runs through Sifton; both community and street were named after principals of the Clarke County Development Company. Physical signs of the railway exist, but one has to look for them carefully.

Besides the meager physical evidence mentioned above, there is little today that indicates street cars once rambled through the streets of Vancouver. The reasons for this are clear upon consideration of the size of the system, the years of operation, and the history of the area's population growth. The first system was small and, except for the northernmost part of the line, went through a district that was already established. Since the line was short-lived (six years), its effect on shaping the city was small. Most of the route of the first system was included in the second one.

The street railway that began operation in 1908, and was extended to Sifton in 1910, was not considered a large system as it never exceeded fifteen miles of track. Had it reached the 100 miles that the company officials had promised, it would have had a strong influence on the settlement of the county. The line to Sifton paralleled Fourth Plain Road, which had been in use long before the railway. Consequently the railway only enhanced the development of that area.

Up to the time of the First World War the layout of most American 
cities was shaped by street railways. Since then the automobile has been the dominant force on the shaping of the cities. ${ }^{4}$ Most of the growth of Vancouver has occurred since the First World War. Between 1910 and 1950 the city more than quadrupled (from 9,300 to 41,449) and the county, including Vancouver, more than tripled (from 26,115 to $85,307) .^{5}$ Had this happened from 1890 to 1915 , for instance, while the street cars were operating, it is probable that the lines would have been extended and the legacy of the system could be observed in the shape of the city and county settlement patterns. As it is now, it is difficult to discern that Vancouver and Clark County ever had a street railway and interurban. 


\section{NOTES FOR CHAPTER $X$}

$1_{\text {George M. Smerk, "The Streetcar: Shaper of American Cities," }}$ Traffic Quarterly 21 (October 1967), p. 569.

${ }^{2}$ Stewart Holbrook, The Far Corner, (New York: 1952; Ballantine Books ed., 1973), pp. 95-96.

3 Vancouver City Planning Commission, Vancouver: Report to the Citizens and the City Commissioners, 1945, pp. 12-13.

${ }^{4}$ Smerk, "The Streetcar: Shaper of American Cities," p. 580.

5 Robinson, Washington State Statistical Abstract, pp. 16-17. 
SOURCES CONSULTED

\section{Primary Sources}

Company Records

University of Washington Library. Puget Sound Power and Light Collection. Clarke County Development Company. Financial Reports, May 1924-December 1925.

- Puget Sound Power and Light Collection. Clarke County Development Company. Petition in the Matter of Abandonment of Street Railway by the Clarke County Development Company, 1926.

- Puget Sound Power and Light Collection. North Coast Power Company. Financial and Statistic Report, 1916-1920.

- Puget Sound Power and Light Collection. Washington - Oregon Corporation. Minutes of the Board of Directors' Meetings, 19111915.

- Puget Sound Power and light Collection. Washington - Oregon Corporation. M.D. Spencer, Report on the Washington - Oregon and Independent Electric Company, 1914.

Western Washington University. Center for Pacific Northwest Studies. Puget Power Collection. Columbia Iand and Improvement Company. Ledger Number One, 1889-1899.

- Center for Pacific Northwest Studies. Puget Power Collection. Vancouver Traction Company. Distribution Record, 19091911.

- Center for Pacific Northwest Studies. Puget Power Collection. Vancouver Traction Company. Minutes of the Board of Directors' Meetings, 1908-1911.

Government Records

City of Vancouver

Vancouver City Council. Minutes of City Council Meetings.

- Ordinance Number 200. 5 February 1889. 
- Ordinance Number 288, 26 April 1892.

- Ordinance Number 289, 15 April 1892.

Vancouver City Planning Commission. Vancouver: Report to the Citizens and Commissioners, 1945.

Clark County

Clarke County Assessor. Tax Rolls of Real Property, 1894.

- Tax Rolls of Real Property, 1896.

Clarke County Auditor. Clarke County Development Company, Articles of Incorporation, 22 June 1909.

- Deeds and Mortgages, various volumes.

22 June 1909 .

- Vancouver Townsite Company, Articles of Incorporation,

11 November 1905.

- Vancouver Traction Company, Articles of Incorporation,

1 June 1908.

Washington State

Department of Public Works of Washington. "Findings of Fact and Order, In the Matter of the discontinuance by the Clarke County Development Company of Street railway service in Vancouver and between Vancouver and Sifton, Washington," 9 October 1926.

- "Transcript of Proceedings, Hearing Held at Vancouver, October 4, 1926, In re Application of the Clarke County Development Company for permission to discontinue electric railway operations between Vancouver and Sifton."

Public Service Commission of Washington. "The Public Service Commission of Washington ex rel C.H. Falk and Other Patrons, Complainant, vs North Coast Power Company, Respondant," 20 December 1918.

- "Vancouver Commercial Club, Complainant, vs North Coast Power Company, Respondent," 21 April 1919.

Secretary of State, Session Laws of the State of Washington, Sixteenth Session, 1919. 
United States

United States Army Corps of Engineers. Report of the Chief of Engineers, U.S. Army, 1910.

- Report of the Chief of Engineers, U.S. Army, 1914.

- Report of the Chief of Engineers, U.S. Army, 1917.

Newspapers

Clarke County Register, 22 September 1887 and 10 May 1888.

Daily Columbian (Vancouver), 1908-1926.

Independent (Vancouver), 1888-1910.

Oregonian (Portland), 9 July, 5 September 1888; 2 April 1910; and 28 November 1947.

Oregon Journal (Portland), 28 September 1913.

Portland Evening Telegram, 14 December 1917.

Tacoma News Tribune, 3 January 1927 and 2 January 1977.

Weekly Columbian, (Vancouver), 1906-1908.

Directories

Allen, Arthur H. Who's Who in Washington State. Vol 1. Seattle: Arthur H. Allen, pub., 1927.

Oregon and Washington Gazetteer and Business Directory. Seattle: R.I. Polk and Co., various dates.

Portland City Directory. Seattle: R.L. Polk and Co., various dates.

Vancouver City Directory. Seattle: R.I. Polk and Co., various dares.

\section{Correspondence}

Paul, Andrea I. Nebraska State Historical Society, Iincoln, Nebraska, Personal Letter, 19 July 1983. 
Unpublished Theses

Miller, James D. "Some Factors Affecting the Growth of Vancouver, Washington." M.A. thesis, Washington State College, Pullman, 1936.

Tattersall, James Neville. "The Economic Development of the Pacific Northwest." Ph.D. thesis, University of Washington, Seattle, 1960.

Throckmorton, Harold I. "The Interurbans of Portland, Oregon, A Historical Geography." M.A. thesis, University of Oregon, Eugene, 1962.

Secondary Sources

Books

Alley, B.F. and Munro-Fraser, J.P. The History of Clarke County, Washington Territory. Portland: The Washington Publishing Co., 1885.

Armstrong, Ellis L.; Robinson, Michael C.; and Hoy, Suellen M., eds. History of Public Works in the United States, 1726-1976. Chicago: American Public Works Association, 1976.

Athearn, Robert G. Union Pacific Country. New York: Rand McNally and Co., 1971.

Avery, Mary W. History and Government of the State of Washington. 1962 ed. Seattle: University of Washington Press, 1955.

Bancroft, Hubert Howe. History of Washington, Idaho and Montana. San Francisco: The History Co., 1890.

Cheever, Bruce. The Development of Railroads in the State of Washington, 1860-1948. Bellingham: Western Washington College of Education, 1949.

Cox, Thomas R. Mills and Markets, A History of the Pacific Coast Lumber Industry to 1900. Seattle: University of Washington Press, 1974.

Daggett, Stuart. Principles of Inland Transportation. New York: Harper and Bros., 1928.

Faulkner, Harold U. The Decline of Laissez Faire, 1897-1917. New York: Holt, Rhinehart and Winston, 1951; reprint ed., Harper Torchbook, 1968

- Politics, Reform and Expansion, 1890-1930. New York: Harper and Bros., 1959; reprint ed., Harper Torchbook, 1963. 
Fogelson, Robert M. The Fragmented Metropolis: Los Angeles, 1850-1930. Cambridge: Harvard University Press, 1967.

Foster, Mark S. From Streetcar to Superhighway: American City Planners and Urban Transportation, 1900-1940. Philadelphia: Temple University Press, 1981.

Gill, Frank B. An Unfinished History of Transportation in Oregon and Washington. n.p., 1914-1920.

Hilton, George W., and Due, John F. The Electric Interurban Railways in America. Stanford: Stanford University Press, 1960.

Hines, H.K. An Illustrated History of the State of Oregon. Chicago: The Lewis Publishing Co., 1893.

Hitchman, James H. The Port of Bellingham, 19201970. Occasional Paper no. 1. Bellingham: Center for Pacific Northwest Studies, Western Washington State College, 1972.

Holbrook, Stewart H. The Far Corner. New York:, 1952; Ballantine Books ed., 1973.

Johansen, Dorothy $0 .$, and Gates, Charles. Empire of the Columbia. 2nd ed. New York: Harper and Row, 1967.

Jones, Peter d'Alroy. The Consumer Society, A History of American Capialism. London: Penguin Books, 1965; rev, ed. of America's Wealth. New York: Macmillan Co., 1963.

Labbe, John T. Fares, Please! Those Portland Trolley Years. Caldwell, Idaho: Caxton Printers, 1980.

Lockley, Fred. History of the Columbia River Valley, Deluxe Supplement. Chicago: The S.J. Clarke Publishing Co., 1928.

McArthur, Lewis A. Oregon Geographic Names. 2nd. ed. Portland: Binfords and Mort, 1944.

MacColl, E. Kimbark. The Growth of a City: Power and Politics in Portland, 1915-1950. Portland: The Georgian Press Co., 1979.

- The Shaping of a City: Business and Politics in Portland, 1885-1915. Portland: The Georgian Press Co., 1976.

Modjeski, Ralph. The Vancouver - Portland Bridges: A Report to Mr. Howard EIliott, President of the Northern Pacific Company, and to Mr. John F. Stevens, President of the Spokane, Portland and Seattle Railway Company. Chicago: H.L. Sherman and Co., 1910.

Newell, Gordon, ed. The H.W. McCurdy Marine History of the Pacific Northwest. Seattle: Superior Publishing Co., 1966 
Pollard, Lancaster. A History of the State of Washington. 4 vols. New York: The American Historical Society, 1937.

Richmond, Henry III. The History of the Portland District, Corps of Engineers, 1871-1969. U.S. Corps of Engineers, 1970.

Robinson, Marilyn Druck. Washington State Statistical Abstract. Seattle: University of Washington Press, 1952.

Rowsome, Frank Jr. Trolley Car Treasury. New York: Bonanza Books, 1956.

Shaver, F.A., comp. An Illustrated History of Central Oregon. Spokane: Western Historical Publishing Co., 1905.

Turbeville, Daniel E., III. The Electric Railway Era in Northwest Washington 1890-1920. Occasional Paper no. 12. Bellingham: Center for Pacific Northwest Studies, Western Washington University, 1979.

Warner, Sam B., Jr. Streetcar Suburbs: The Process of Growth in Boston, 1870-1900. Cambridge: Harvard University Press, 1962.

Wood, Charles R. Spokane, Portland and Seattle Railway, The Northwest's Owm Railway. Seattle: Superior Publishing Co., 1974.

Articles

Barrett, Paul. "Public Policy and Private Choice: Mass Transit and the Automobile in Chicago between the Wars." Business History Review 49 (Winter 1975): 473-479.

Bona, Milton. "Fiat Lux: Electricity in Clark County." Clark County History Annual 20 (1979): 4-25.

- "Louis Sohns Came to County with Grant." Clark County History Annual 17 (1976): 44-51.

Brown Estella Dee. "Some Activities of the Corps of Engineers in Oregon, 1866-1890." Reed College Bulletin vol. 31 no. 5 (August 1953): $25-46$.

Brownell, Blaine A. "The Notorious Jitney and the Urban Transportation Crisis in Birmingham in the 1920s." Alabama Review 25 (April 1972): 105-118.

- "A Symbol of Modernity: Attitudes Toward the Automobile in Southerm Cities in the 1920s." American Quarterly 24 (March 1972): $20-44$.

Carlson, Dorothy, "Vancouver's First Race Track." Clark County History Annual 15 (1974): 382-390. 
Dewees, Donald N. "The Decline of American Street Railways." Traffic Quarterly 24 (October 1970): 563-581.

DuBois, Don. "DuBois and Sons." Clark County History Annual 24 (1983): 38-59.

Foster, Mark S. "City Planners and Urban Transportation: The American Response, 1900-1940." Joumal of Urban History 5 (May 1979): 365-396.

- "The Model-T, the Hard Sell, and Los Angeles's Urban Growth: The Decentralization of Los Angeles during the 1920s." Pacific Historical Review 64 (November 1975): 459-484.

- "The Westem Response to Urban Transportation, 1900-1940: A Tale of Three Cities, 1900-1945." Journal of the West 18 (July 1979): 31-39.

Gates, Charles M. "A Historical Sketch of the Economic Development of Washington since Statehood." Pacific Northwest Quarterly 39 (July 1948): 214-232.

Jones, Roy F. "The Name Was Hidden." Clark County History Annual $?$ (1966): 155-172.

Mills, Randall V. "Early Electric Interurbans in Oregon. 1. Forming the Portland Railway Light and Power System." Oregon Historical Quarterly 44 (March 1943): 82-104.

- "Early Electric Interurbans in Oregon. 2. The Oregon Electric and Southern Pacific Systems." Oregon Historical Quarterly 44 (December 1943): 386-410.

Purdy, Harry Leslie. "The Cost of Municipal Operation of the Seattle Street Railway." University of Washington Publications in the Social Sciences 8 (1929-1939): 1-28.

Rae, John B. "The Evolution of the Motor Bus as a Transport Mode." High Speed Ground Transportation Joumal 5 (Summer 1971): 221-235.

Ransom, Victoria L. "Officers' Row at Vancouver Barracks." Glark County History Annual 3 (1962): 38-43.

Smerk, George M. "The Streetcar: Shaper of American Cities." Traffic Quarterly 21 (October 1967): 569-584.

Van Arsdol. "World War One Brought Boom Times." Clark County History Annual 17 (1976): 53-87.

West Shore, February 1889. 
Wooley, Ivan., M.D. 'The 1918 'Spanish Influenza' Pandemic in Portland." Oregon Historical Quarterly 64 (September 1963): 246-258. 